Andrews University

Digital Commons @ Andrews University

1988

\title{
A Study For Educational Administrators Concerning The Relationships Between Selected Dimensions Of Christian Education And Student Spirituality In Seventh-Day Adventist Day Academies In The United States Of America
}

Bruce R. Youlden

Andrews University

Follow this and additional works at: https://digitalcommons.andrews.edu/dissertations

Part of the Religion Commons, and the Secondary Education Commons

\section{Recommended Citation}

Youlden, Bruce R., "A Study For Educational Administrators Concerning The Relationships Between Selected Dimensions Of Christian Education And Student Spirituality In Seventh-Day Adventist Day Academies In The United States Of America" (1988). Dissertations. 1568.

https://digitalcommons.andrews.edu/dissertations/1568

https://dx.doi.org/10.32597/dissertations/1568

This Dissertation is brought to you for free and open access by the Graduate Research at Digital Commons @ Andrews University. It has been accepted for inclusion in Dissertations by an authorized administrator of Digital Commons@ Andrews University. For more information, please contact repository@andrews.edu. 


\section{INFORMATION TO USERS}

The most advanced technology has been used to photograph and reproduce this manuscript from the microfilm master. UMI films the text directly from the original or copy submitted. Thus, some thesis and dissertation copies are in typewriter face, while others may be from any type of computer printer.

The quality of this reproduction is dependent upon the quality of the copy submitted. Broken or indistinct print, colored or poor quality illustrations and photographs, print bleedthrough, substandard margins, and improper alignment can adversely affect reproduction.

In the unlikely event that the author did not send UMI a complete manuscript and there are missing pages, these will be noted. Also, if unauthorized copyright material had to be removed, a note will indicate the deletion.

Oversize materials (e.g., maps, drawings, charts) are reproduced by sectioning the original, beginning at the upper left-haind corner and continuing from left to right in equal sections with small overlaps. Each original is also photographed in one exposure and is included in reduced form at the back of the book. These are also available as one exposure on a standard 35mm slide or as a 17" $x 23$ " black and white photographic print for an additional charge.

Photographs included in the originai manuscript have been reproduced xerographically in this copy. Higher quality $6^{\prime \prime} \times 9^{\prime \prime}$ black and white photographic prints are available for any photographs or illustrations appearing in this copy for an additional charge. Contact UMI directly to order.

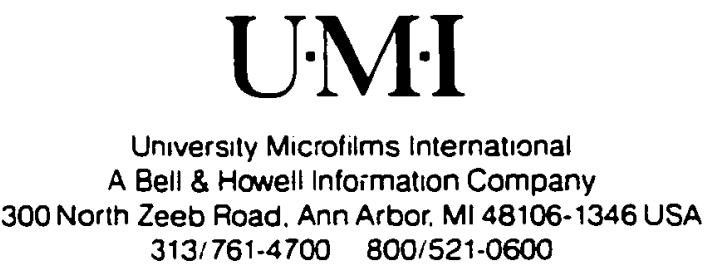


Order Number 8907854

A study for educational administrators concerning the relationships between selected dimensions of Christian education and student spirituality in Seventh-day Adventist day academies in the United States of America

Youlden, Bruce Robert, Ph.D.

Andrews University, 1988

Copyright (C1988 by Youlden, Bruce Robert. All rights reserved.

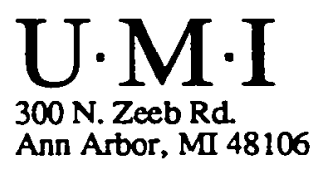


andrews University

School of Education

\title{
A STUDY FOR EDUCATIONAL ADMINISTRATORS CONCERNING THE RELATIONSHIPS BETWEEN SELECTED DIMENSIONS OE CHRISTIAN EDUCATION AND STUDENT SPIRITUALITY IN SEVENTH-DAY ADVENTIST DAY ACADEMIES IN THE UNITED STATES OF AMERICA
}

\author{
A Dissertation \\ Presented in Partial Fulfillment \\ of the Requirements for the Degree \\ Doctor of Philosophy
}

by

Bruce R. Youlden

May 1988 
A STUDY FOR EDUCATIONAL ADMINISTRATORS CONCERNING THE

RELATIONSHIPS BETWEEN SELECTED DIMENSIONS OE

CHRISTIAN EDUCATION AND STUDENT SPIRITUALITY

IN SEVENTH-DAY ADVENTIST DAY ACADEMIES

IN THE UNITED STATES

A Dissertation

Presented in Partial Fulfillment

of the Requirements for the Degree

Doctor of Philosophy

by

Bruce R. Youlden

APPROVAL BY THE COMMITTEE:

Co-chairman:

Roy C. Naden

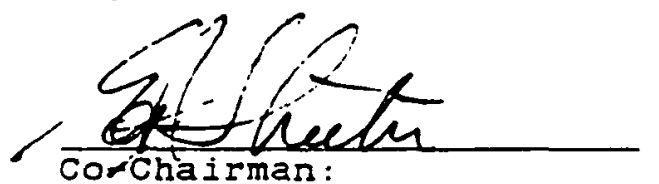

Edward A. Streeter

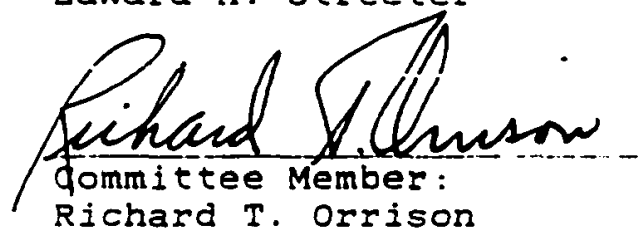

Richard $T$. Orrison

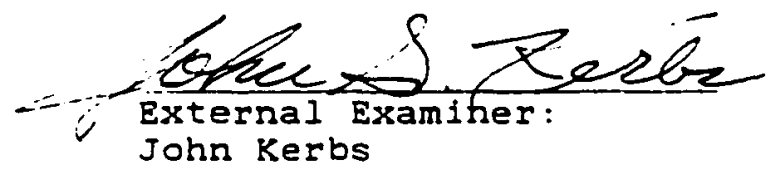

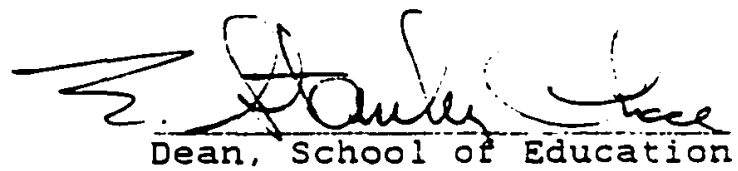

E. Stanley Chace 
C Copyright by B. R. Youlden 1988

All Rights Reserved 


\title{
ABSTRACT
}

A STUDY EOR EDUCATIONAL ADMINISTRATORS CONCERNING THE RELATIONSHIPS BETWEEN SELECTED DIMENSIONS OF CHRISTIAN EDUCATION AND STUDENT SPIRITUALITY IN SEVENTH-DAY ADVENTIST DAY ACADEMIES IN THE UNITED STATES OF AMERICA

\author{
by \\ Bruce R. Youlden \\ Co-Chairmen: RoY C. Naden, Ed.D. \\ Edward A. Streeter, Ed.D.
}




\title{
ABSTRACT OF GRADUATE STUDENT RESEARCH \\ Dissertation
}

\author{
Andrews University \\ School of Education
}

\section{Title: A STUDY FOR EDUCATIONAL ADMINISTRATORS CONCERNING THE RELATIONSHIPS BETWEEN SELECTED DIMENSIONS OF CHRISTIAN EDUCATION AND STUDENT SPIRITUALITY IN SEVENTH-DAY ADVENTIST DAY ACADEMIES \\ IN THE UNITED STATES OF AMERICA}

Kesearcher: Bruce R. Youlden

Advisors: Roy C. Naden, Ed.D.

Edward A. Streeter, Ed.D.

Completed: May, 1988

\section{Problem}

Central to Christian education are the twin goals

of leading students into a personal relationship with christ and nurturing student spirituality. Yet, while the importance of these goals were generally recognized by Christian educators, the dimensions of Christian education which have greatest impact on adolescent spirituality were not identified. 
Therefore, the purpose of this study was to research (1) possible differences in the levels of student spirituality between Seventh-day Adventist day academies in the United States, (2) possible differences in the levels of spiritual nurture in selected dimensions of Christian education (3) possible relationships between the selected dimensions of Christian education and student spirituality, and (4) educational administrative implications for enhancing student spirituality in Christian schools.

\section{Method}

Seventh-day Adventist day academies in the united States constituted the population from which a sample of 20 schools was randomly selected. Two Likert type attitudinal scales, the Spirituality Inventory (SI) and the Spiritual Nurture Inventory (SNI), were developed for the study. The reliability coefficient for the SI scale was .9343 and for the SNI scale .9222. The statistical analyses employed to test the three hypotheses included analysis of variance and muitiple-regression.

\section{Results}

of the 20 day academies and 753 seniors selected, 19 day academies and 591 seniors returned the SI and the SNI for analysis.

In response to Hypothesis 1 and 2 , statistically significant differences were found in the levels of student spirituality and in the levels of spiritual nurture in 
Seventh-day Adventist day academies in the United States at a $p<.05$. In response to Hypothesis 3 , statistically significant relationships were found between the selected dimensions of spiritual nurture and both "student" and "school" spirituality in Seventh-day Adventist day academies in the United States at a $p<.05$.

\section{Eindines}

On the basis of the data collected in seventh-day Adventist day academies in the United States, the major findings are summarized:

1. There were small differences in the levels of student spirituality between schools, although, overall levels of student spirituality were moderately high.

2. There were large differences in the levels of spiritual nurture both "between" and "within" sshools.

3. Students perceived that School Worships, Weeks of Prayer, Bible Classes and the Bible Teacher, School Curriculum, and the Home Environment had the greatest impact on "student spirituality" and/or "school spirituality."

4. The Bible Class, Week of Prayer, Home Environment, and School Curriculum were found to be the major predictors of higher levels of "student spirituality" and/or "school spirituality." 


\title{
Dedicated
}

\author{
to Him who loves me and gave Himself for me \\ to my loving and beloved parents \\ to Geoff and Lynn. Margaret and Ian \\ and \\ to my closest friend and companion, Anne-Marie
}


TABLE OF CONTENTS

IIST OE TABLES . . . . . . . . . . . . . . . . . . . vii

ACKNOWLEDGMENTS . . . . . . . . . . . . . . . . . . . viii

Chapter

I. INTRODUCTION . . . . . . . . . . . . . . . . . . 1

Background of the Study . . . . . . . . . . . . 4

Statement of the Problem . . . . . . . . . . . 8

Furpose of the study . . . . . . . . . . . . . 9

Importance of the Study . . . . . . . . . . . . 10

Hypotheses . . . . . . . . . . . . . . . . . . 11

Definition of Terms . . . . . . . . . . . . . . 11

Delimitations... . . . . . . . . . . . . . . 12

Assumptions . . . . . . . . . . . . . . . . . . 13

organization of the study. . . . . . . . . . . 13

II. REVIEW OF LITERATURE . . . . . . . . . . . . . . 15

Introduction . . . . . . . . . . . . . . . . . 15

Dimensions of Christian Spirituality . . . . . 17

Christian Spirituality . . . . . . . . . . . 17

Meditation . . . . . . . . . . . . . . . 19

Prayer . . . . . . . . . . . . . . . . 23

Study . . . . . . . . . . . . . . . . . 26

Confession . . . . . . . . . . . . . . . . . 29

Solitude . . . . . . . . . . . . . . . . . 32

Submission . . . . . . . . . . . . . . . . 35

Service... . . . . . . . . . . . . . . 38

Worship Celebration. . . . . . . . . . . . . 42

Guidance . . . . . . . . . . . . . . . . 45

Joyfulness . . . . . . . . . . . . . . . . . 48

Dimensions of Student Spiritual Nurture. . . . 51

Spiritual Nurture . . . . . . . . . . . . . . 51

Principal Splrituality . . . . . . . . . . . 52

School Curriculum .. . . . . . . . . . . . . 59

Teaching Methodology . . . . . . . . . . . . 64

School Discipline . . . . . . . . . . . . . . 69

Teacher Spirituality . . . . . . . . . . . . 75

School Worships...... . . . . . . . . . . 80

Community Service Outreach . . . . . . . . 83

Bible Teacher Splrituality . . . . . . . . . 88

iv

Reproduced with permission of the copyright owner. Further reproduction prohibited without permission. 
Weeks of Prayer/Spiritual Emphasis . . . . . 93

Bible Classes . . . . . . . . . . . . . . . 98

Summary . . . . . . . . . . . . . . . 102

III. METHODOLOGY . . . . . . . . . . . . . . 105

Population and Sample. . . . . . . . . . . . 105

Instrumentation . . . . . . . . . . . . . . . $10 \epsilon$

Instrument Development Procedures... . . . . 106

Data Collection Procedure . . . . . . . . . . . 116

Statistical Analyses . . . . . . . . . . . . . 118

Summary . . . . . . . . . . . . . . . . . . 118

IV. RESULTS . . . . . . . . . . . . . . . . . . . . . 120

Differences in the Levels of Spirituality and in the Levels of Spiritual Nurture in Seventh-day Adventist Day Academies in the United States . 120 Relationships between Spirituality and

Spiritual Nurture in Christian Education . . . 127

Relationships between student spirituality

(SI Scores) and student Perceptions of

Spiritual Nurture (SNI Scores) . . . . . . . 129

Relationships between student spirituality

(SI Scores) School Spiritual Nurture

(SNI Means). . . . . . . . . . . . . . . . . 135

Relationship between School Spirituality

(SI Means) and School Spiritual Nurture

(SNI Means) . . . . . . . . . . . . . . . . . 136

Implications for Educational Administrators. . i47

Principal Spirituality . . . . . . . . . . . 147

School Curriculum . . . . . . . . . . . . . . 148

Teaching Methodology . . . . . . . . . . . . 149

School Discinline. . . . . . . . . . . . . . 150

Teacher Spirituality . . . . . . . . . . . . 150

School Worships... . . . . . . . . . . . . 151

Community Service Outreach . . . . . . . . . 152

Bible Teacher Spirituality . . . . . . . . . 153

Weeks of Prayer/Spiritual Emphasis . . . . . 154

Bible Classes . . . . . . . . . . . . . . . 155

Home Environmental Influence . . . . . . . . 156

Summary.................... . . 157

V. SUMMARY, FINDINGS, IMPLICATIONS,
AND RECOMMENDATIONS . . . . . . . . . . . . . 160

Summary . . . . . . . . . . . . . . . . . 160

Findings . . . . . . . . . . . . . . . . . . . 163

Discussion and Implications . . . . . . . . . . 165

Recommendations.................. . 172

For Further Research . . . . . . . . . . . . 172

v 


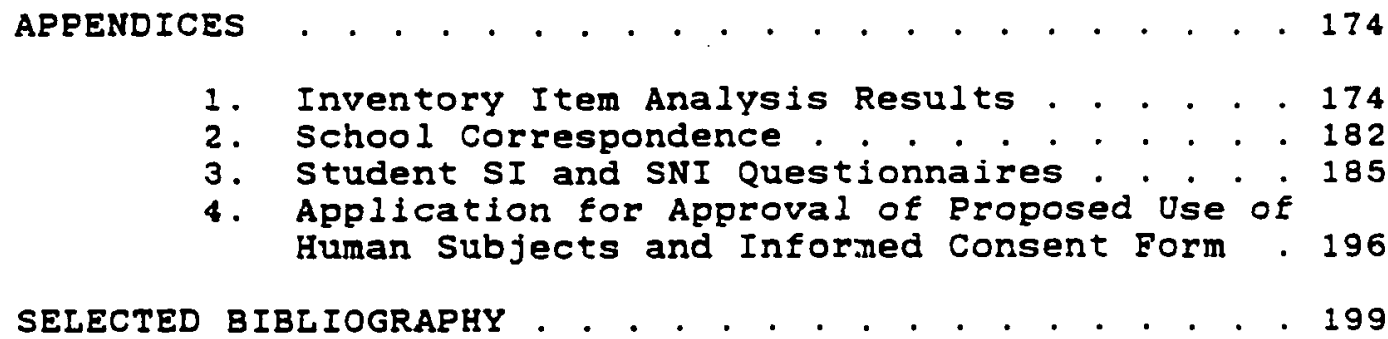

vi

Reproduced with permission of the copyright owner. Further reproduction prohibited without permission. 


\section{LIST OF TABLES}

1. SI Construct. . . . . . . . . . . . . . 107

2. SNI Construct . . . . . . . . . . . . . 107

3. SNI Reliability Coefficients . . . . . . . . . . . 112

4. SI Item Welght Analysis . . . . . . . . . . . . . 114

5. SNI Item Weight Analysis. . . . . . . . . . . . . 114

6. SI Factor Analysis Results . . . . . . . . . . . 115

7. SI Stepwise Regression Summary Table . . . . . . . 115

8. A Three Dimension SI . . . . . . . . . . . . . 117

9. Table of SI and SNI Means by Rank order . . . . . 121

10. Boxplots of SNI Means . . . . . . . . . . . . . . 124

11. Table of SI and SNI Means by School order . . . . 126

12. Correlation Between Student SI Scores and Student SNI Scores.. . . . . . . . . . . . . . . . . . . 130

13. Student Spirituality Stepwise Selection Using
Student SNI Scores. . . . . . . . . . . . . . 132

14. Unique Contribution of Variables in Model . . . . 134

15. Correlation Between School SI Means and School
SNI Means ........................... 137

16. School Spirituality Stepwise Selection Using
School SNI Means....... . . . . . . . . . . 140

17. Unique Contribution of Variables in Model . . . . 140

18. School Spirituality Backward Selection Using

School SNI Means... . . . . . . . . . . . . . . 141

19. Unique Contribution of Variables in Model . . . . 143

20. Summary Table of Selected Prediction Models . . 145

vii 


\section{ACKNOWLEDGMENTS}

I am indebted to and truly grateful for the inspiration, guidance, and assistance given by Dr. Roy Naden whose dedication to quality work, efficiency, articulation, and personal commitment have contributed significantly to my personal and professional growth.

I am grateful for the counsel, assistance, and accessibility provided by Dr. Edward Streeter whose helpfulness and cooperation were greatly appreciated.

I am appreciative of the helpful assistance provided by Andrews Academy principal Dr. Richard orrison whose school is a model of Christian education.

I am most grateful for the considerable and willing assistance of Dr. Jerry Thayer whose accessibility and commitment to quality research is an inspiration.

I would like to acknowledge the helpful guidance of Dr. Merle Greenway and for the editorial assistance of Ms. Joyce Jones.

I wish to acknowledge the scholarship of Dr. George Akers whose 1980 seminars in Australia provided the inspiration of what Christian education might become and how Christian educators might enhance the spiritual lives of students. 


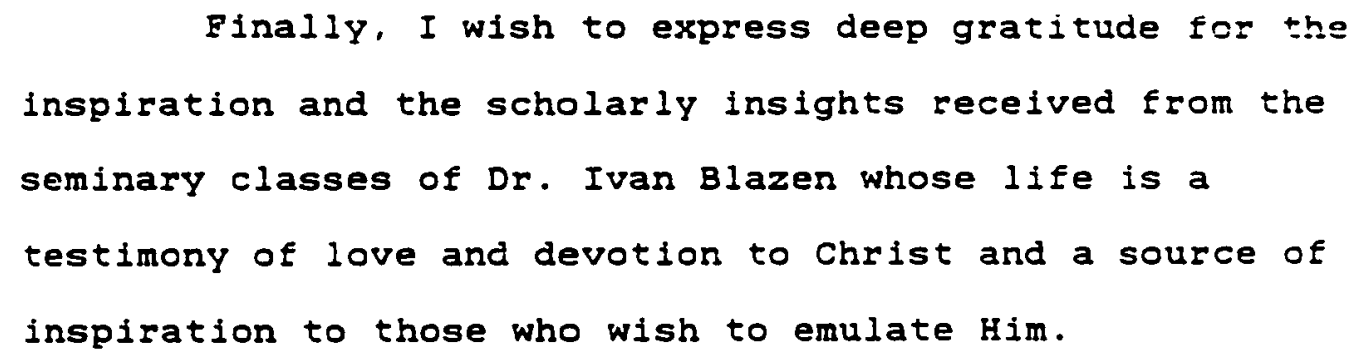


CHAPTER I

INTRODUCTION

This chapter provides an introduction and background to the study, a statement of the problem, purposes and importance of the study, the operational hypotheses, and definition of terms. Also included are the delimitations, assumptions, and an organizational outline of the study.

Central to Christian education are the twin goals of leading students into a personal relationship with Christ and nurturing student spirituality. Consequently. one of the most important responsibilities for Christian educational administrators is the need to provide leadership which fosters that spirituality in all areas of the educational program. As a response to this challenge, this study attempted to identify from selected dimensions of Christian education those which are most closely related to higher levels of student spirituality.

created in the image of God, humanity once stood in harmony with the Maker. However, through the fall of mankind. the image of God and the intimate relationship 
with the Creator, while not totally destroyed, were grossly distorted. Knight (1980, p. 183) suggested that

If the entrance of sin brought alienation and the deterioration of relationships, then the essence of the gospel is to rebuild those relationships. The entire process entalis a restoration of the image of God in man through the agency of the Holy Spirit. Education is one arm of God's restorative - ffort and may therefore be seen as a redemptive activity.

It seems that the responsibility of the Christian school is to unite with the home and the church in God's restorative work for each individual. The task for the christian educator is to assist parents in the responsibility of leading young people into a personal relationship with Jesus and to nurture spiritual growth (Cummings, 1979. pp. 1, 6). In this respect, the goals of the home, school, and church are one.

In a mafor study of spiritual nurture, Rumer (1967, p. 2) expressed concern over the lack of correlation between attempts by educators to communicate Christian faith and student spirituality. As a result, he proposed the theory tizat "Christian Education is Spiritual Nurture." He explained:

Christian nurture is the attempt by human educators to correlate the spiritual demands of the learner with the self-disclosure of God and his intentions for man; to correlate also God's claims upon the spiritual capacities of the learner with his responses of falth and love. Christian nurture is a way of proclaiming the gospel to men (and children and youth) in their condition or situation and of presenting its inherent claim to their response of falth and love. (p. 323) 
To nurture and enhance student spirituality, according to Alexander $(1972)$, it is first necessary for educators to recognize the importance of their partnership with the Holy Spirit. He stated that "the Holy Spirit is the Author and continuing Source of all the valid spirituality we can know or have" (p. 28). It would seem, therefore, that the power and influence of the Holy Spirit is a crucial element in spiritual nurture. Wessler $(1980$. p. 2) argued that Christian schools are distinctive when they anticipate the power of the Word and the spirit of God to change lives. He suggested that the task is to claim and harness that power and to anticipate the results of divine intervention.

To nurture and enhance student spirituaijty, it is also necessary for educators to recognize that the centra! focus of all spiritual nurture should be Jesus Christ. According to Shelton (1983, p. 9), the nurturling process should focus on the personal invitation of Christ to "come, follow me," and "walk the path of Jesus," while helping students realize "what journeying with Jesus really means." Chadwick (1982, pp. 41-42) also suggested that an essential prerequisite for nurturing spirituality in another person is the necessity for the nurturer to be dynamically related to Jesus Christ. He argued that the effectiveness of spiritual nurture is substantially a function of the nurturer's personal spirituality. 
The objective of the nurturing process, according to Byrne (1977, p. 107), Is to help students to reflect the character of Christ more fully. Simllarly, Chadwick (1982, p. 36) suggested that "the ultimate test of Christian education is not just academic excellence, but rather character change and Christlikeness." Patt (1975, p. 6) added :

Character training (via the acquisition of a Christian value system) is more tinan an objective of education. It is the heart of education, the essential meaning of education. Nothing else in education or this life is worth having without a well-developed character.

The result of fostering Christian character is discipleship and a commitment to lead others into a similar relationship with Christ (Gangel \& Benson, 1983, p. 77 , Graendorf, 1981, p. 11). In this respect, scott (1985, p. 37) suggested that

Christian education. . . exists to carry out two related functions: evangelism (to make disciples) and edification (to nurture disciples and equip them for ministry) (Matt. 28:19-20; Eph. 4:10-12). This means that the goal of Christian education is mature Christians, not simply converts (Col. 1:28$29 ; 2: 7)$. In other words, Christian education is discipleship.

\section{Background of the study}

This research was the outgrowth of a personal and professional quest to understand more fully the nature of spirituality, how it may become a personal reality, and how, as a Christian educational administrator, one may lead students into a similar personal encounter with Christ. 
While great progress has been made toward meeting the goals of Christian education, there still remains much work to be done in the area of spiritual nurture. Gaebeleis (1968, pp. 14-16) believed

A good many Christian institutions are unconsciously deceiving themselves. . . As for many evangelicai schools and colleges, because they have daily chapel services, Bible departments, and flourishing student activities of a Christian nature, they conclude that they are Christcentered, Bible-based institutions, when in reality they have not yet grown up to that stature.

Theory, research, and practice suggest that students' spiricual nurture has been inhibited by the existence of a number of misconceptions. Eirst, it has been suggested that there is a low correlation between philosophy and practice. While Christian philosophy is readily espoused by most Christian educators, there appear to be inadequacies both in the stated philosophies as well as in translating them into educational practice. Accordingly, knight (1980, pp. 142, 178) maintained that a major area of need is the clarification of Christian school philosophy. He argued that

All too often Christian education has not been deliberately built upon a distinctive Christian philosophy. As a result, many Christian schools have tended to offer something less than Christian education and have thus frustrated the purpose of their existence. . .

Chadwick (1982, p. 168) agreed with this view and added.

Many schools have not taken the time to adequately think through the Christian philosophy of education, and as a result have for all practical purposes developed an educational philosophy that simply has a veneer of Christianity. 
A second factor inhibiting student spiritual nurture ss the low priority given to it in the school program and a frequent failure to recognize the role of the Holy spirit in spiritual growth. According to Alexander (1981, p. 307),

We live in an age which, at best, ignores the importance of human spirituality, offering no guidance to the young (and old) as to how to direct and control the powerful innerpassions of humankind.

Stone (1985, p. 97) suggested that many youth groups fall because priority is not given to spiritual growth. Rather, other activities and interests are often seen to crowd out the "things of God." He added that not only should priority be given to spiritual nurture but every aspect of the program "needs to be planned with spiritual growth in mind."

Christian educators often fall to recognize the role of the Holy Spirit in spiritual growth. According to Alexasder (1972, p. 28), Christian community on campus is not a corporate or personal dream to be realized so educators can feel they are meeting the spiritual needs of students. Rather, it is a reality already befing created by the Spirit of God in which educators may participate. A third factor inhibiting the nurturing process is the misconception concerning adolescent spiritual development. Erequently theologians and educators have assumed "a static view of human nature, as though persons were born as adults" (Rumer, p. 80). This has been evident 
in the area of spirituality. Shelton (1983, p. viii) suggested that

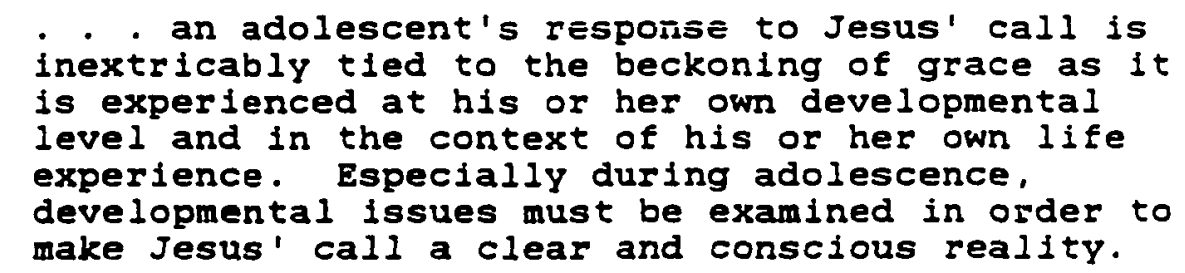

It is also frequently thought that, with the observable decline in traditional beliefs and practices among adolescents, there is a similar decline in tha tesire for spiritual growth. To the contrary. Shelton (1983, p. 8) observed that adolescents search for deeper answers and meanings for their lives. He suggested that they place great importance on a relationship with God. On the basis of a 1980 Gallup Poll, it was suggested that adolescents wanted to go into the "deep places" of God through prayer, Bible study, and personal discipline. They wanted to know how to build a spiritual life (Stone, 1985. pp. 11,20$)$.

Another related problem is that the impact of the spiritual dimension upon personality development is often perceived as negligible. In an extensive study into the spiritual nature of the learning person, Rumer (1968, p. 203) suggested that "the development of the spirituai dimension is the most important aspect of personality development." He argued that relationships with self, others, and God are dependent upon it. He maintained that 
2

The way each person travels the path of spiritual development determines the kind of person he is becoming. In turn, what each particular person is becoming depends on his spiritual learning along the path of development. (p. 214)

A fourth factor inhibiting the spiritual nurture process is the shortage of models of spiritual vitality among Christian educators. In a study of why teenagers reject religion. Dudley (1978, p. 80) stated: "ro uther factor was as strongly related to teen-age rejection of religion as was the religious insincerity of their academy teachers." White (1952, p. 259) stated:

It is because so many parents and teachers profess to believe the word of God while their lives deny its power, that the teaching of scripture has no greater effect upon the youth.

With these four factors as a background, the need for the study becomes more apparent. As notable as the achievements in Christian education have been, there is still much to be accomplished in order to realize more fully the goal of enhancing student spirituality (Gaebelein, 1968, p. 14).

\section{Statement of the Problem}

Central to Christian education are the twin goals of leading students into a personal relationship with Christ and nurturing student spirituality. Yet, while the importance of these goals were generally recognized by Christian educators, the dimensions of Christian education which have greatest impact on student spirituality were not identified. 


\section{Purpose of the study}

The purpose of this study was to identify from selected dimensions of Christian education those which are most closely related to higher levels of student spirituality. Specifically, the study attempted to:

1. Identify from the writings of the spiritual masters of the Christian church the dimensions considered fundamental to Christian spirituality.

2. Identify from the writings of Christian education theorists the dimensions of christian education considered fundamental to nurturing student snirituality.

3. Develop an empirical scale to determine the perceived level of student spirituality in seventh-day Adventist day academies in the United States.

4. Develop an empirical scale to determine the relative effectiveness of the dimensions of Christian education in nurturing student spirituality.

5. Discover the perceived levels of student spirituality in 20 randomly selected Seventh-day Adventist academies in the United States.

6. Discover the levels of spiritual nurture in 20 randomly selected Seventh-day Adventist day academies in the United States.

7. Discover which dimensions of Christian education studied are most closely related to higher levels of student spirituality. 
8. Discuss the educational administrative impiications for enhancing student spirituality in Christian schools.

\section{Importance of the study}

There are four reasons why this study is important for Christian education. First, it addresses an issue that ought to be of fundamental interest to all Christian educators who feel called to lead students into a meaningful relationship with Jesus Christ.

Second, while the goal of Christian education is to enhance student spirituality, there is no known study that has identified those dimensions of Christian education which are most closely related to higher levels of student spirituality.

Third, the identfisation of the dimensions of Christian education which are most closely related to higher levels of student spirituality could form a basis for further research into specific methodologies which promote spiritual nurture in those areas.

Fourth, the development of the spirituality Inventory (SI) coulc be utilized as a measure of perceived student spirituality in a variety of future studies. 


\section{Hypotheses}

Hypothesis 1

There is a significant difference in the levels of school spirituality between Seventh-day Adventist day academies in the United States.

Hypothes is 2

There is a significant difference in the levels of spiritual nurture between Seventh-day Adventist day academies in the United States.

Hypothesis 3

There is a significant relationship between the selected dimensions of Christian education and the perceived levels of student spirituality in seventh-day Adventist day academies in the Unfted States.

\section{Definitions of Terms}

Christian spirituality is the lived experience of Christian belief in the revelation of God through Christ and the holy Spirit. It focuses upon the response and impact that faith in the revelation of God has upon a person's consciousness.

Encountering Jesus refers to the experience an individual has when, through general and special revelation the Lord reveals Himself and $H$ is will in a way of which an individual is aware and conscious of His spiritual presence. 
Implied level of spirituality suggests that while it is not possible to measure actual spirituality, it is possible to imply a level of spirituality by the acknowledged presence of the inner and outer spiritual disciplines identified by the spiritual masters of the Christian church.

Spiritual awareness/consciousness is the ability to be conscious of the spiritual dimensions of human existence. It is humanity's ability to transcend one's own physical being for the task of seif-analysis as well as for the purpose of encountering the supernatural.

spiritual masters are leaders widely recoysiced by the Christian church throughout its history for their piety and commitment to God.

Spiritual nurture is the process of guiding, exhorting, and encouraging persons by word and action to grow in faith and love toward God and neighbor.

\section{Delimitations}

The following delimitations were adopted to achieve the objectives of the study:

1. The study was restricted to academy seniors.

2. The study was restricted to a sample of 20 Seventh-day Adventist day academies in the United States with school enrollments of not less than 50 . 


\section{Assumptions}

1. It was assumed that the SI dimensions selected for the study represent fundamentai areas of Christian spirituality.

2. It was assumed that the SNI dimensions selected for the study represent fundamental areas of Christian education by which student spirituality may be nurtured.

3. It was assumed that Christian education includes both conversion and spiritual nurture.

\section{Organization of the Study}

Chapter 1 provides an introduction and background to the study, a statement of the problem, the purposes and importance of the study, the operational hypotheses, and definition of terms. Also included are the delimitations, assumptions, and an organizational outine of the study.

Chapter 2 presents a review and discussion of literature related to Christian spirituality and spiritual nurture in Christian education in order to provide a theoretical background for the study and a credible basis for developing the spiritual Inventory (SI) and the Spiritual Nurture Inventory (SNI).

Chapter 3 presents a description of the methodology employed in the study. It describes the population and sample, instrumentation, instrument development procedures, data collection procedures, and the statistical analyses adopted. 
Chapter 4 presents an analysis and evaluation of the results of the study in terms of the stated hypotheses and the educational administrative implications. Chapter 5 presents a summary of the study. conclusions, implications for Christian educators, and recommendations for enhancing student spirituality in Christian schools. Areas for future research are suggested at the close of the chapter. 
CHAPTER II

REVIEW OF IITERATURE

\begin{abstract}
Introduction
This chapter presents a review and discussion of

literature related to Christian spirituality and spiritual

nurture in Christian education in order to provide a

theoretical background for the study and a credible basis

for developing the Spirituality Inventory (SI) and the

Spiritual Nurture Inventory (SNI). In view of the scope of

literature, the review seeks only to be representative

rather than exhaustive.

Accordingly, this chapter is divided into two

parts. Part one identifies from the writings of Christian spiritual masters those dimensions considered fundamental to Christian spirituality, and examines the principles and practices within those dimensions. Part two identifies from the writings of Christian education theorists dimensions of Christian education considered fundamental to nurturing student spirituality, and examinss the principles and practices within those dimensions.

According to the Christian literature reviewed in part one, a number of dimensions considered important to
\end{abstract}


Christian spirituality were identified. Foster (1978) convincingly articulated the general consensus among Christian writers in Celebration of Discipline: The Path to Spleitual Growth. He proposed a construct which consisted of 12 dimensions of spirituality.

While this study adopted the basic dimensional framework of Foster (1978) as a starting point, it redefined some of the dimensions and omitted the dimensions of fasting and simplicity. Fasting was omitted because of tise virtual rejection of the practice among Adventist young people, while simplicity was omitted because of the wide variation of understanding in different parts of the country. The 10 remaining aimensions adopted in this study and which constituted the framework for section one of this chapter included: meditation, prayer, study, confession, submission, solitude, service, worship, guidance, and joyfulness.

According to the Christian education literature reviewed in section two, a number of dimensions considered important for nurturing student spirituality were identified. Reflecting the collective thought of Christian education theorists and practitioners, the dimensions adopted for this study and which constituted a framework for section two of this chapter included: principal spirituality, school curriculum, teaching methodologies, school discipline, teacher spirituality, worships, 
community outreach, Bible teacher spirltuality, weeks of spiritual emphasis, and Bible classes.

\section{Dimensions of Christian Spirituality}

\section{Christian Soirituality}

The term "spirituality" does not have a meaning

common to all Christians. It appears that there is

divergency of thought because spirituality has a number of

dimensions and a broadness of meaning which is difficult to capture. Consequently, while the term is useful, it has the problem of not being easily defined in a universally acceptable way.

For the purpose of this study, the working definition proposed by McGinn and Meyendorff (1985, pp. xvxvi) was selected as a starting point.

Christian spirituality is the lived experience of Christian belief in both its general and more specialized forms. . . . It is possible to distinguish spirituality from doctrine in that it concentrates not on faith itself, but on the reaction that faith arouses in religious consclousness and practlce. It can likewise be distinguished from Christian ethics in that it treats not all human actions in their relation to God, but those acts which the relation to God is immediate and explicit.

$$
\text { According to this definition, Christian }
$$

spirttuality is a lived experience which is molded by Christian belief. It is a response to the divine initiative of God in Christ, the object of faith, and involves human actions which draw one into a personal relationship with God. Consequently, spiritual people are 
those who recognize the all-pervading presence of God, who seek to have a personal relationship with Jesus, who commit themselves to Christian discipleship according to scripture, and whose lives demonstrate the leading of the Holy Spirit.

The effect of entering Into this spiritual

dimension, according to Holmes $(1980$, p. 2), is that one grows into a closer relationship with God through the power of the spirit. He added, "We are 'unfinished' humans until we consent to that power of the spirit and are drawn into a wholeness of being." According to Underh111 (1937, pp. 5657).

It is through communion between the finite and the Infinite, the seeker and the sought, the creature man and creator sod . . . that the spirltual life develops in depth and power.

So the question which must be addressed was well expressed by Holmes (1980, p. 3), "How has Christian huran:t; throughout its history understood what it is to seek God and to know Him?" Humankind lives in the context of time and $i^{\prime} a$ world in which the one constant is change. Consequently, God has revealed Himself in varying ways throughout history in order to be understood by humans.

Although one's description of his/her personal encounter varies, there is striking similarity in the principles of how God "reaches out" to humans and enables response to the divine initiative. According to underhill (1937, p. 39-40), "our spiritual life is His affalr" 
because, whatever one may think to the contrary, "it is really produced by His steady attraction, and our humble and self-forgetful response to $1 t . "$

But while spiritual life "is His affair," a gift, which results from His inltiative, it nevertheless demands a human response. Tournier (1976, p. 144) argued:

After having created the whole inorganic world . . a world blindly and impersonally subject to Kim - God created man in His own image: that is to say, a personal being, a partner in dialogue, a being to whom he might spaak and sho could answer, to whom he gave liberty, and whose liberty, refusals and s1lences He respects, but whose replies he also awaits.

According to Foster (1978, p. 7), the response called for

is one of placing self before God so that one can be a recipient of His grace and transformed by His Spirit. He argued that such a response is facilitated through a life of spiritual discipline. Commenting further, Eoster (1978. pp. 7-8) stated:

God has given us the disciplines of the spiritual life as a means of receiving His grace. The disciplines allow us to place ourselves before God so that He can transtorm us. . . The disciplines. . put us where He can work within us. . . The path does not produce the change: it only puts us in the place where the change can occur.

\section{Meditation}

The dimension of meditation refers to the practice of taking time to center the mind on Christ and allowing Him to speak through the media of Scripture, the natural world, or the circumstances of life. 
The importance of meditation to spirituality was underscored in scripture. Isaac chose to spend much time in meditating on the blessings of God (Gen 24:63). Following the death of Moses, the Lord instructed Joshua: "Do not let this book of the law depart from your mouth: meditate on it day and night. . . " (Josh 1:8). The first Psalm calls all people to emulate the "blessed man" by meditating day and night on the law of the Lord (Ps 1:2). At the end of Ps 19, David prayed: "May the words of my mouth and the meditation of my heart be pleasing in your sight, O Lord, my Rock and my Salvation" (vs. 14). In the New Testament, Paul instructed Timothy to meditate on his instructions and to give himself wholly to them $(1 \mathrm{Tim}$ $4: 15)$.

Similarly, many of the spiritual masters in their writings have attempted to awaken Christians to the importance of meditation. Its importance for spiritual growth is illustrated by their insistence on making special time available for it each day. Kempis (1949, p. 233) counselled the believer. "Seek a suitable time for thy meditation, and think frequently of the mercies of God." Bonhoeffer (1954, pp. 81, 87) suggested that one should train $\mathrm{him} / \mathrm{herself}$ to set apart a regular hour for meditation. He even stated that "we have a right to this time, even prior to the claims of other people." In this same regard, White (1948, 1:433-434) advised the believer, 
You will recelve more strength by spending one hour each day in meditation. . . than you would spending many hours and days in studying the most able authors.

The purpose of spending this time in meditation and contemplative prayer, according to Merton (1969, p. 32 ), was not so much to find God as it was "a way of resting in Him" whom one had already found. Resting in him deepens the consciousness of one's relationship to Him as Lord (p. 104), and it helps one to be receptive to the presence of the "hidden action" of His Spirit (p. 48). Kempis" (1949, p. 249) emphasis was to focus on Christ with special attention being given to His passion. He counselled the believer :

Let thy contemplation be on the most High, and let thy supplication be directed unto Christ without ceasing. If thou canst not behold high and heavenly things, rest thou in the passion of christ and dwell willingly in His sacred wounds. . . and thou shalt find great comfort. . .

While the focus of meditation for the spiritual masters was Christ, the literature suggested a number of mediums which facilitated such a focus. Lawrence (1982, p. 60) advised that one medium he chose was through a heart of praise. He counselled that, irrespective of what one was doing, one should regularly stop for a few minutes in order "to praise God from the bottom of our hearts, to enjoy Him there in secret." Bonhoeffer (1954, pp. 81), on the other hand, emphasized that the period of meditation should be "devoted to the scriptures, private prayer, and intercession." As if to stress his point he added, "It has 
no other purpose. . . ." Despite the differing emphasis. Law (1728, reprinted in Stanwood, 1978, p. 169) suggested that:

All practices that heighten and improve our true appreciation of God, all ways of life that tend to nourish, raise and $f i x$ our affections upon Him are to be reckoned as so many helps and means to fill us with devotion.

It was apparent that in spite of the benefits of meditation, there are times, according to Bonhoeffer (1954, p. 82). "when we feel great spiritual drynese and epathy, and aversion, even an inability to meditate." He counselled that the one who seeks to enter into the inner regions of spirituality should "not be balked by such experiences" but should adhere to meditation "with great patience and fidelity" because "before long God's Word will come through." Similarly, Fox (1952, pp. 12-13) urged all "to wait patiently upon the Lord" irrespective of personal circumstances, because "there is a promise to you, and the Lord will fulfill it in you."

In summary, meditation refers to the practice of taking regular time to center the mind on Christ. It was an important feature in Scripture and in the experience of the spiritual masters. Meditating through the mediums of praise, Scriptural contemplation, meditative prayer, and silence enabled the masters to be more receptive to the Spirit of God. Through meditation the masters found changes in their lives and an increasing desire to move more intimately into the presence of God. 


\section{Prayer}

The dimension of prayer refers to the practice of maintaining communion with the one who is always present. It draws a person into the mind of Jesus which brings a deep sense of need and an ongoing desire to be more like Him.

The meaning of prayer was variously explained by the masters. According to the The Kneeling Christian, (An Unknown Christian, 1971, p. 54), prayer was simply "the turning of the soul to God," an acknowledgment of one's finitude and need of God. For Watts (1987, p. 67) prayer was "a holy conversation maintained between earth and heaven," between a holy God and sinful people, while for Underhill (1937, p. 61), prayer was really "our whole life toward God, our longing for Him." On the other hand. Buechner (1973, p. 23) suggested that prayer was talking to one's self about your one's life situation and believing "Sometusy̆ \pm is istening." According to Luther (Hillerbrand, 1974 , Luther's Works, vol. 52, p. 139), prayer was also to be understood not only as oral prayer but "everything a person does in God's word - - hearing, speaking, composing, and meditating. . . ."

It seems that all who have had a close walk with God have viewed prayer as the main business of their lives. The Psalms of both Moses (Ps 90) and David (Ps 17, 86, 142) suggested that prayer was an important part of their experience. Its importance for Jesus was illustrated by 
His practice of rising early in the morning for prayer and meditation (Mark 1:35). It was important also in the case for the apostles (Acts $6: 4$ ).

The spiritual masters considered prayer to be the foundation for Christian spirituality. Bounds 11979 . p. 50) suggested that "no ministry can succeed without much praying, and this praying must be fundamental, ever abiding, ever increasing." According to An Unknown Christian (1971, p. 63), "our spirituality and our fruitfulness are always in proportion to the reality of our prayers." Lawrence (1982, p. 79) maintained:

The most holy and necessary practice in our spiritual life is the presence of God. That means finding constant pleasure in His divine company, speaking humbly and lovingly with Him in all seasons, at every moment, without limiting the conversation in any way. (p. 59)

In discussing the purposes of prayer, Lewis (1958) suggested the opportunity it afforded for praising God. Bounds (1979, p. 122 ) belleved that spending more time in prayer would be a means of invigorating "many a decayed spiritual life," while Whitefield (1987, p. 304) suggested that prayer provided power to live in greater accord with the will of God. Tournier (1976, p. 113), on the other hand, suggested that while prayer would not deliver one from their natural tendencies, "it will bring us to recognize them for what they are, and thus continually to fresh experiences of grace." 
According to the literature, various approaches to prayer were employed by the spiritual masters. Some emphasized private prayer whlle others emphasized a prayer life that was fully integrated into daily living. Law (1987, p. 161) advocated the more formal approach to prayer, including the act of kneeling, closed eyes, bowing in silence, reverently addressing God, and adapting prayers according to one's personal circumstances and state of heart. Bounds (1979, p. 63) emphasized the need to meet with God in prayer early each morning. He argued that "the men who have done the most for God in this world have been early on their knees." He suggested that "if God is not first in our thoughts and efforts in the morning. He will be the last place the remainder of the day." on the other hand, while Luther (vol. 43, pp. 193, 194) recognized the need for the more formal approach to prayer, he believed it was a mistake to think of prayer time as being different from any other. People's actions, he said, should unite people with God when they are involved in their daily activities. Like Luther, many of the masters were continuously in prayer because they viewed prayer and life as an integrated whole and believed that if prayer was practiced in this way, it would result in joy and an increased capacity to love. Yet in spite of this differing emphasis, it seems that both approaches are important to spirituality in that private prayer appears to be a necessary prerequisite to a fully integrated prayer life. 
In summary, prayer refers to the practice of maintaining constant communion with the One who is always present. It seems that all who have had a close walk with God have viewed prayer as the main business of theif lives. While the purpose of prayer varled between masters, there was a common recognition that it was the foundation to all spiritual vitality and iffe. It was an opportunity for pralsing God, Invigorating spiritual life, providing power in svercoming temptation, and bringing fulfillment to one's experience.

\section{Study}

The dimension of study refers to the practice of applying the mind to understanding truth and ultimate reality. With scripture accepted as normative, it involves concentrated thought and evaluation of all things from a Christian perspective.

According to scripture, the need to discover objective truth is an important aspect of Christian spirituality. Jesus emphasized the importance of the knowledge of Himself when He counselled: ". . know the truth and the truth w11l make you free" (John 8:32). Paul also suggested that transformation and spiritual growth were in part a function of study. He urged the believer to center on those things which were true, honorable, fust. pure, lovely, and gracious ( $\mathrm{Phil} 4: 8$ ) because it enabled 
one to test and understand "His good, pleasing, and perfect will" (Rom $12: 2$ ).

Although reasons varied, understanding truth was also important to the spiritual masters. According to Taylor (1957, p. 193), "reading and hearing the word of God are. . Instrumental to falth" and "to all other graces of the spirit." Watts (1987, p. 81) urged the need to "maintain a constant exercise of reason and judgment. . . anidst all the workings of devout exercises." He added that the scriptures were given to guide people in their inquiries into "the things of . . . everlasting welfare." For Kempis (1949, p. 213), studying the sources of divine revelation was a means of wisdom. He suggested that the focus of study should be the nature of lod reveaied in Christ. Merton (1969, p. 98) believed that "the spiritual life needs strong intellectual foundations." The Bible speaks of a twofold revelation of God: the revelation in nature (Ps $19: 1-2$, Rom $1: 19-20$ ) and the revelation of Scripture ( $1 \mathrm{Kgs} 17: 13,2 \mathrm{TIm} 3: 16-17$, Heb 1:1-2). According to the literature, the spiritual masters frequently utilized the natural sources of revelation in theif quest to know God. For example, Lawrence (1982, p. 86) spent much time seeking God in nature. "He observed in each of creation's wonders God's wisdom, His goodness, and the different characteristics of His power." speaking of the value of the natural world, Dostoevski (1952, p. 167) counselled: 
Love all God's creation, the whole and every grain of sand in it. Love every leaf, every ray of God's light. Love the animals, love the plants, love everything. If you love evervthing: you will perceive the divine mystery in things. Once you percelve 1t, you will begin to comprehend it better every day.

Lewis (1952) argued that the study of human nature might

also be an important means of spiritual growth. For

example, he suggested that people's natures provide

evidence of a Creator God, yet they also point to the need

for a Savior.

On the other hand, it is clear that scripture is

the foremost medium for study. Speaking of its

significance in relation to spirituality, Harkness (1953.

p. 52) commented that "there is no greater book than the

Bible." It is also clear from one of the prayers of Kempis

(1949, p. 269), that the study of Scripture was very

important to him in his quest for truth. iie piejyed:

I beseech Thee humbly and earnestly. Speak for

Thy Servant heareth. Let not Moses speak to me, nor any prophet, but rather speak thou, O Lord, who didst inspire and illuminate all the prophets; for Thou alone without them canst perfectly fill me with knowledge, whilst they without Thee shall profit nothing.

In summary, study refers to the practice of applying the mind to understanding truth and ultimate reality. The pursult of truth through study was admonished in Scripture and exemplified in the lives of the spiritual masters. The masters believed study to be important for the sake of wisdom and spiritual growth. The Bible speaks of a threefold revelation of God: a revelation in nature. 
in human consciousness, and the Word of God. According to the literature, the spiritual masters frequently utilized

the natural sources of divine revelation, although, it was clear that the study of scripture was regarded as the primary medium for spiritual growth.

\section{Confession}

The dimension of confession refers to the practice of recognizing one's sinfulness and the need to be reconciled to God through Christ by the confession of sin. It also involves a preparedness to forgive others and to seek forgiveness from those whom one has wronged.

The confession of sin is a predominant theme of Scripture because it lies at the core of life in Christ. Scriptural writers have stressed its importance and one commented: "He that covereth his sins shall not prosper: but whoso confesseth and forsaketh them shall have mercy" (Jrov 28:13; Cf. 1 John $1: 9$, Jas $5: 16$ ). similarly, the spifitual masters belleved confession to be an important feature of spirituality. For example, st. Prancis (The Admonttions XXIV, 1964, p. 85) commented:

A man is a faithful and prudent servant (Matt 24:45) when he is quick to atone for all his offenses, interiorly by contrition, exteriorly by confessing them and making reparation.

Being overwhelmed with the love of God, Rowe (1737, reprinted in Jeffrey, 1987, pp. 103-104) exclaimed: 
Why have I provoked the God on whom my very being every moment depends? . . With what words shall I choose to address thee? "Pardon my iniquity, O Lord: for it is great."

- . Wondrous love, astonlshing generosity! Let me never live to repeat my ingratitude. . . .

The importance of confession was also underscored by Harkness (1953, p. 39). He stated: "Without repentance there can be no forgiveness, and without forgiveness no newress of life."

A number of reasons were offered for its importance to spirituality. Harkness (1953, p. 39) suggested that through confession the heart was made ready to receive God. He argued that one could not find God until one faced his/her shortcomings and in humility seeks His Forgiveness. Tournier (1962, pp. 198, 213) underscored the healing nature of confession by suggesting that repentance is the divine solution to the problem of human guilt. Schaeffer (1972, p. 126) described this process as "freedom from the bondage of conscience," while Newton 11787 , reprinted in Jeffrey, 1987, pp. 428-429) spoke of it as peace of $m$ ind. For Bonhoeffer (1954, pp. 112-114), on the other hand, "confession is conversion." a conversion to a new way of ilfe. He argued that

In confession the light of the Gospel breaks into the heart and mind of the Christian believer, and the life of God portrayed through the cross. roots out the sin of pride. . . . In confession the break-through to new life vccurs.

While it was apparent that the masters believed forgiveness occurred by faith in the righteousness of 
Christ, a number of guidelines important to the discipline of confession were offered, st. Alphonsus Luguori (1964. z. 192) suggested that three things were necessary in true confession of sin: an examination of conscience, sorrow, and a determination to avold sin. White (1956, p. 38) added that all confession should be specific, acknowledging the very sin of which one was guilty. On the other hand, Luther (vol. 42, p. 66), suggested that the forgiveness of God was conditional on the believer's preparadness to forgive others. Falling to forglve another, according to Luther, was like saying, "O God, as I am Your debtor, so I also have a debtor; since I will not forgive him, do not forgive me." Schaeffer (1972, p. 85) also added the guideline that to live a life of freedom from deliberate sin necessitated "a moment by moment, increasing. experiential relationship to Christ and to the whole Trinity."

In summary, confession refers to the act of recognizing one's sinfulness and the need to be reconciled with God through Christ. Scripture and the spiritual masters readily acknowledge the importance of confession because it lies at the core of life in Christ. The literature also suggested that it prepares the heart to recelve God; restores peace of mind; and provides power to walk in newness of life. A number of guidelines $=5 f e r e d$ for 1 ts practice included: listening to conscience, being sorry for sin, openly acknowledging specific sin, having a 
determination to avoid sin, having a preparedness to forgive as God forgives, and living in close communion with Christ.

\section{Sol1tude}

The dimension of solitude refers to an attitude of mind which contlaually seeks to be in tune with God. While outward solitude refers to times of physical isolation sought for meditation and prayer, inward solitude refers to an atiltude of mind which is attuned to God irrespective of time, piace, or circumstance.

In reviewing the devotional ifterature, the terms

"inward solitude" and "inward silence" were often used interchangeably by the masters. For example, the book the Imitation of Christ (Kempis, 1949) had a section entitled "On the Love of Solitude and Silence:" while Merton (19so) and Bonhoeffer (1954) used the terms synonymously. In fact, Bonhoeffer (1954, p. 79) stated: "The mark of solitude is silence. . . Silence is the simple stiliness of the individual under the Word of God."

It is apparent from Scripture that the life of Jesus was one of continuous "heart solitude." Whether He was alone or in the midst of the crowd, His mind was continually attuned to His Father's voice. However, it seemed evident that christ frequently sought outward solace for the purpose of cultivating inward solitude. He not only sought a solitary place for prayer each morning (Mark 
$1: 35)$ but also sought outward sclitude prior to commencing his ulnistry (Matt 4:1-11), before selecting the 12 disciples (Luke $6: 12$ ), on receiving news of John the Baptist's death (Matt 14:13), and prior to the ordeal of the cross (Matt $26: 36-46$ ). It would seem from the example of Christ that inner peace, irrespective of personal circumstances, was a function of the qujet times spent in communion with God.

The literature also underscored the importance of solftude for Christian spirituality. For example, Nouwen (1975, p. 23) proposed that

The movement from loneliness to solitude is the beginning of any splrltual life because it is the movement from the restless senses to the restful spirit. . . . Do not run, but be quiet and silent. Listen attentively to your own struggle. The answer to your question is hidden in your own heart.

Also speaking of the value of silence to spirituality. Isaac of Niniveh (cited in Merton, 1969, p. 33) stated:

If you love truth, be a lover of silence. silence like the sunlight will illuminate you in God . . Silence will unfte you to God himself. .

It appears the importance of solitude is the occasion it provides for God to commune with the believer.

Although important to spirituality, there appears to be variations in how it should be practiced. On one hand, Kempis (1949, p. 234-235) suggested: "Enter into thy chamber and shut out the tumults of the world. . thou shalt not elsewhere find so great peace." By contrast, 
Lawrence (1982, p. 8) emphasized the necessity to continually "practice the presence of God" in all of life's activities. He counselled:

Always be aware of God's presence by talking with HIm throughout each day. To think that you must abandon conversation with $\mathrm{Him}$ in order to deal with the world is erroneous.

According to Nouwen (1975, pp. 25, 26, 28), listening and conversing with the world around one's self becomes a part of the Christian's meditative silence. He argued:

The solitude that really counts is the solitude of heart; it is an inner quality of attitude that does not depend on physical isolation. . . When we live with a solitude of heart, we can listen with attention to the words and the worlds of others.

It would seem that the emphasis given by Kempis (1949) to "outward solitude" was not one that Lawrence (1982) or Nouwen (1975) would disagree with, rather, they would argue that it was designed to enhance the devotional life needed for true "inward solitude." Whatever the emphasis, it seems clear that both are important to the practice of solitude and to the spiritual life.

In summary, Christian solitude reiers to inner peace of mind that is continualiy tuned to the voice of God. The literature suggested that seeking "outward solitude" (place solitude) for personal devotions is necessary to enhance the practice of "inward solitude" (heart solitude) during the busy times of life. The close connection between solitude and silence suggests that the main feature of solitude is the act of listening when one 
encounters the voice of God and experiences the peace that passes understanding.

\section{Submission}

The dimension of submission refers to the general principle of placing the interests of God and others ahead of self. It is primarily concerned with how a relationship of obedience to God impacts the relationship between the believer and others.

The biblical teaching on submission centers around the call of Christ: "If any man will come after me, let him deny himself, and take up his cross, and follow me" (Matt 16:24). While obedience to Christ is implicit in this passage, it is fundamentally concerned with how a believer's relationship with Him impacts relationships with others. The essence of submission in scripture is best captured by Christ:

Whoever wants to become great among you must be your servant, and whoever wants to be first must be slave to all. For even the Son of Man did not come to be served but to serve. . . (Mark 10:43-45)

Accordingly, scripture does not attempt to establish a hierarchy of appropriate relationships, but rather seeks to communicate an attitude of mutual subordination. Peter instructed his brethren to be subject to each other because the grace of God was given only to those who humbled themselves before others ( 1 Ret 5:5). Paul called the Philippians to unity and humility by stating ". . In lowliness of mind let each esteem the 
other better than ourselves" (Phil 2:3). He similarly instructed the Ephesians: "Submit yourselves one to another in the fear of God" (Eph 5:21).

The literature also suggested that the practice of submission was an important feature of Christian spirituality. For example, Kelly (1957, p. 48) commented that Christian commitment entalled "complete obedience, without any reservations," and he called believers to commit their lives in "unreserved obedience to Him." According to the Letters of Newton 11787 , reprinted in Jeffrey, 1987, p. 444), the Christian life necessitated "that much within us and much without must be resisted." He argued that

We must learn to cease from depending upon our own supposed wisdom, power, goodness, and from selfcomplacency and self-seeking, that we may rely upon Him whose wisdom and power are infinite.

White (1956, pp. 79-80) also underscored its importance by suggesting that submission strengthened a person's spiritual nature.

Two prerequisites for Christian submission seem to stand out in the literature. Bonhoeffer (1954, p. 109) spoke of "the faithfulness with which a man serves Jesus Christ." This suggests that genuine submission and selfsacrifice for others is dependent upon the degree to which Christ's life of submission is the focus of one's life. Merton (1969, p. 92) spoke of the need for "serious and humicle prayer, united with mature love. . . " He argued 
that through a sincere prayer life one would manifest a "spirit of sacrifice and concern for others that is unfallingly generous. . . ."

It appears that Christian sibmission manifests itself in a varlety ways. With respect to God, Law (1728, reprinted in stanwood, 1978, p. 47), stated:

He is devout who lives no longer according to his own will or the way and spirit of the world, but to the sole will of God; he considers God in everything, serves God in everything, makes all the parts of his common life aspects of his worship by doing everything in the name of God and according to such principles as are conformable to his glory.

With respect to other people, Bonhoeffer (1954) suggested: "Look upon yourself as inferior to all" (p. 97): "To serve our brother, to please him, allow him his due.. . is the way of self-denial, the way of the cross" (p. 118). For Calvin (1952, p. 29), Chrịtian submission implied seeking the good of everyone without exception, even though the majority were very undeserving when judged according to their own lives. He argued:

We must not think of man's real value, but only of his creation in the image of God to which we owe all possible honor and love.

Yet this general principle of placing the interests of others ahead of self did not deny the importance of self-interest for example in caring for one's physical, emotiunai, and spiritual development and self esteem in order to allow a sense of the possibility of being used in God's service. 
In summary, submission refers to the general principle of placing the interests of God and others ahead of self. The biblical teaching of submission centers around obedience to God and self-sacrificial love to all people. The masters, in recognizing the importance of submission to Christian spirituality, identified two primary prerequisites: the centrality of christ in the life and an earnest prayer life. The literature suggested that submission to God entailed: consldering Him in everything. serving Him in everything, and doing everything in His name and for His glory; while submission to others entailed: kindness, trust, respect, humility, and fairness.

\section{Service}

The dimension of service refers to the practice of serving others with humility as a personal response to the grace of God. It is a consciously chosen course of action and is for the most part a secret work.

The importance of Christian service as a dimension of spirituality is underscored throughout scripture, especially in the ministry of Christ. Notwithstanding the need to emulate Christ's example (Matt 20:25-28), Paul suggested that Christian service should be a loving response to the grace of God. He believed that in view of God's mercy, people should offer themselves in service to Him (Rom 12:1). Elaborating further, Paul argued the need to serve others with sincerity, to honor and respect all 
people, to practice hospitality, to show goodwill to enemies, to empathize with those who hurt, and to serve humbly those society despises (Rom 12:12-18).

The importance of Christian service as a dimension of spirituality was underscored throughout the literature, although perspectives of purpose varied between spiritual masters. Merton (1964, p. 89) commented that Christians were called to serve for the purpose of meeting human needs. He stated that "Christian charity is meaningless without concrete and exterior acts of love." Emphasizing another perspective, Schaeffer (1972, p. 87) argued that Christians were called to serve to demonstrate the existence of a loving God. According to St. Francis (II Cel. 175, reprinted in Hermann, 1964, pp. 44-45), Christian service provided opportunity for sharing the Gospel. He argued that through the demonstration of love recipients might be lead to an acceptance of Christ. White (1956, p. 80$)$ suggested that Christian service nurtured spirituality in the one who serves. She argued that the only way a christian grew in grace and hurility was by engaging in service. In spite of the differing emphases, it seems that each purpose represents another aspect of the call to discipleship.

It seemed from the literature that Christian service entalled a recognition that service was work performed on behalf of God and for the purpose of meeting the needs of others. With respect to the first, Kelly 
(1957, p. 102) suggested that social concern was a Godinitiated work for the world. Yet he argued that such a work was "made special and emphatic and unique. particularized in each individual or group" who was sensitive to the love of God. With respect to the second, Bonhoeffer (1963, p. 8), prior to his imprisonment by the Gestapo, wrote: "When Christ calls a man, he bids him come and die." It seems that his view of Christian service was one of unreserved giving to others in response to Christ. It was apparent $i \bar{A}$ The Cost of Discipleship that Christian service was not something to be paraded, rather its virtue is only realized when it was performed as a non-public work (p. 143). He stated, "The genuine work of love is always a hidden work." Taylor (1957, p. 353) captured the nature of this work when he commented:

Love to be concealed and little esteemed: be content to want [lack] praise, never be troubled when thou art slighted and undervalued. . . ."

Dietrich Bonhoeffer's Life Together (1954) and Henry Nouwen's Reaching Out (1975) identified ways Christian service might be manifested. Eirst, both autinors spoke of the importance of "listening" to the "stories" of people (Bonhoeffer, 1954, p. 97; Nouwen, 1975, p. 75). They suggested that the greatest need of many was the need to be heard by one who showed empathy. Bonhoeffer (1954) spoke of "active helpfulness" as an important service for the Christian community. "Active helpfulness" necessitated allowing one's self to be interrupted by God. He stated: 
God will be constantly crossing our paths and canceling our plans by sending us people with claims and petitions. (p. 99)

Commenting in this same regard, Nouwen (1975, pp. 36, 37)

quoted a former professor:

You know, . . . my whole life I have been complaining that my work was constantly

interrupted, until I discovered that my

interruptions were my work. . . Our interruptions

are in fact our opportunities. . . .

Second, Christian service might be manifested

through practicing personal and corporate intercessory

prayer. Bonhoeffer (1954) argued that the only way a

person might reach another was through the Holy Spirit. He

believed that intercessory prayer was "the purest form of fellowship" (p. 88).

Third, Nouwen (1975) maintained that Christian

service might be mantfested by the practice of converting one's hostidities into hospitality (p. 46), "a reaching out toward our neighbor whereby we perceive life as a gift not to possess but to share" (p. 78). He maintained that reaching out in hospitality toward another entalled: helping, serving, caring, guiding, and healing. It meant a life of giving and sharing.

In summary, service refers to the practice of serving others with humility as a personal response to the grace of God. The importance of Christian service as a dimension of spirituality was underscored in scripture and the literature, although perspectives of purpose varied 
42

between spiritual masters. It appeared also that the nature of Christian service entailed recognizing it first as the work of God in the world and second as giving one's self for others. A number of ways christian service could be manifested included: "Iistening" to the "stories" of people: practicing personal and corporate intercessory prayer: and converting hostility into "hospitality."

\section{Worship Celebration}

The dimension of worship celebration refers to the practice of foining a community of believers as a response to God's love and entering into His presence with reverence, praise, and adoration.

Throughout the literature, the meaning of worship was defined either from the perspective of an individual's response to God or a corporate response. For example. Ferre (1951, p. 15) defined worship as an individual believer's whole life response to God. He suggested that "worship is the baring of one's whole life unto God" and he added that "worship is not only the occasional standing on holy ground but the constant living on 1 . " on the other hand, Kelly (1957, p. 71) defined worship in the broader context of corporate fellowship by suggesting that worship is the community of believers gathered together for the purpose of collectively expressing their love for God. In recognizing this twofold view of worship. Massey (1985, p. 103) convincingly argued that both perspectives was 
necessary for authentic worship identified in scripture. He argued that while worship might be viewed as a personal response to an encounter with God, an added dimension was given to the experience when believers celebrated together. He stated: "Authentic worship of God leads a person into community celebration" where "worship celebrates the God of a cominunity, the God who is Father of the human family." Scripture is replete with examples of God calling His people to worship Him. The first four commandments call people to worship God, to reverence His holy name, and to worship HIm as Creator and Lord (Exod 20:3-11). The Psalmist calls all to worship God whose majesty is observed throughout creation (Ps 66:4) to "worship the Lord in the splendor of His holiness" (Ps 96:9). Jesus stated: "The true worshipers will worship in truth and spirit" (John $4: 23)$.

The literature often alluded to the connection between worship celebration and spirituality. According to Steere (reprinted in Harkness, 1953, pp. 36-37), corporate worship was needed if bellevers were to grow in theis understanding of the nature of love. He argued that "inner growth" was in part a function of active particlpation in the religious 11 fe of the believing community. Saliers (1984, p. 37) argued that insofar as worship was an expression of thanks for the gift of love, it spoke to a deep human need. He suggested that a life devold of 
gratitude became incapable of receiving gifts and eventually of giving gifts.

It seems from the literature that authentic corporate worship is contingent on two features. First, authentic worship focuses on Christ. Bonhoeffer (1954, pp. 21, 39) suggested that with Christ as the central focus of worship, the Christian community became united. Second, authentic worship is dependent on the practice of prayer. According to Nouwen (1975, p. 112), the community of believers "Is created as well as expressed" through the medium of prayer. He suggested that prayer was "the language of the Christian community." He argued:

When prayer is no longer its primary concern, and when its many activities are no longer seen and experienced as part of prayer itself, the community quickly degenerates into a club with a common cause but no common vocation. . . Prayer is first of all the realization of God's presence in the midst of his people and, therefore, the realization of the community itself.

The literature also suggested a number of benefits that could be derived from Christian worship. Kelly (1957, p. 25) suggested that it leveled cultural, educational, national, and ractal differences. Steere (in Harkness, 1953, pp. 40-41) suggested that corporate fellowship fostered social consciousness, helping the believers to be mindful of their responsibility to care for others. Steere (in Harkness, 1953, p. 42) also believed that corporate fellowship nurtured private devotional life. In contrast to Lawrence (1982, p. 29), who believed that the believer 
must first sense the reality of God's presence in daily

life before being able to sense the reality of God's presence in corporate worship, steere (1953) argued that the believer gained faith and courage from corporate worship which fostered a desire for greater personal communion with God.

In summary, worship is both an individual and a corporate response to God's love and to His call to enter into fellowship. Scripture is replete with examples of God calling His people to worship while the literature often alludes to its importance in relation to spirituality growth. It seems that authentic corporate worship is contingent on two features: focusing on Christ and the practice of prayer. The literature also suggested a number of benefits of corporate worship: it leveled cultural, educational, national, and racial differences; it provided joy and fulfillment; it fostered sccial conscicusness; and it nurtured the devotional life.

\section{Guidance}

The dimension of guidance refers to the practice of seeking God's will in the decisions of life. It is the practice of being receptive to divine guidance through Scripture and/or other avenues through which God may communicate His will.

Scripture regards faith in providential guidance as fundamental in the divine-human relationship. The Psalmist 
recorded: "I will guide thee with mine eye" (Ps 32:8); "He will be our guide even unto death" (Ps 48:14); "Thou shalt gulde me with thy counsel" (Es :3:24). Concerning the restoration of Jerusalem, Isalah stated: "The Lord will guide you always" (Isa 58:11). Jesus described the nature of His Father's care for His people by using the image of a good shepherd. He stated:

He calls his own sheep by name and leads them out. When he has brought out all his own, he goes on ahead of them, and his sheep follow him because they know his voice. (John 10:3, 4)

From these and other biblical declarations the Bible speaks plainly about the need for the believer to trust in the promise of divine guidance in daily experience. The literature underscored its importance to spirituality by suggesting that a believer's faith and obedience were functions of a relationship with Christ. For example, Calvin (1952, p. 24) suggested that a true relationship with Christ manifested itself in surrender to the guidance of the Holy Spirit. For Newton (1787, reprinted in Jeffrey, 1987, p.435), faith in the divine will seemed to be a reality in his life. In one of his Letters, he stated:

Let me have his presence and his spirit, wisdom to know my calling, and opportunities and faithfulness to improve them; and as to the rest, Lord, help me to say: "What thou wilt, when thou wilt, and how thou wilt."

Its importance was underscored in a number of other ways. For example, according to Augustine (cited in 
Geisler, 1982, pp. 143-145), the Holy Spirit was the source of love and faith; lead to salvation: and justified, regenerated, and sealed the believer in Christ. For Newton (1787, reprinted in Jeffrey, 1987, p. 433), the Holy Spirit served to protect. He stated:

We cannot be safe, much less happy, except in proportion as we are weaned from our own wills and made simply desirous of being directed by his guidance.

According to Schaeffer (1972, pp. 69, 71), the Holy Spirit was "the agent of the power and the person of the glorified Christ." He also suggested that true spirituality was not achieved in one's own energy, but rather by means of the work of the HoIY Spirit in one's life.

The literature also spoke of a number of media by which the Holy Spirit guided the believer. According to Smith (1970, p. 67), the spirit guided through scripture, through the providential circumstances of life, through convictions of personal judgment, and through the inner impressions on people's minds. Yet to recognize and interpret the will of God, she argued the need to use principles of scripture as the normative guide. Stanley (1985, pp. 51-54) added that it was also important for there to be basic harmony between the various media. He argued that the directives of the Holy Spirit would always harmonize with themselves.

In summary, this dimension refers to the practice of seeking God's will in the decisions of life. In 
scripture and the literature, providential guidance was seen as an important element of Christian spirituality. A believer's faith and obedience to the Holy spirit were viewed as a function of a relationship with Christ. The literature identified a number of media by which the Holy Spirit guided the believer: scripture, circumstances of Iife, personal fudgment, and inward impressions; but suggested that interpreting the will of God required harmonizing the media and viewing scripture as normative.

\section{Joyfulness}

Joyfulness refers to a believer's spontaneous response to the gracious provision of God. It is characterized by love, happiness, and a spirit of thanksgiving for the gift of salvation in Jesus and the abundant blessings of life.

The joyful response of the believer is often alluded to in Scripture. The Psalmist frequently called believers to express their joyfulness in the Lord (Ps $66: 1$ : $81: 1 ; 95: 1 ; 100: 1)$. Isalah also underscored the promise of foy to those who remained true to the covenant of Yahweh (Isa 56:6-7). Although Paul often spoke of the crossbearing nature of Christianity, he also recognized the life of joyfulness found in the gospel. He counselled the Philippian believers:

Rejoice in the Lord always. I will say it again: Rejoice! . . . The Lord is near. Do not be anxious about anything, but in everything, by 
prayer and petition, with thanksgiving. . . (Phil $4: 4-7)$

According to the Westminster Cathechism. "The chief end and duty of man is to love God and to enjoy $\mathrm{Him}$ forever." For Schaeffer (1972, pp. 91, 95), the relationship with Christ should be a source of real joy. He stated: "We are not called to serve God just any way but to know joy and peace in believing." White (1956, p. 115) made the observation that the life of the believer should witness to the joyfulness of Christian living. She suggested that such a life should be a natural outgrowth of an authentic relationship with Christ. In one of his Sermons, Wesley (1765, reprinted in Jeffrey, 1987, p. 224) suggested that many sorrow because they were "aliens from the commonwealth of Israel." He argued that when the Comforter enters into the heart of the believer, his/her foy will be full. He stated that "we joy in God through Christ. . . by whom we have access into grace."

According to the literature, joyfulness was also a central feature in the lives of the spiritual masters. Kempis (1949, p. 246) overflowed with the desire always to praise God in response to "the spiritual refreshments of the soul" which God bestowed on him. He stated:

0! if no other duty lay upon us but to praise the Lord our God with our whole heart and voice! on! if thou never hadst need to eat or drink, or sleep, but wert always able to praise God, and to give thyself to spiritual exercises alone. . . . 
According to Celano (cited in Hermann, 1964, p. 43), the life of Francis was filled with joy. He observed that in the midst of his greatest suffering he remained filled with joy. He exclaimed in admiration:

0 martyr and martyr, who smiling and rejoicing most willingly put up with what was most bitter and most difficult to bear. (I Cel. 107)

The life experience of Lawrence (1982, p. 72) was very similar. Practicing the presence of Gcd filled him with a sense of joy. He remarked:

Experiencing the unceasing presence of God, gives me such contentment and joy, that I sometimes feel compelled to do rather childish things to control it. (p. 37 )

While the dimension of joyfulness might be seen as a response to the spiritual life in Christ, it appears that three major aspects undergird the life of joy. First, Nouwen (1975, p. 103) identified one aspect as "the prayer of the heart." He suggested that the prayer of the heart gave the believer "an immense joy and unspeakable experlence of God's presence." Second, Smith (1970, p. 147) identified another aspect as "the joy of obedience." In her book The Christian's Secret of a Happy Life, she argued that joy resulted from obedisnce to Christ. She maintained that without obedience to the will of God, joy was "hollow and artificial." A third aspect which undergirds the life of joy was the practice of loving service. In an interview, Mother Teresa lcited in Feistritzer, 1976, p. 30) suggested that it was with joy 
that one must sontact Christ under the mask of wratchedness and poverty because "Joy is love." She added: "Joy is a prayer; foy is strength; joy is a net of love in which you can catch souls." Simflarly, Tournier (1976, p. 51) suggested that love was the meaning of all human adventure. He argued that the instinct to love, to give oneself in service to others was a source of joy. In summary, foyfulness refers to a believer's response of love, happiness, and thanksgiving for the gracious provision of God. It is an important aspect of Christian spirituality because it should be a spontaneous response to a bellever's life in Christ. Joyfulness was an important feature in the Psalms and in the writings of Paul. The literature also provided examples of the masters whose lives were a continual testament of joy. While the dimension of joyfulness may be seen as a response to the spiritual life in Christ, it appears that prayer, obedience, and loving service, undergird the life of foy.

\section{Dimensions of Student Spiritual Nurture}

\section{Spiritual Nurture}

Spiritual nurture should foster a personal response and commitment to Christ and cultivate a relationship with Him which results in Christian growth. According to Flynn $(1985)$ and stone $(1985)$, it was a process which took place in partnership with the Holy Spirit and through prayer, Scripture, worship, and service. 
In Christian Nurture, Bushnell (1947, p. 4) argued "that the child is to grow up a Christian, and never know himself as being otherwise." Contrary to what was commonly assumed, Bushnell argued that a child should not be left to grow up "in sin" with a view to belng converted at a mature age, but rather, should be taught what was good from the earliest years. Commenting on the importance of spiritual nurture, he stated. "Teaching is to be that which feeds growth, not that which stirs revolution" (p. 328). While much of the literature today generally supported Bushnell's contention, some theorists have argued that Christian education entails the work of both conversion and nurture (Ozment, 1956, pp. 200-213).

This study took the position that Christian education included both conversion and spiritual nurture. While conversion is a focal point, the work of spiritual nurture following the initial commitment to Christ was the essential concern of this study.

The framework for the discussion of each dimension that follows includes: a definition; the importance of the dimension in nurturing spiritual growth; the nature, philosophy, and goals of the dimension: and the principles and practices within the dimension which are likely to nurture and enhance student spirituality. 


\section{Principal spirituality}

Principal spirituality refers to the depth of relationship the educational administrator has with Jesus Christ and the extent to which he/she assumes the role of spiritual leader in the school. Further, it is defined as the degree to which the principal exemplifies a life of devotion to God, leads faculty and students into an intimate fellowship with Christ, and adopts leadership strategies which enhance Christian growth.

The importance of the leadership role as a facilitator of spiritual growth permeated the literature. According to Sanders (1980, p. 19), "the overriding need of the church. . Is for a leadership that is authoritative, spiritual, and sacrificial." He argued that the church has always prospered when there were strong spiritual leaders who "expected and experienced the touch of the supernatural in their service." Similarly, Engstrom (1983, pp. 35-36) commented that "the Body of Christ" was strengthened immeasurably through the "spiritual gift" of Christian leadership. He suggested that the Christian leader had an important spiritual role within "the Body of Christ" which involved leading and guiding others into an intimate fellowship with Christ.

The nature and philosophy of this Christian leadership role was discussed as a function of the call of God, servanthood, followership, transformation, and a leader's prayer life and Holy Spirit empowerment. The 
54

flrst aspect considered whether Christian leadership was a function of birth, circumstance, or "the call of God." In addressing this question, Sanders (1980, pp. 30-32)

suggested that Christian leadership was not so much a function of birth (Great Man and Traitist Theory), or circumstantial fate (Situational Theory), or the cultivation and development of skills (Learning Theory), but rather a function of "the call of God." While Sanders did not deny the significance of these theories, he argued that spirttual leadership and authority were explained more in terms of "a gift of the spirit" given in response to personal commitment than on the basis of naturalistic factors. It would seem that when a person responded in personal commitment to the Lord, the Holy Spirit called and directed according to a person's spirltual gift for the benefit of building up "the Body of Christ."

The second aspect of leadership described in the ilterature was the servanthood nature of Christian leadership. In contrast with the concept of "upward mobility" (Presthus, 1962) found in general leadership literature, Christian leadership, according to Greenleaf (1977), was "a call to servanthood". He stated:

A new moral principle is emerging which holds that the only authority deserving one's allegiance is that which is freely and knowingly granted by the led to the leader in response to, and in proportion to, the clearly evident servant stature of the leader. (p. 10) 
Engstrom (1983, D. 5a) added tiat "to lead is to serve, and to serve is to become the servant of those one is leading." He later implied that to be a servant was to pattern one's iffe after Christ.

A third aspect was the followership nature of Christian leadership. While Lipham (in Cunningham \& Gephart, 1973, p. 6) suggested that leadership was a function of forcible domination and coercion, Getzels (in Cunningham \& Gephart, 1973, p. 16) argued that "leadership depends on followership," and that it was a function of "cooperation and mutuality" between leader and follower. Similarly, Burns (1978, p. 19) defined leadership as Leaders inducing followers to act for certain goals that represent the values and the motivation, the wants and needs, the aspirations and expectations of both leaders and followers. . . . Leadership, unlike naked power-wielding, is thus inseparable from followers' needs and goals.

A fourth aspect was the transformative nature of leadership. Burns (1978, p. 20) identified this aspect as "transforming leadership." He maintained that such leadership occurred when, through interaction, leaders and followers raised one another to higher levels of motivation and morality. He identified various names which were often used to describe such leadership: elevating, mobilizing, inspiring, exalting, uplifting, preaching, exhorting, evangelizing. Bennis \& Nanus (1985, p. 17) added that such leadership "instills within employees commitment to change." It appears that this view might have important 
implications for Christian educational leaders (principals) when considering the ways in which leadership could impact the spiritual lives of young people.

A final aspect, according to the literature, was that the power of Christian leadership in nurturing splritual growth was a function of a leader's prayer life and Holy Spirit empowerment. According to Lall \& Lall (1979, p. 50), a leader needed to be "a man of srayer," "a man who is in-touch with God." Sanders (1980, p. 112) suggested that spiritual leadership could be exercised only by spirit-filled men. In fact, he commented that while other qualifications were important, "to be spirit-filled is indispensable" to effective spiritual leadership. He asserted :

The spiritual leader influences others not by the power of his own personality alone but by that personality irradiated, interpenetrated, and empowered by the Holy Spirit. Because he permits the Holy spirit undisputed control of his iffe, the spirit's power can flow unhindered through him to others. (p. 33)

It would seem, then, that the ability of Christian leaders to impact the spiritual lives of young people is in direct proportion to their practice of tapping into the eternal source of power in the person of the Holy spirit.

The literature suggested that a school principal was able to nurture student spirituality in a variety of ways. First, Grissen (1981/82, p. 4) observed that a principal's interaction with and concern for the spiritual growth of faculty had a direct bearing on the level of 
57

school spirituality. In an editorial on the impact of Christian education, she commented on the Christlike envifonment of a school she visited. She noted: "There was a caring concern, a kindly compassion that permeated the atmosphere." She suggested a reason for this distinctiveness was due primarily to the nurturing leadership style of the principal.

Second, Jaqua (1972) suggested that the life and actions of the principal which "exemplify the spirit of devotion to God" was a key to spiritual direction in a Christian school. He stated:

The Christian school must have leaders who are dedicated to God and have a personal Christian experience that expresses the fruit of the spirit.

Jaqua (1972) argued that it was one thing for the leader to have the appropriate Christian certification but quite another for the leader to qualify in the area of spiritual leadership.

Third, Loveless (1984, p. 46) implied that impacting the spifitual lives of students was also dependent on the principal's visibility in chapel worships. in resident hall worships (in boarding schools), and by a willingness to be actively involved in the spiritual life of the campus. He added that principals' influence was also contingent on their ability to clearly articulate personal convictions in committees and in private conversations when matters of 11 festyle, values, and spiritual life were at issue. 
Fourth, McDermott (1975, p. 49) suggested that principals could nurture student spirituality by sharing with students their personal experiences of spiritual journey. He argued that the act of sharing openly with students would not only bond both parties in a mutual quest for greater spirituality but would also provide students with the clearest evidence of a principal's walk with the Lord. It would seem, then, that as students see and hear the spiritual journey of another, they grow in their understanding of their own spiritual journey. Finally, Bennis \& Nanus (1985) and Morphet, Johns, \& Reller (1982) discussed a number of strategies of leadership style. In a study of 90 leaders, Bennis \& Nanus (1985) discovered four areas which were fundamental to effective leadership: (1) vision which provided ax organization with a sense of purpose and direction; (2) communication which creates meaning for personnel and helps them become aligned to organizational goals: (3) trust which ensures accountability, predictability, and reliability: and (4) personal initiative which manifests itself in enthusiasm for people, spontaneity, imagination, and a willingness to learn from others. Similarly, Morphet et al. (1982) suggested that initiating change was dependent on a number of important leadership principles. They included: democratic leadership style; a strong sense of group belongingness; satisfaction of individual needs: 
open environment of communication without fear of reprisal: and participation in goal setting, implementation, and evaluation.

In summary, the principal's spirituality refers to the depth of relationship the principal has with Christ and the extent to which he/she assumes the role of spiritual leadership in the school. The sature and phtlosophy of Christian leadership was discussed as a function of five aspects: the call of God, servanthood, followership. transformation, and prayer life and Holy Spirit empowerment. The literature suggested that a school principal was able to nurture student spirituality in a variety of ways: nurturing faculty spirituality, exemplifying a life of devotion to God, visibility and invoivement in the spicitual iffe of the school, sharing personal experiences of their spiritual journey with students, and adopting a number of leadership strategies which will specifically enhance spiritual growth.

\section{School Curriculum}

The school curriculum, according to Chadwick (1982, p. 82), may be defined narrowly as the courses offered, or broadly as all the experiences offered, or the particular experiences of a given student while in school. Similarly. Akers and Moon (1980, p. 20) defined curriculum in terms of the formal curriculum, that which is taught through formal course work, the informal curriculum, that which is taught 
through learning experiences which are not part of the formal curriculum, and the hidden curriculum, which is taught unintentionally through either the formal or informal curriculum. These divergent definitions highlight the broad range of the school curriculum to the educative process. From a christian perspective it underscores the importance of the curriculum as a primary medium of student spiritual nurture. It suggests that every facet of the educative process has the potentlal for enhancing a student's relationship with Christ.

Before attempting to identify from the literature the primary ways by whlch curficulum enhanced student spirituality, it should be noted that there were educators who argued against the ldea of a Christian curriculum. Hirst (1974, p. 77 ) stated that Christian education was a contradiction in terms. He argued:

In particular, there has now emerged in our society a concept of education which makes the whole idea of Christian education a kind of nonsense. From this point of view, the idea that there is a characteristically or distinctively Christian form of education seems just as much a mistake as the idea that there is a distinctively Christian form of mathematics, of engineering, or of farming.

Hudson (1973, p. 189) also argued that Christian schools often treated religious instruction as a separate identifiable part of the curriculum, thereby implying that religious education did not extend to the rest of the curriculum. Advocates of Christian education were also well aware of these problems. The Rt. Rev. Mark J. Hurley 
(í̄ón, p. 102), in a commentary on the "Declaration on

Christian Education" of Vatican Council II, made a forceful plea for a reappraisal of Catholic education which had "mimicked their secular counterparts, credit for credit, course for course, without the pervasive influence of the Catholic mind." He raised the pointed question. "If there be no specific difference, then why and wherefore the Catholic college?"

In response to this question, Christian educators argued for the distinctive nature of the Christian school on the grounds that spiritual nurture was not merely confined to the content of a particular course of study but rather it penetrated the whole educative process. Thiessen (1985, pp. 48-50) explained this by enphasizing the importance of the role of "presuppositions," or "first order principles" in the curriculum.

They influence belief systems subjectively by way of interpreting reality. . . . The relationship between first premises and the rest of scientific knowledge cannot be represented in terms of logic. but it is nonetheless significant. These first premises are acquired unconsclously via the language a child learns or by the unconscious imitation of adults.

Similarly, Knight (1980, pp. 195-196) argued that

Authentic and viable curricula must be developed out of and be consistent with their metaphysical and epistemological bases. It is therefore a foundational truth that different philosophical approaches will have different curricula.

Knight (1980) also pointed out that Christian curricula should not be a readjustment or an adaptation of secular 
curricula but rather should reflect the unique character of Christianity.

The literature suggested four important propositions of Christian educational philosophy essential for Christian nurture which should undergird all curricula. The first was the concept that "all truth is God's iruth." Initially put forward by Augustine in Christian Education and subsequently developed by Gaebelein, this proposition suggested that all truth in the Christian curriculum, whether it dealt with nature, man, society, or the arts, must be seen in proper relationship to Jesus Christ as Creator and Redeemer (Gaebelein, 1968, p. 22).

A second proposition was that the Bible, as the insplred revelation of God, was the foundational and contextual document of the Christian curriculum. While much truth existed outside scripture, no truth existed outside the metaphysical framework of scripture. Holmes (1975, p. 26) argued that the teaching authority of Scripture provided an interpretive framework of how everything related to God.

A third proposition was that the integration point for all Christian educational effort was Jesus Christ. According to Walworth (1981, p. 286). Christ should be the center of the Christian curriculum. Walworth (1981) argued that because Christianity was Christ, the Christian curriculum must be centered on Him if the goal of Christlikeness was to be realized. If anything took the 
place of Christ as the central focus, then it was likely that the school had lost its Christian perspective. The fourth proposition was that the nature. condition, and needs of the student should be the focal point of the curriculum and the educational process. According to Sanderson (1979, p. 16), the curriculum should reflect the redemptive nature of Christian education where ever: $;$ student was viewed as having infinite worth before God, and where the greatest need of each student was to enter into a saying gelationship with jesus christ.

In summary, the school curriculum encompasses the whole educative process: the formal curriculum, the informal curriculum, and the hidden curriculum. Every facet of the curriculum has the potential to enhance student spirituality. Some educators believe Christian education to be a contradiction in terms. Alternatively, Christian theorists have emphasized the broader nature of the curriculum as well as the distinctive nature of Christian philosophical presuppositions which penetrate the whole educative process. Accordingly, theorists Identified and discussed four presuppositions essential for Christian nurture. They included: ald truth is God's truth; the Bible is the foundational and contextual document of the curriculum; the integration point for all Christian educational effort is Jesus Christ; and the nature, condition, and the needs of the student should be the focal point of the educational process. 


\section{Teaching Methodology}

Teaching and learning methodology, according to

Byrne (1977, p. 185), included "those devices and processes which facilitate the teaching-learning process, culminating in knowledge, habits, attitudes, and ideals." Haburn (1981, P. 179) suggested that

methods are instruments (tools, vehicles, activities, or processes) that a teacher utilizes in leading a student through a learning experience that causes the learner to change and grow.

It would seem that if teaching methodologies are the means for the acquisition of knowledge, attitudes, and skilis, and for bringing about change and growth in the learner, then they are of special importance for the Christian educator. According to Sanner \& Harper (1978. p. 187), methods were the means for understanding and communtcating the content of "truth." Byrne (1977, p. 191) stated:

The aim or Christian education is to see God revealed; the goal of Christian education is to qualify man to reveal God. Method is the means by which these are accomplished.

While there were differences in opinion among secular educators regarding the relationship of method and curriculum (content) and which was of greater importance in the educational process, Christian educators advocated the importance and inseparabllity of the two aspects. They regard both as integral to meeting the goal of Christ-like character (Bryne, 1977, pp. 185, 191). 
Yet it was clear from the literature that before the methodological devices or instruments bring the desired change and growth, it was necessary to recognize that they must be consistent with the educational presuppositions of the reaching and learning context. According to Priester (1966, pp. 61-62),

The educator faces the ever-persisting problem of selectivity of ideas and descriptions that are deemed by him to be true and worthy of commitment. Therefore, any valid theory and practice of Christian education must take into account philosophy as well as other disciplines that deal significantly with the human scene.

The goal of the more traditional philosophies was the transfer of cognitive knowledge with much emphasis on indoctrination, memorization, drill, and testing for learned facts. By contrast, the goal of the more modern philosophies was to enable the student to gain personal and environmental insights from first-hand experience. Such philosophies stressed the experiential methodologies of discovery, creative skills, self-pacing, building a positive classroom environment, and understanding the individual (Braley, 1978, pp. 98-99). While not attempting to diminish the value of the methodological techniques of the traditional or more modern philosophies, Fakkema (1952. p. 97) argued that without a Christian philosophical foundation, such philosophies and their associated methodologies have a strong humanistic thrust. He argued that they reflected a human-centered rather than a Godcentered approach to learning. He contended that without a 
theistic center, "such education leads to subjectivism, relativism, and moral delinquency."

According to knight (1980, p. 213), the goal of

Christian education went beyond the accumulation of cognitive learning, self-awareness, and coping with the environment. He argued that while it included these aspects, it had a more overriding goal of nurturing student spirituality and fostering Christian-character development. He argued that "the methodologies utilized by the Christian educator must take this pre-eminent purpose into consideration." He acknowledged that while this inevitably included many if not all of the same methods used in other educational settings, Christian teachers would "select and emphasize those methodologies which best aided them in helping their students to develop Christ-like character." It would seem, then, that as teaching and learning methodologies is a cliristian school correlate with Christian philosophy, they are likely to have a greater and more lasting impact on the spiritual lives of students. According to Sanner \& Harper (1978, p. 213), "the divinehuman partnership of Christian teaching" was dependent not only on human lives which were committed to Him but also on human methods which were dedicated to achieving His purposes.

Given this philosophical basis for Christian teaching/learning methodology, the literature presented a number of important guidelines for nurturing Christian 
growth. First, Byrne (1977, p. 193) suggested that the Christian approach to truth should not only include methodologies of reason and experience but strategies that also utilized the primary sources of divine revelation. Second, Knight (1980, pp. 214-216) stressed that methodologies need to be directed towards enhancing "selfcontrol" and the internalization of principles. relationships, and Christian values. He argued that "the essence of Christian education was to enable students to think reflectively for themselves" in order to foster moral maturity and Christian growth.

Third, White (1952) stressed the need to employ methodologies which reflected a personal concern for each student and which accommodated student individuality. H1lde $(1978 / 79)$ suggested the need to personalize all teaching effort, to provide positive reinforcement for each student, and to accommodate individual differences among students.

$$
\text { Fourth, Johnson \& Johnson (1975, p. vi) advocated }
$$
the need to adopt a goal structure and a methodology which fostered cooperation rather than competition in the classroom. They argued that while research on the effects of competition in cognitive learning were mixed, the evidence clearly showed that cooperation was superior to competition in producing desirable affective learning and helping students develop interpersonal skills. 
Rinally, Wear $(1990 / 81)$ and Shelton (1983) stressed the need for methodologies to reflect the readiness of students in terms of their cognitive, moral, faith, and emotional development. Shelton (1983, p. 113) stated that "the spiritual growth of the young person is only realized when all facets of the adolescent's life are exposed to the call of Jesus."

In summary, teaching and learning methodology may be defined as the means of facilitating the teaching/learning process that brings about goal realization. Educational theorists argued that if goals were to be realized, the methodology must be consistent with the educational presuppositions of the teaching/learning context. While Christian educational practiced inevitably included many if not all of the same methods usta in other educational settings, the Christian teacher should select and emphasize those methodologies which best aided in nurturing student spirituality and Christian-character development. In nurturing spiritual growth, the literature suggested that teaching/learning methodology should incorporate revelation, reason, and experimentation; culitivate reflective and independent thought; personalize teaching effort; encourage cooperation rather than competition; and reflect the cognitive, emotional, and moral readiness of students. 
School Discipline

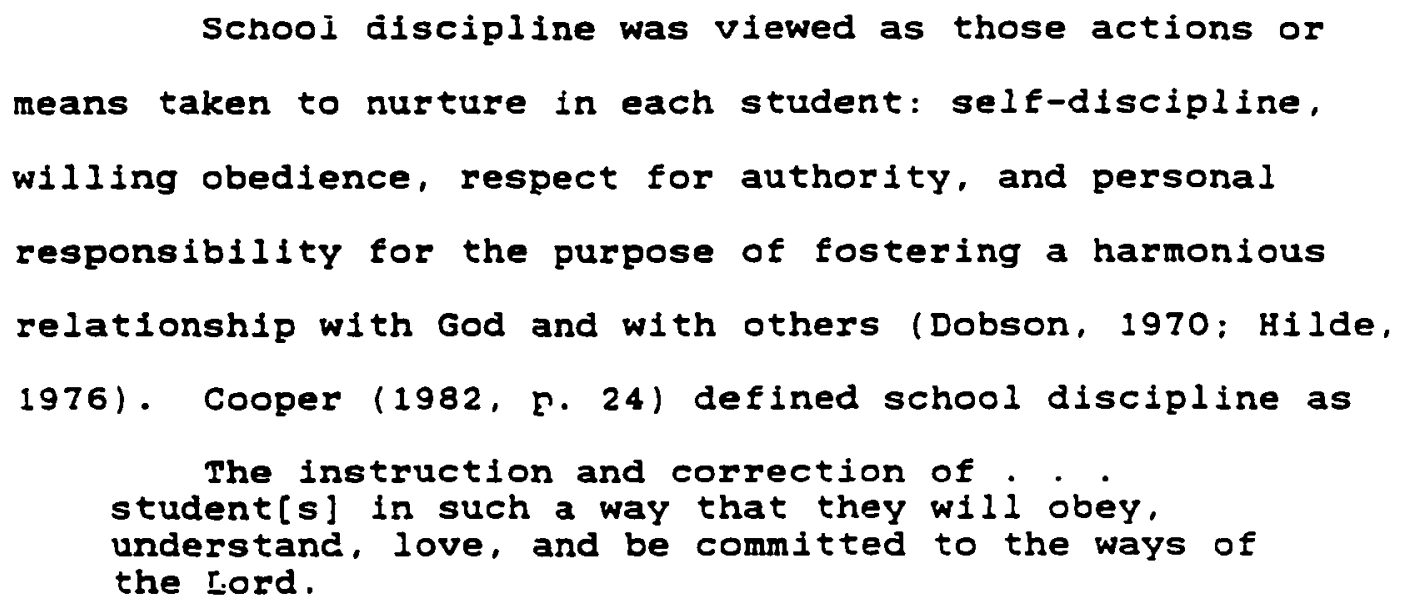

This work is the nicest, the most difficult, ever committed to human beings. It requires the most delicate tact, the finest susceptibility: a knowledge of human nature, and a heaven-born faith and patience, willing to work and watch and wait. It is a work than which nothing can be more important.

The nature, philosophy, and goals of discipline were variously explained. At one extreme was the "permissive philosophy" which suggested that discipline is unnecessary. Neill (1960), a chief proponent of this philosophy, advocated the establishment of an open school 
environment where students could be free to behave ss they chose. At the other extreme was the "autocratic philosophy," best illustrated by military school and the imposition of military will on the individual. Both extremes are at variance with the nature, philosophy, and goals of Christian discipline.

Zais (1976, p. 245) suggested that theories of learning (including disclpline) rest on the investigator's presuppositions and conception of the nature of man. Central to Christian philosophy was the realization that human beings have been created in the image of God with the ability to think and choose for themselves. White (1952, pp. 288-289) suggested that a person's individuality was a Eunction of mind and will. She added that "the will is the governing power" in the human being, "the power of decision or choice." As a consequence, she argued that "the mind should be guided and molded, not ignored or crushed." This suggests that personal self-control, brought about by the internalization of the Christian ethic, is the goal of Christian discipline.

This has important implications for the exercise of discipline in a Christian school. First, there is a need to articulate the philosophy and goals of school discipline to students. According to Hilde (1976, p. 14), one reason for the difficulty encountered in working towards the goal of student self-government was the lack of purpose and direction in the school disciplinary process. He argued 


\section{$+?$}

that student growth was impaired because school discipline was erratic and inconsistent. Canter (1982, p. 16) also advocated the need for a "systematic plan of action" to ensure the well-being of both student and teacher. He argued that guidance, direction, and limit-setting boundaries were important factors in the emotional wellbeing of students.

Second, the learning theory and the motivation techniques adopted to foster appropriate behavior should reflect the goal of "Internalization" of moral principles and Christian values. According to Dobson (1970, p. 49), one of the most significant learning theories to have been proposed was Thorndike's "Law of Reinforcement" (sic). Dobson (1970) advocated behavioral reinforcement (reward system) as a means of cultivating self-control and fostering internalization in young people. Opponents of "operant conditioning" contended that reinforcement and reward constituted bribery. They argued that unrewarded behavior that resulted from intrinsic motivation was to be preferred to behavior that was dependent on extrinsic motivation. According to Lepper \& Greene (1975, pp. 484485), a system of extrinsic incentives might undermine the Intrinsic interest and even decrease performance. Yet Gage \& Berliner (1984, p. 4i4) took the position that the reward system for motivating behavior was effective when used judiciously. Recognizing the developmental nature of moral maturity (self-control), the Christian educator, while 
disagreeing with the underlying presuppositions of "humanistic determinism," might adopt extrinsic motivation techniques in an effort to lead to increasing intrinsic motivation and internalization.

Third, behavior-modification techniques should be founded on the principles of love and justice. The literature focused on three approaches to behavioral problems. The first was the noninterventionist view advocated by Rogers (1969), Moustakas (1972), and Gordon (1975). This view was based on the assumption that children were innately good and that they should be in control of their own behavior. In sharp contrast was the behaviorist position advosated by Homme (1970). Axelrod (1977), and Blackham \& Silberman (1975), which placed major responsibility for the solution of the problem on the teacher. A third contrast was the interactionist position which attempted to teach students to solve their behavioral problems as a means of enhancing self-discipline. This view, advocated by Ernst (1972), Freed (1973), and Glasser (1969), stressed the guidance function of the teacher and emphasized that rules were not ends in themselves but means toward teaching students to solve their own problems. This latter view was closely aligned with the Christian approach. Supporting a similar position, Dobson (1970) remarked that loving care and guidance of young people necessitated "firm control," while Canter (1982) advocated 
73

the need for "assertive discipiine" which, he argued, involved caring interaction and guidance of students.

The literature focused on a number of specific ways that school discipline was able to nurture student spiritual growth. The first focused on the manner, speech, and the approach of the teacher and/or administrator. According to Brophy (1977), and Brophy \& Putman (1979), it was discovered that teachers who were cheerful and friendly, who remained calm in crises, who listened activeiy without being defensive, and who accepted and respected each student as an individual were more effective in nurturing student growth.

second, the school and classroom climate was also a factor in nurturing Christian growth. According to Johnson \& Johnson (1975), organizational patterns which result in students feeling capable and secure seemed to produce students with greater maturity. Wood, Nicholson, \& Findley (1979, pp. 236-237) also suggested that a school envirouinest in which respect, responsibility, trust, and personal honor were integral was likely to enhance student self-discipline.

Third, the approach to the development and implementation of school rules was found to have an important bearing on student growth. According to white (1952, p. 290), learning to respond to God in obedience necessitated learning the importance of obedience in the home and the school. She argued that rules should 
represent the voice of the school, they should be few and systematically enforced.

Fourth, effective communication, especially during times of punishment, was also found to have an important impact on student growth. Glasser (1969) distinguished between discipline and punishment by suggesting that "discipline" was directed at the objectionable behavior while "punishment" was directed at the person. White (1952, p. 292-293) stated:

The true object of reproof is gained only when the wrongdoer himself is led to see his fault and his will is enlisted for its correction. When this Is accomplished. point him to the source of pardon and power. Seek to preserve his seif-respect and to inspire him with courage and hope.

In summary, school discipline is viewed as those actions or means taken to nurture self-discipline in each student for the purpose of fostering a harmonious relationship with God and others. Nurturing such a relationship necessitates first understanding the nature, philosophy, and goals of Christian discipline and their methodological implications, and second, understanding ways school discipline can enhance Christian growth. Factors involved in nurturing growth included: the manner, speech. and the approach of the teacher and/or administrator: the school and classroom climate; the development and implementation of school rules; and communication. especially during times of punishment. 
Teacher spirituality

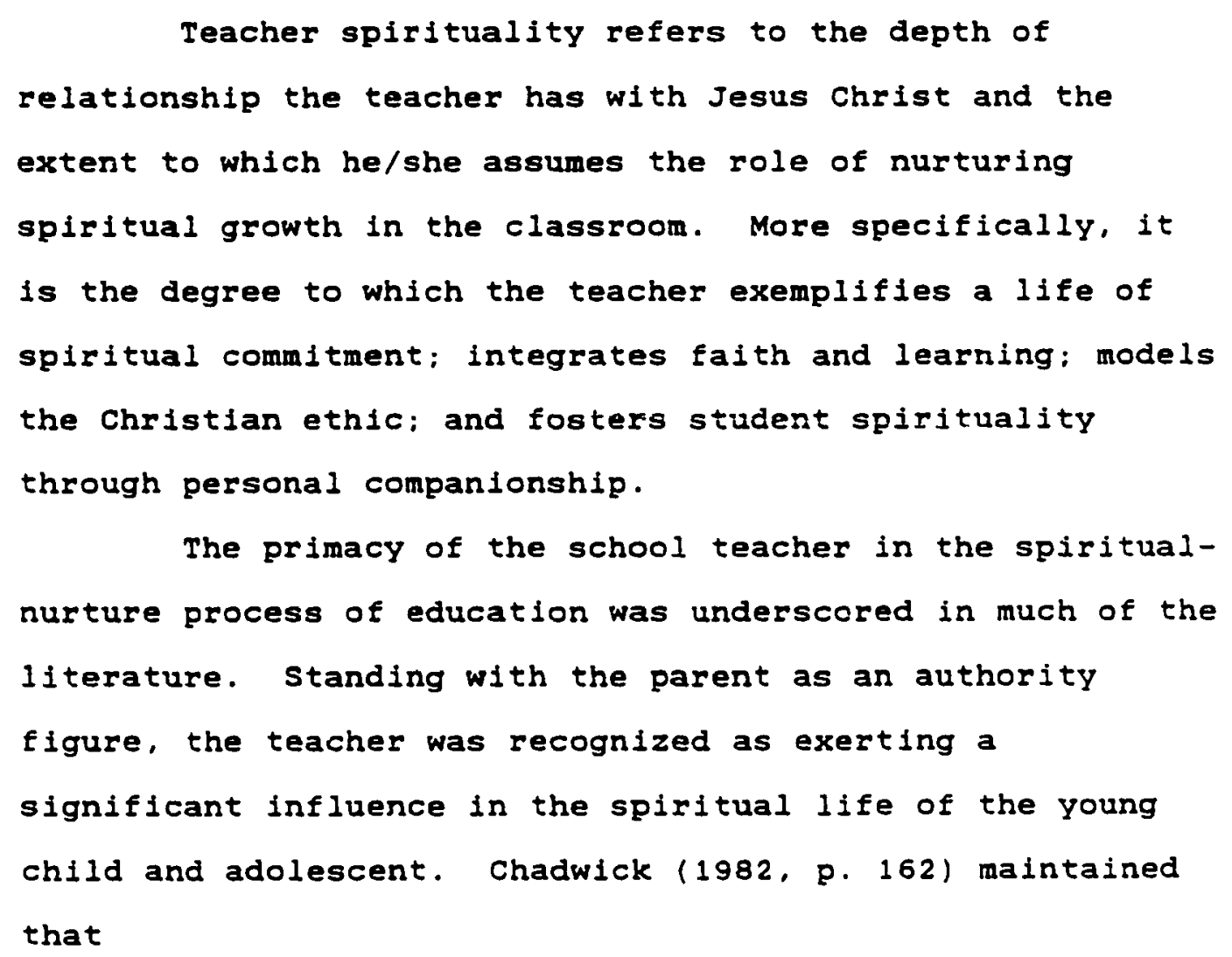


spiritual nurture of students in Catholic schools. Barrett (1979, p. 2) stated that "our greatest asset.. . is the shining witness of the reacher," while geterson (1981, p. 80) later argued that teachers were not only necessary in the perpetuation of Christian faith, they are "indispensable." The implication of the significance of the Christian teacher to spiritual nurture, according to Chadwick (1982, p. 169), was the necessity for teachers to be uniquely prepared to meet the demands of their calling to Christian ministry.

The philosophical nature of the christian teaching ministry, according to the Nc: Testament, is one of divine appointment and is a ministry of reconciliation. Teaching is a divine calling (Eph 4:11; 1 Cor 12:28; Rom 12:6-8) and has a pastoral function $(1 \operatorname{Tim} 3: 2)$. Elaborating on this biblical position, Buckley (1977, p. 6) stated that teachers were "engaged in a form of ministry or service" in that their role was one of leading young people into a personal relationship with the Lord. Commenting on the "restorative nature" of Christian education, Hill (1982, p. 124) viewed the Christian teaching role also as "a ministry of reconciliation."

The literature suggested four ways a teacher's life could be influential in nurturing student spiritual growth. First, the influence of teachers' lives was in direct proportion to their own personal relationship with the Lord and the extent to which their lives were spirit-directed. 
According to Eavey (1954, p. 61), those who minister in Christian education "must have in themselves the life of Christ and be possessed by the Spirit of God." Elaborating on this same theme, Bushnell (1947, pp. 44-45) counselled the Christian educator:

. . . the Life of God must perpetually reign in you. . . . It must be seen and felt with them that religion is a first thing with you. And it must be first, not in words and talk, but visibly first in your love, or that which fixes your aims, feeds your enfoyments, satisfles your wants, contents your ambitions, beautifies and blesses your character. . .

According to Barrett (1979, p. 8), such a connection was contingent on the prayer life of teachers and their willingness to share their faith. However, Peterson (1981, p. 82) warned:

It has often been said that we communicate more by what we are than by what we say. A person's innermost being will not be hidden very long from the observing. searching eyes and ears of students. A phony faith will not stand the test.

A second way a teacher's life was influential was by communicating with a Christian mindset, or what Blamires (1963) referred to as "The Christian Mind." In this respect, H1ll (1982, P. T) stated:

The Christian mind is one which has distinctive starting points. It is not enough that we love christ and think humanistically. We must also think as Christ thinks, deriving our presuppositions from His teaching rather than from current philosophical thought and the spirit of the age. This means that we must come to terms with the eternal insights which we believe to be recorded in the Bible. 
Braley (1978, p. 115) also emphasized that a Christian mind was a "biblically-orientated mind" where bitilcal

principles were exemplified in dally living. Speaking of the impact that a teacher's personal philosophy of life had on students, Gaebelein (1968, p. 37) stated that the "world view of the teacher. . gradually conditions the world view of the pupil."

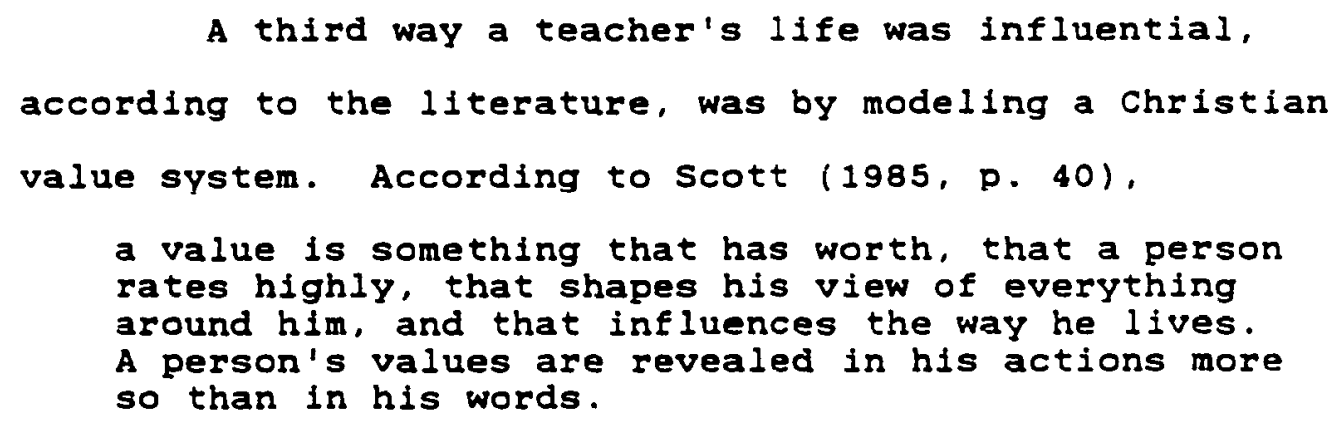

A fourth way a teacher's life was influential in

nurturing student spiritual growth was by cuitivating a personal relationship with students. Flynn (1985, p. 164) 
stated that "students unconsciously modeled their relationship with God on the patterns of relationships which existed in the social milieu." In discussing the alienation of teenagers from religion, Dudley (1979, p. 7) suggested that improving the quality of the relationships between adolescents and their parents and teachers was likely to enhance adolescent receptivity to religion. Shelton (1983, pp. 16-18) implied that the relationship between the teacher and student was dependent on the availability of the teacher, the acceptance accorded the student, the teacher's expression of authenticity, and the degree of teacher vulnerability.

In summary, teacher spirituality refers to the depth of relationship the teacher has with christ and the extent to which he/she assumes the role of spiritual leadership in the classroom. The primacy of the Christian teacher in nurturing student spiritual growth was underscored in much of the literature. While the philosophical nature of the Christian teaching mintstry was one of divine appointment and was a ministry of service, its chlef goal was one of leading students into a personal relationship with the Lord. The literature suggested four ways a teacher's ife was influential in nurturing student spiritual growth: living a Spirit-directed life, thinking and communicating through a christian mindset, modeling a Christian value system, and cultivating a personal relationship with students. 


\section{School Worships}

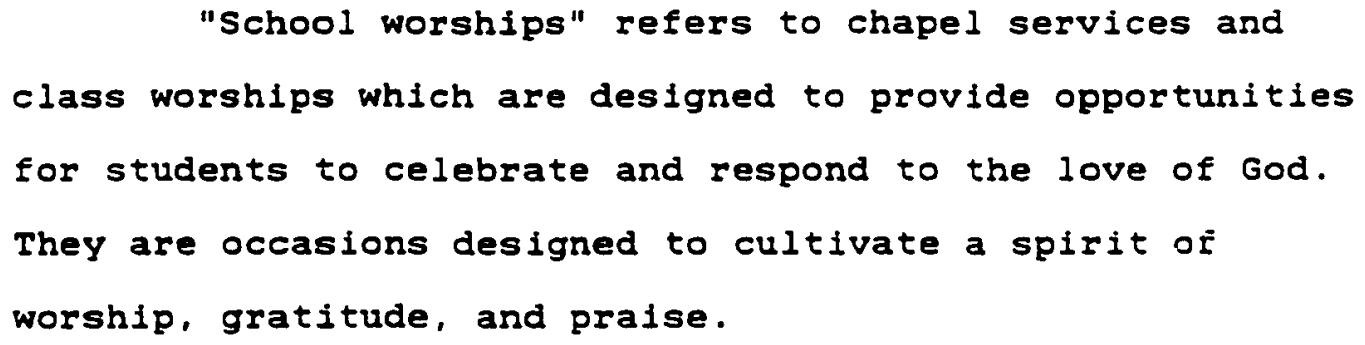

The importance of worship experiences to spiritual growth was borne out in the literature. White (1948, vol. 6, p. 174) stated:

of all the features of education. . . the religious exercises are the most important. They should be treated with the greatest solemnity and reverence.

More recently, Stone (1985, p. 129) suggested that "a spiritual growth program without worship was like an orchestra without music." While this generally reflected the attitude of many Christian authors, the emphasis differs and was reflected in the reasons given for its importance to spiritual growth. Underhiii (1936, p. 17) emphasized that responding to the call to worship was important because it lead to union between creator and creature. She stated:

Worship. . is an avenue which leads the creature out from his invenerate self-occupation to the knowledge of God, and ultimately to that union with God which is the beatitude of the soul. . .

Astley (1984, p. 245) argued in favor of the importance of worship by suggesting that it "sustains, deepens, and evokes religious experience." She argued that religious experlences of worship helped worshipers to learn "about 
the nature of religious reality." Similarly, Massey (1985, p. 104 ) added that worship was important because it meets the need of "universal affiliation." In worshiping together, each worshiper was able to draw strength from others.

Notwithstanding the importance of worship to spiritual growth, the literature seemed to suggest a tension in the nature of worship. Some insisted that worship and learning were two distinct events and must never be coupled. They feared that a coupling of the two contributed to the erosion of worship as worship and made it nothing more than an educational event. Astley (1984, p. 244) maintained that "worship is an end in itself." While there might be some legitimacy in this position. Astley ignored the undeniable fact that there was a learning dimension in worship. By contrast, Gobbel (1979, p. 573) suggested that the impact and contribution of worship for Christian nurture and growth might "far exreed and outstrip all other aspects of formal Christian education." Gobbel (1979) argued that worship "educates for good or evil" through the shared experiences of the worshiping community.

The literature identified a number of ways school worships were able to nurture student spiritual growth. According to Devnich $(1981$, p. 8), the first and most critical, because it undergirded all worship experiences, was the need for worship to be Christ-centered. He argued 
that only as students encountered the risen Christ were they able to grow into His likeness.

A second way student spirituality might be enhanced, according to the literature, was through the active involvement of faculty and students in school and class worships. Gaebelein (1968, p. 94) argued that if the integration of faith and learning were to be a reality, then the involvement of every member of the faculty together with student representatives was a necessity. Stone (1985, p. 131) belleved that spiritual commitment and growth were functions of personal involvement. According to Richards (1975, p. 285),

When a sense of unity and identification has been established. . . particlpation in worship and responding to the Word becomes a powerful means of transformation of the individual.

A third way worship experiences might enhance spiritual growth was to ensure relevance and flexibility in worships in order to meet the emotional needs and the changing developmental concerns of students. Massey (1985. p. 93) argued that if students were to be challenged by scripture, then every attempt must be made to ensure that worship experiences had "meanings that can be voiced with considered understanding and emotional involvement." Fairchild (1985, p. 39) stated the necessity to be flexible so as to adapt to the unexpected. He argued that meeting the emotional needs of students enabled them to see relevance in Christianity. 
In summary, school worship refers to chapel services and class worships which are designed to provide opportunities for students to celebrate. These worships were considered important to spiritual growth because they were seen as a response to the divine call to worship: they evoke and sustain religious experience; and they meet the need of "universal affiliation." The literature suggested a tension in the nature of worship between those who insisted that worship and learning were two distinct events and those who believed they were inevitably coupled together. Notwithstanding this tension, three ways school worship could nurture student spiritual growth included: centering on the Gospel of Christ, involving both faculty and students, and ensuring relevance and flexibility in worship experiences.

\section{Community Service Outreach}

Community service outreach activities cultivate student consciousness of community needs and provide opportunities for students to serve other people as an outgrowth of personal faith.

Theorists have argued that the central aim of Christianity was service. According to Shelton (1983, p. 294), there was a direct relationship between spirituality and social commitment. The call to discipleship was a call to service. He stated that "living the Gospel demands social commitment." Heyboer (1980, p. 
26) also contended that the real purpose of Christian discipleship was to be a "witness" to the saving faith of Jesus.

The literature suggested that service outreach enhanced spiritual growth. Carey (1977, p. 20) emphasized that "learning to serve and to exert influence empowers students as persons:" while Anne (1980, p. 25) stated that "faith-in-action" enabled young people to grow. Voskuil (1982, p. 14) argued that involvement in community service and outreach activities helped young people to reaffirm their Christian values.

Notwithstanding its importance, there was debate in Christian educational circles as to the appropriate balance between nurture and evangelism in Christian education. According to Richards (1975, pp. 120-121), the "evangelistic thrust" tended to focus on evangelism with the belief that spiritual growth would automatically take place, while the "nurturing thrust" tended to focus on discipleship with the belief that evangelism would automatically take place. Richards (1975, p.122) took the latter position by suggesting that a "nurturing thrust" assures a growing maturity which will naturally express itself in the communication, and reproduction of God's life in others through the living communication of His Good News.

According to Knight $(1980$, p. 222), the "conservative function" of Christian education was twofold: to pass on the legacy of Christian truth and to provide a nurturing 
protective atmosphere for the transmission of Christian values. While knight recognized the importance of the "conservative function" of Christian education, he also believed the "revolutionary fuiction" to be extremely important because it educated Christian young people to become evangelistic witnesses to the love of God. Knight (p. 225) noted that the function of the Christian school in essence was to educate the young for service. While both schools of thought might differ in their emphasis, it would seem that both aspects were important for the purpose of what White (1952) refers to as "complete education." In view of the importance of this dimension, Christian educators have identified two primary goals of a school community service outreach program. The first goal, according to Voskuil $(1982$, p. 14), was the need to translate the Christian world view into a life of service to others. Specifically:

It is the Christian school more than any other institution, but with close support of church and home, that must deal with the gospel as a world view and then translate world view into a way of life. It must get the Christian vision of life out of the closet and into the market place. . . . The Christian school has both a challenging responsibility and a strategic opportunity.

The second goal, according shelton (1983, p. 300), was the need for Christian educators to nurture adolescent social consciousness. Shelton (1983) argued that because adolescence was a period of social awakening characterized by an increased consciousness of social issues and social 
justice, it behooved educators to provide opportunities for community service as a means of nurturing Christian discipleship.

The literature identified a number of important strategies for translating the Christian world view into a life of service. The first strategy was the need to cultivate an open environment of sharing in the school. Devnich (1981, p. 41) suggested that witnessing outside the school was contingent on the degree of freedom that students had in shari.zg Christ at school. He argued that it was futile to organize religious activities unless there was a good deal of "real Christian fellowship" between teachers and students.

The second strategy was the need to incorporate a :ide range of service projects and activities in the school curriculum. Morgan (1986, p. 17) suggested that "a program of interaction, service, and outreach" should be built into the school curriculum with specific activities in each discipline. Morgan (1986) suggested allowing the student Association in conjunction with faculty to organize projects involving the entire student body. Anne (1980, p. 23) advocated that full semester courses should be designed to involve students in community service. Similarly, Manspeaker (1985, p. 6) suggested that in curriculum plenning, a wide range of opportunities should be presented to students so they could choose the activities of greatest interest to them. Commenting on the 
Q?

virtue of student involvement, Manspeaker (1985) stated that growth was more likely to result from experience than through counsel.

The third strategy was the need to invite community personnel into the school. Carey (1977, p. 20) suggested that "persons who were service models" should be invited to visit classrooms and to discuss their programs. Using similar personnel in career education was also likely to enhance student awareness of the service opportunities. Fourth, there was a need to adopt strategies which nurture social consciousness. Shelton (1983, pp. 311-316) suggested focusing on the social interaction of Jesus, reasoning deductively about social problems, exposing adolescents to social injustice as a means of creating a communal environment which models christian values. In summary, community service outreach refers to the activities undertaken in a school program to cultivate social consciousness and a commitment to serve as an outgrowth of personal faith. Theorists argued that while the central aim of Christianity was Christian service, it was also important because it enhanced spiritual growth. Yet there was debate as to the appropriate balance between nurture and evangelism in Christian education. Notwithstanding this debate, a number of important strategies which were suggested for nurturing spiritual growth included: cultivating an open environment of sharing in the school, incorporating a wide range of service 
projects and activities in the curriculum, inviting

communty service personnel into the school, and adopting strategles which specifically nurture social consciousness.

\section{Bible Teacher Spirituality}

Bible teacher spirituality refers to the depth of relationship the classroom Bible instructor has with Christ and the extent to which he/she is committed to leading students into a similar relationship. It is the degree to which the religion instructor exemplifies a life of spiritual devotion to God, provides spiritual leadership in and out of the religion classroom, and cares for the spiritual well-being of students.

The importance of the role of the Bible teacher in the spiritual nurturing process was often alluded to in the literature. According to stone (1985, p. 24), student interest in spiritual things was largely a function of the Bible teacher's spirltuality. Drawing from his own experience, he stated:

When spiritual disciplines became an integral part of my life. I noticed that the youth were more interested in what I had to say and it seemed that what I said had more credibility.

Similarly, in a report on competencies in a self-evaluation study for religion teachers, Shields (1974, p. 17)

suggested that the spiritual impact of any religion program was directly related to the spiritual qualities of the teacher. Kainer (1984, p. 35) even suggested that the effectiveness of the work of the Holy spirit in the 
classroom was often a function of the Bible teacher. He stated that "the Divine Teacher can be hindered or limited by the attitude of the classroom Bible teacher." Gallagher (1982, p. 34) also underscored the importance of the Bible teacher's role by suggesting that while the spiritual dynamics of teacher-student relations apply in every classroom, they should be of spectal concern to the Bible instructor. According to him, the Bible teacher's prime responsibility was one of facilitating the "divine-human relationship." He suggested:

Dealing overtly with the divine-human relationship, the Bible teacher has an enormous opportunity to impart to students the ideas of spiritual success of spiritual failure. (p. 34)

While the importance of the role of the Bible teacher was often stressed, Gaebelein (1968, pp. 48-53), in the interests of "integrating faith and learning." challenged the practice of specialized Bible teachers and separate Bible departments. He argued that with a separated Bible department, religion often becomes isolated from other studies. He stated:

Instead of being organically united with the classes in mathematics, literature, science, or history they are effectively insulated from them. (p. 48 )

He believed that Christian teachers needed to be competent not only in their own specialty but also in the teaching of the Bible. He felt that if a true integration of faith was to take place in the "secular" fields, then each teacher needed to be immersed in scripture to such a degree that 
competence in Bible instruction would be a natural corollary.

While it is undoubtedly true that Christian teachers need to be immersed in Scripture and to be so acquainted with the Savior that they can truly integrate their subject fields with scripture, a case for Bible teaching specialists and a separate Bible department has also been argued convincingly. As stone, Shields, Kainer. \& Gallagher implied above, quality Bible teaching which was effective in meeting the developmental needs of young people, required specialized training, skills, and competence as well as creative thought and effort. It would appear that the rime demands of such a responsibility necessitated specialization.

According to the literature, there were three ways in which the Bible teacher's life was especialiy influential in nurturing student spirituality. The first was through their own life. A Blbie teacher's spiritual life was likely to have a significant impact on the spiritual life of the student. According to Betts (1910, p. 18), the authority of religion teachers rested on their religious experience. He stated:

The best definition of religion we can present to the child is the example and warmth of a life inspired and vivified by contact with the source of all spiritual being.

Bushnell (1947, p. 318) belleved that before children could recognize meaning and relevance in the spiritual realm they 
must first see its meaning and relevance modeled in the Iife of adults. He suggested that "truth must be lived into meaning, before it can be truly known." Second, Bible teachers' lives were especially influential through their attitudes towards and their relationship with students. In a review of the research on the teaching of affective responses, Khan \& Weiss (1973, p. 759-804) suggested that the teacher was one of the most important influences in the development of affective responses. Commenting on this review, slattery (1974, p. 672) argued that because the teacher of religion aimed at more affective than cognitive responses in their students, it followed that
A warm, friendly, sympathetic and understanding religion teacher is more likely to have a positive influence on the students' religious responses than one who is cold, distant, and unaware of students' needs.

$$
\text { According to Manspeaker (1985, p. 6), a Bible }
$$

teacher's role in cultivating an affirming relationship with each student provided a basis for nurturing a relationship with God. stone (1985, p. 98) suggested that adults relationships with young people would prove to be one of the most important factors in the young people's spiritual growth. He argued that a relationship with God was only understood in the context of meaningful relationships with other people. Link (1982, p. 509) argued that Bible teachers must be people who cared deeply about the spiritual well-being of students. He stated that 
"it must be urmistakably clear to students that they respect them, appreciate them, and love them." Knittle (1981, p. 42) even suggested that religion teachers should be replaced if they were not "people orientated."

Third, a Bible teacher's life was especially influential in the spiritual growth of students through their role as spiritual counselors. According to shelton (1983, p. 180-183), the nurturing impact of spiritual counselling on adolescents was contingent on four considerations. The spiritual counselor must first understand the social, emotional, intellectual, moral, and faith dimensions of adolescence and the developmental issues that accompanied this period of change. Second, there was a need for the spiritual counselor to be able to provide a total perspective that situated the adolescent's current life situation in the context of the past and future growth possibilities. Third, the spiritual counselor must have a sense of "quiet openness." There must be an ability to listen to what the adolescent was saying, to avoid stero-typing young people, and to be perceptive to individuality. Finally, Shelton (1983) maintained that the spiritual counselor also needed to be able to comment in a way that invited young people to reflect on their experiences in the context of how God might be presently working for their good.

In summary, Bible Teacher spirituality refers to the depth of relationship the classroom Bible instructors 
93

have with Jesus and the extent to which they care for the spiritual well-being of students. While its importance was often stressed, Gaebelein (1968), in the interests of integrating faith and learning, challenged the practice of specialized Bible teachers and separate Bible departinents. Given the importance of the Blble teacher, the literature focused on three ways the Bible teacher's life was especially influential in the nurturing process. They included their life of spiritual devotion to God, their ettitude towards and relationship with stulants, and their role of spiritual counselors.

\section{Weeks of Prayer/Spiritual Emphasis}

Weeks of Prayer/Spiritual Emphasis refer to the special occasions made available in the school program to lead students into a deeper relationship with christ and to foster spiritual growth. Lucas (1952, p. 18) defined it as

A series of meetings adapted especially for the purpose of winning the careless and the indifferent among the young and of deepening the spiritual experience of all.

Bornstein (1982, p. 3), on the other hand, defined it more in terms of the occasions given to fostering the need and practice of prayer. Emphasizing yet another aspect. suddarth (1985, p. T) defined it in terms of a "Christian Fellowship Week" designed to enhance spirituality through community and fellowship. For purposes of this study, while the three definitions emphasize different aspects, 
each was considered important to the overall goal of enhancing spiritual growth.

According to Bower (1985, p. 38), no school year was complete without Weeks of Spiritual Emphasis. He argued that "they promote spiritual togetherness," "set a spiritual tone," and "create unity" in the school. olson (1952, p. 16) also suggested that they were of "inestimable value in fostering spiritual life," while Vandeman (1952, p. 19) commented that they were "vital to sustaining spiritual life in our youth." In a different respect, Olson (1955, p. 12) suggested that they were important because "the outpouring of the Holy Spirit" was "dependent on fervancy of united prayer."

The philosophy behind the Weeks of Spiritual Emphasis, according to the literature (Lucas, 1952: Vandeman, 1952; Gaebelein, 1968), was the need to meet two equally important challenges: to lead the non-committed to a commitment (the evangelistic function) and to nurture and strengthen those already committed (the nurturing function). While Gaebelein (1968, pp. 94-98) was an advocate of meeting these challenges, he differed from Lucas and Vandeman in his emphasis. He argued that while there was an undoubted need for evangelism in a Christian school, there was also an important need to minister to those "who are already committed Christians," especially those "who know nefthey the day nor the hour of the 15 conversion." Gaebelein (1968) stressed that nurturing the 
needs of this latter group was equally as important as evangelizing the non-Christian. He felt that the "already committed" were often neglected. While it seemed difficult to separate the two functions and to generalize as Gaebelein (1968) has done, he raised to the surface the need to take students beyond a mere introduction to the Christian gospel and into a deeper, ongoing relationship with Christ.

The literature identified a number of ways in which Weeks of Prayer/Spiritual Emphasis were able to facilitate decisions of Christian commitment and to nurture Christian experience. Pirst, Lucas (1952) as well as Hartman (1952) suggested that the results of renewal and reformation would be proportionate to the amount of prayer and preparation. They argued that not only was careful thought and planning needed in considering the needs of the student body, but of greater significance was the need for fervant prayer for the empowerment of the Holy spirit.

Second, the attitudes of both the speaker and the teachers had an important impact on the results of the week. Vandeman (1952, p. 20) suggested that the presentations and the attitude of the speaker had $a$ significant bearing on the reaction of students. He argued that a "Christocentric, positive and instructive approach would win, where a negative, legal approach would fail." He stressed the need to translate theology into the language of students, and to address their developmental 
concerns and their felt needs. He believed that while the Holy spirit ministered to young people, "His work is either helped or delayed by what is said and the way it is said." Bower (1985, p. 38) also commented that teachers by their attitudes and body language had the capacity to either reinforce or negate the impact of the messages. He emphasized the need for teachers to foster and encourage feedback in the classroom, even at the expense of delaying regular classes and the need to structure class material to reflect the thematic or spiritual thrust of the week. Third, Bower (1985, p. 22) also suggested the importance of student involvement. He commented that while only a few students would play a leading part in the program, there was a place for every class member to participate. He argued that involvement often fostered commitment to the goals of the program and suggested that involvement made a student more receptive to the Holy Spirit.

Fourth, Gaebelein (1968, p. 98) emphasized the importance of the personal counselling sessions in fostering decisions and nurturing spiritual growth. He argued that

The most efrective results are often the quiet. face-to-face talks that occur when students, having being touched by the truth in christ, voluntarily come for individual counsel.

Finally, according to Hartman (1952, p. 29) and Maxwell (1952, p. 30), a very important way of fostering 
97

decisions and nurturing spiritual growth was through the follow-up process of establishing student/faculty prayer and study groups. According to Maxwel1 (1952, p. 30), such groups should not be over-organized but rather should form spontaneously and be made up of those who really wanted to stüyy of their own free will. He also suggested that the success of these groups was dependent on committed leaders who had a loving spirit. While Rebok (1947, p. 19) suggested that the group leaders should be chosen by group members, Hartman (1952, p. 30), by contrast, believed that the Week of Prayer committee should select the leaders ahead of time and only choose those who have "a vision of the possibilities of the Week of Prayer."

In summary, Weeks of Prayer/Spiritual Emphasis refer to the special occasions made available in the school curriculum for the purpose of fostering spiritual growth. The philosophy behind them was the need to meet two equally important challenges: to lead the non-committed to a commitment (the evangelistic function) and to nurture and strengthen those already committed (the nurturing function). A number of ways by which these challenges could be met were: prayer and preparation, speaker and teacher attitudes, student involvement: personal counselling sessions, and follow-up student/faculty prayer and study groups. 


\title{
Bible Classes
}

\author{
Bible classes should be the time in the school \\ program given to the study of scripture for the purpose of \\ enhancing student spiritual growth. The classes should be \\ designed to guide students in their relationship with \\ Christ in their quest for truth, in their understanding of \\ life, in the practics of christian living, and in the \\ cultivation of Christian values. \\ According to the literature, the study of scripture \\ was fundamental to spirituality. White (1923, p. 542) \\ underscored the importance of the Blble class when she \\ stated that the study of scripture should have "first place \\ in every system of education." She argued that "as an \\ educating power, it was of more value than the writings of \\ all the philosophers of all ages." According to Holmes \\ (1975, p. 26), "the teaching authority of scripture" arose \\ out of this "interpretive framework" which provided "an \\ overall glimpse of how everything relates to God." Byrne \\ (1977, pp. 72-73) added that it provided the student with a \\ contextual framework for the integration and interpretation \\ of the whole curriculum. \\ While the above positions represent and reflect the \\ general importance of biblical studies, there appeared to \\ be variation in what the chief emphasis of Bible classes \\ should be. According to Bartholomew (1927, p. 23), the \\ chief emphasis should be one of teaching "the saving truths \\ of evangelical Christianity" and building up in the minds
}


of students "a coherent, systematic body of knowledge about the facts and doctrine of the Holy Scriptures." Ott (1978, p. 21-22), by contrast, emphasized the philosophical rather than doctrinal aspects. He argued that the central focus should be one of providing students with a Christian world view, self-understanding, and guidance in the development of a Christian value system. In contrast with both of these views, Hay (1983, p. 142) emphasized the need to focus on the experiential aspects of Christianity. He argued that the aim of teaching religion was twofold: to enhance personal awareness of those aspects of individual experience through which God spoke and to present religion as a response of human beings to what they experienced as the sacred. He believed that religious experience should be one that responded to the divine initiative through personal experiential faith. Doctrinal faith, he believed, was subsidiary to this goal. However, despite the differences in opinion, it was clear from these same sources that the overriding goal was still the need to guide students into a personal relationship with Jesus. From a nurturing perspective, the doctrinal, philosophical. and the experiential aspects of Christianity need to be couched against this overriding goal.

The literature identified a number of ways Bible classes could nurture spiritual growth. One was by meeting the intellectual and experiential needs of each student. Given this orientation, the views of Bartholomew, Betts, 
.00

Ott, and Hay, summarized above, supported this point. But in considering the spiritual growth of the "whole person." there needs to be a balance between the knowledge and the experiential aspects of spirituality. According to Gallagher (1982, p. 39), the emotional and intellectual sensitivity of young people to spiritual matters was the very opportunity and challenge needed in the Bible class. He stated that there was "immeasurable spiritual potential to be derived from this sensitivity."

A second way Bible classes could nurture spiritual growth is by demonstrating in class the practice and methods of Bible study and prayer. In view of the importance of both to spiritual growth, the Bible class was an appropriate place for students to witness the correct usage and methods of Bible study and to be guided in their understanding and the practice of prayer (Reck, 1979, p. 47). According to White (1952, p. 190), students should "be taught to give close study to the word of God" with the implication that they should be taught how to study the Bible and to how to discover its meaning for their lives. Stanley (1985) also suggested that students needed to understand more fully the nature of prayer - how they might hear the volce of God speaking to them in the context of their lives and how they might "constantly" communicate with the Lord.

A third way Bible classes could nurture spiritual growth is by addressing issues which had immediate 
relevance to the adolescent. Dudley (1984, p. 4)

underscored the importance of Bible relevancy. He argued that many young people came to view scripture as "only remotely connected to their own experience." One reason Judd (1986, pp. 45-46) gave in accounting for the alienation of Adventist youth from religion was the refusal of the church to address "the real issues they face." He suggested there was a need in the religion class to "face every issue openly and honestly making sure that the topics discussed actually connected with the lives of the youth." Similarly, Shelton (1983, p. 5) stressed the need for Scripture to be presented in a way which addressed such adolescent concerns as self-esteem and identity, sexual roles and identity, relating to parents and achieving independence, relating to peers, educational experiences, establishing personal values and a philosophy of life, becoming a sexual person, and choosing and preparing for an occupation (Lloyd, 1985).

A final way of nurturing student spirituality in the religion class was by facilitating an environment of open sharing. Hay (1983, p. 144) commented that there was a need for "providing an environment in which there was permissiveness with regard to religion." He explained:

I mean. . . the positive creation of a climate in which the class members give themselves and others permission for the unhindered examination of the religious areas of human experience. 
102

From a slightly different perspective, Nouwen (1975, p. 62) emphasized the need for an open environment of interchange for the purpose of offering to students a place

where they can reveal their great human potentials to love, to give, and to create, and where they can find the affirmation that gives them the courage to continue their search without fear.

In summary, Bible classes should be the times in the school program given to the study of scripture for the purpose of enhancing student spiritual growth. According to the literature. Bible study was of fundamental importance because of its intrinsic value for spiritial growth and because it provided a contextual framework for the integration and interpretation of how everything related to God. Theorists differed in their views of the chief emphasis of biblical studies. This suggested that the overriding goal of enhancing a student's relationship with Christ should be reflected in a more explicit orientation towards the spiritual nurture of each student. Accordingly, a number of ways Bible classes could nurture student spirituality included: meeting the intellectual and experiential needs of each student, demonstrating the practice and methods of Bible study and prayer, addressing issues that have immediate relevance to the adolescent, and facilitating an environment of open sharing.

\section{Summary}

This chapter presented a review of literature related to Christian spirituality and spiritual nurture in 
Christian education in order to $F=="$ ide a theoretical background for the study and a credible basis for developing the Spirituality Inventory (SI) and the Spiritual Nurture Inventory (SNI). In view of the scope of literature, the review sought only to be representative rather than exhaustive.

The purpose of part one of the review of literature was to discover from scripture and the literature of Christlan spiritual masters, basic principles and practices which undergird Christian spirituality. While this part of the review was only a tentative step into the difficult area of defining spirituality, it was an attempt to identify the dimensions generally accepted as fundamental to Christian spirituality. The 10 dimensions adopted in this study and which constituted the framework for section one of this chapter included: meditation, prayer, study, confession, submissicn, solitude, service, worship, guidance, and joyfulness.

The purpose of part two of the review of literature was to identify the dimensions of Christian education considered fundamental to nurturing student spirituality and to discover the basic principles and practices within those dimensions which fostered student spiritual growth. Reflecting the collective thought of many educational theorists and practitioners cited throughout the review, the construct which was finally adopted for this study included the following dimensions: principal spirituality, 
school curriculum, teaching methodologies, school

discipline, teacher spirituality, worship experiences,

community outreach, Bible teacher spirituality, weeks of spiritual emphasis, and Bible classes. 
CHAPTER III

\title{
METHODOLOGY
}

\begin{abstract}
This chapter presents a description of the merhodology employed in the study. It describes the population and sample, instrumentation, instrument development procedures, data collection procedures, and the statistical analyses adopted.

\section{Population and Sample}

Seventh-day Adventist day academies in the United States constituted the population for the study. Twenty day academies, with student enrollments above 50, weIk randomly selected from the 40 day academies in the United states. While the enrollment limitation was adopted to ensure sufficient numbers of seniors from each academy. each of the eight union conferences in the United States were represented. Of the 20 day academies and 753 seniors selected, is academies with responses from 591 seniors returned the SI and the SNI for analysis. Boarding academies were excluded from the population to minimize variables which may be peculiar to them.
\end{abstract}




\section{Instrumentation}

Two Iikert attitude scales were developed for the study. First, the Spirituality Inventory (SI) was designed to measure the implied levels of student spirituality evident in a school. The SI indicated one of three levels of spirituality: high, moderate, or low.

second, the Spiritual Nurture Inventory (SNI) was designed to measure the level of spiritual nurture in each of the selected educational dimensions identified in the literature as being fundamental to student spiritual growth. The SNI indicated one of three levels of spiritual nurture for each educational dimension: high, moderate, or low.

\section{Instrument Development Procedures}

The first procedure was to identify from the literature the basic construct upon which each scale was to be developed. The SI construct adopted initially is presented in Table 1 although dimensions 11 and 12 were subsequently omitted from the final SI scale.

The SNI construct adopted initially is presented in Table 2 although dimensions 12 and 13 were subsequently omitted from the final SNI scale. In acknowledgment of the importance of the home, an additional dimension, "Home Environmental Influence," was added to the SNI.

The second procedure was to develop items which adequately reflect each dimension of the scale. Six items 
TABLE 1

SI CONSTRUCT

1. Meditation

2. Prayer

3. Study

4. Confession

5. Solitude

6. Submission

7. Service

8. Worship

9. Guidance

10. Joyfulness

*11. Fasting

*12. Simplicity

* Dimensions omitted in final SI scale

TABLE 2

SNI CONSTRUCT

1. Princlpal Spirituality

2. School Curriculum

3. Teaching Methodology

4. School Discipline

5. Teacher Spirituality

6. School Worships

7. Community Service

8. Bible Teacher

9. Weeks of Prayer

10. Bible Classes

11. Home Environmental Influence

*12. Spiritual Retreats

*13. School Facilities

* Dimensions omitted in final SNI Scale 
were written for each dimension. For reliability purposes, a balance of positive and negative items were written initially for each dimension. (A later analysis indicated that the means of the positive and negative items used in the study were approximately equal).

Content validlty was established by two panels of five judges. The five judges for the $S I$ included a ministerial director, three theologians, and a church pastor. The five judges for the SNI included an educational director, two school administrators, a university education professor, and an academy teacher. Content validity of the SNI was also verified by a correlational analysis of SNI items with student spirituality scores. The analysis revealed that 52 of the 60 SNI items had significant correlations with student spirituality at the .01 level. However, five of the six items in the Communicy Service Outreach dimension were not significantly correlated at the .01 level.

Statistical reliability for each scale was established by collecting data in three pilot studies and conducting an item analysis of the results. Reliability was also established through post-descriptive item and factor analysis using the study data. The SI scale was analyzed for overall reliability with the assumption that the dimensions identified in the literature were 12 content areas of one construct, namely, spirituality. The SNI, on 
the other hand, was analyzed in terms of the reliability of each educational dimension of spiritual nurture.

The first pilot study, with a sample population of 49 seniors, was conducted at Andrews Academy. The SI consisted of 12 dimensions and 72 items with an overall reliability coefficient of .9263 . However, by eliminating the dimension of "Fasting" and six other items with point multi-serials below . 2000, the overall reliability coefficient rose to .9380 . It was dectded that because of the unreliability of the dimension of "Fasting" and the virtual rejection of that practice among Adventist young people, it should be eliminated from the study. Of the six items with low point multi-serlals, three were rewritten and three were replaced. The changes were subsequently tested for reliability in a second pilot study. The SNI consisting of 13 dimensions and 78 items had seven dimensions with reliability coefficients above .6000. By eliminating seven items, the reliability coefficients of three more dimensions rose above .6000 . Dimensions 9,11 , and 12 continued to have low reliability coefficients. It was deflded that the seven items should be rewritten and an attempt made to improve dimensions 9 , 11. and 12. The changes were tested for reliability in a second pilot study.

This second pilot study, with a sample population of 62 juniors and seniors, was conducted at wisconsin Academy. The SI consisted of 11 dimensions and 66 items 
110

with an overall reliability coefficient of .9401. However, while the overall reliability improved and the point multiserials improved for most items, some items continued to remain low. The dimension of "simplicity" again had three items with point multi-serlals below .2000. Consequently, it was decided to test again the reliability of the SI in a third pilot study omitting the dimension of simplicity. rewriting six items and replacing two other items.

The SNI consisting of 13 dimensions and 78 items had six dimensions with reliability coefficients above .7000. The reliability of all dimensions improved significantly with the exception of "School Facilities" which had a reliability coefficient of only .3295. While the point multi-serials for most items improved, there were two items with point multi-serials below .3000.

It was also discovered that spiritual retreats were not attended by all students. Furthermore, it was suggested that there was a distinct likelihood that some schools may not include them as a regular feature of the school curriculum. Therefore, 10 of the 20 academies were contacted and it was learned that only $40 \%$ incorporated such retreats in their curriculum. While it was recognized that such activities would undoubtedly contribute to student spiritual growth, it was thought that because it was not common to all schools and all students, it should be eliminated from the study. Consequently, it was decided to again test the reliability of the SNI in a third pilot 
$1: 1$

study omitting the dimensions of "School Facilities" and "Spiritual Retreats," replacing the two weak items and making small adjustments to six other items.

The third pilot study, with a sample population of 71 juniors, was conducted at Andrews Academy. The SI consisting of 10 dimensions and 60 items had an overall reliability coefficient of .9410 . It was discovered that the rellability coefficlent of the SI with 50 items was .9425 , with 401 irems .9435 , and with 30 items .9421 . It was decided for statistical and content validity purposes that the SI consist of 10 dimensions (See Table 1) with four items in each, a total of 40 items for the scale (see Appendix 1). All 40 items had point multi-serials ranging from .3321 to .7394 .

The SNI consisting of 11 dimensions and 66 items had six dimensions with reliability coefficients above .7000. However, the reliability of all dimensions rose further when six items were omitted from the study. Table 3 presents the reliability coefficients for each of the dimensions after eliminating the six items. It was decided for statistical and content validity purposes that the SNI consist of 11 dimensions (See Table 2) with five items in six dimensions and six items in five dimensions, a total of 60 items for the scale (See Appendix 1).

A third procedure was an item weight analysis on the data collected from the 19 academies. While this was a post descriptive analysis of the instruments, it provided 
TABLE 3

SNI RELIABILITY COEFEICIENTS

\begin{tabular}{llc}
\hline SNI Dimensions & $\begin{array}{c}\text { Reliability } \\
\text { Coefficients }\end{array}$ \\
\hline 1 Principal Spirituality & .7192 \\
2 School Curriculum & .6287 \\
3 Teaching Methodology & .6200 \\
4 School Discipline & .7290 \\
5 Teacher Spirituality & .6401 \\
6 School Worships & .6279 \\
7 Community Service & .8102 \\
8 Bible Teacher & .7360 \\
9 Weeks of Prayer & .8001 \\
10 & .7502 \\
11 & Home Environmental Influence \\
\hline
\end{tabular}

Reproduced with permission of the copyright owner. Further reproduction prohibited without permission. 
13

confirmation, with larger numbers of subjects, of the reliability of the respective instruments. The results for the SI are shown in Table 4 and for the SNI in Table 5. The reliability coefficients are listed for each instrument and for each scale together with the point multi-serials for each item. A complete list of scale dimensions and items together with the results are found in Appendix 1. The SI, consisting of 10 dimensions and 40 items. had an instrument reliability coefficient of .9343, scale reliability coefficients ranging from .4699 to .8275 , and item-point multi-serials ranging from .5477 to .8390 (See Table 4).

The SNI consisting of 11 dinensions and 60 items had an instrument reliability coefficient of .9222 , scale reliability coefficients ranging from .5875 to .8055, and item-point multi-serials ranging from .4129 to .8230 (See Table 5).

The fourth procedure was a post-descriptive factor analysis and stepwise multiple-regression test of the SI on the data collected from the nineteen academies. According to the SI factor analysis, the eigenvalue for factor number one was 12.6598 but fell to 2.3430 on a second factor (See Table 6$)$. This result confirmed earlier expectations and confirmed the SI must be viewed as a one factor instrument.

The SI stepwise multiple-regression results suggested that $72.54 \%$ (See RSQ, Table 7) of spirituality can be predicted using only one scale (SI 9 Guidance) of 
TABLE 4

SI ITEM WEIGHT ANALYSIS

\begin{tabular}{|c|c|c|c|c|c|}
\hline $\begin{array}{c}\text { SI } \\
\text { Dimension }\end{array}$ & $\begin{array}{c}\text { Scale } \\
\text { Reliability } \\
\text { Coefficient }\end{array}$ & 1 & $\begin{array}{r}\text { int } \\
2\end{array}$ & i-serial & 4 \\
\hline $\begin{array}{r}1 \\
2 \\
3 \\
4 \\
5 \\
6 \\
7 \\
8 \\
9 \\
10\end{array}$ & $\begin{array}{l}.6672 \\
.7194 \\
.7504 \\
.5250 \\
.7037 \\
.4757 \\
.4699 \\
.8275 \\
.7260 \\
.7611\end{array}$ & $\begin{array}{l}.7130 \\
.7729 \\
.7544 \\
.6880 \\
.7679 \\
.6604 \\
.6533 \\
.7909 \\
.7541 \\
.8094\end{array}$ & $\begin{array}{l}.7435 \\
.7533 \\
.7388 \\
.5650 \\
.7462 \\
.5978 \\
.6351 \\
.8390 \\
.7752 \\
.7046\end{array}$ & $\begin{array}{l}.6558 \\
.6071 \\
.7587 \\
.6956 \\
.7173 \\
.5477 \\
.6300 \\
.7908 \\
.6932 \\
.8111\end{array}$ & $\begin{array}{l}.7276 \\
.8054 \\
.7790 \\
.6562 \\
.6815 \\
.6901 \\
.5887 \\
.8383 \\
.7416 \\
.7737\end{array}$ \\
\hline
\end{tabular}

SI Reliability Coefficient .9343

TABLE 5

SNI ITEM WEIGHT ANALYSIS RESULTS

\begin{tabular}{cccccccc}
\hline $\begin{array}{c}\text { SNI } \\
\text { Dimension }\end{array}$ & $\begin{array}{c}\text { Scale } \\
\text { Reliability } \\
\text { Coefficient }\end{array}$ & 1 & \multicolumn{6}{c}{$\begin{array}{c}\text { Item } \\
\text { Point } \\
\text { Multi-Serial }\end{array}$} & \\
\hline & & & 3 & 4 & 5 & 6 \\
1 & .7743 & .7188 & .8128 & .6958 & .7698 & .6418 & \\
2 & .5875 & .5550 & .6687 & .5020 & .5375 & .6336 & .5313 \\
3 & .6063 & .5879 & .5145 & .6200 & .6164 & .4692 & .6780 \\
4 & .7469 & .6802 & .7033 & .5209 & .7040 & .7275 & .6586 \\
5 & .6772 & .6748 & .6030 & .4129 & .6862 & .6938 & .6210 \\
6 & .6048 & .6059 & .6362 & .5160 & .6722 & .6900 & \\
7 & .7631 & .7497 & .7418 & .6874 & .6638 & .7437 & \\
8 & .8002 & .8016 & .7636 & .6742 & .7702 & .7288 & \\
9 & .7951 & .5086 & .8230 & .7614 & .8203 & .7859 & \\
10 & .8055 & .7490 & .7807 & .7962 & .6887 & .7330 & \\
11 & .7861 & .5715 & .7594 & .7306 & .7431 & .7100 & .6720 \\
\hline
\end{tabular}

SNI Reliability Coefficient .9222 
TABLE 6

SI FACTOR ANALYSIS RESULTS

\begin{tabular}{ccc}
\hline Factor & $\begin{array}{c}\text { Variance } \\
\text { Explained } \\
\text { (Eigenvalue) }\end{array}$ & $\begin{array}{c}\text { Cumulative Prop } \\
\text { of Variance } \\
\text { Explained }\end{array}$ \\
\hline 1 & 12.6598 & 0.5588 \\
2 & 2.3430 & 0.6622 \\
3 & 1.5934 & 0.7325 \\
4 & 1.3983 & 0.7942 \\
5 & 1.3486 & 0.8537 \\
6 & 1.2310 & 0.9081 \\
7 & 1.0799 & 0.9557 \\
8 & 1.0028 & 1.0000 \\
\hline
\end{tabular}

TABLE 7

SI STEPWISE REGRESSION SUMMARY TABLE

\begin{tabular}{rcrrr}
\hline Step No & $\begin{array}{l}\text { Variable } \\
\text { Entered }\end{array}$ & RSQ & $\begin{array}{c}\text { Change in } \\
\text { RSQ }\end{array}$ & $F$ to Enter \\
\hline 1 & SI 9 & 0.7254 & 0.7254 & 1487.03 \\
2 & SI 10 & 0.8449 & 0.1196 & 433.40 \\
3 & SI 2 & 0.8939 & 0.0489 & 258.51 \\
4 & SI 6 & 0.9242 & 0.0303 & 223.88 \\
5 & SI 8 & 0.9503 & 0.0261 & 293.45 \\
6 & SI 3 & 0.9659 & 0.0156 & 255.29 \\
7 & SI 5 & 0.9793 & 0.0134 & 360.61 \\
8 & SI 4 & 0.9878 & 0.0085 & 385.76 \\
9 & SI 7 & 0.9946 & 0.0069 & 710.06 \\
10 & SI 1 & 1.0000 & 0.0054 & - \\
\hline
\end{tabular}

RSQ $(r)$ = Variance Explained 
the SI. With three scales (SI 9 Guidance, SI10 Joyfulness, SI 2 Prayerl, the variance explained increased to $89.39 \%$ and for four scales (SI 9 Guidance, SI 10 Joyfulness, SI 2 Prayer, SI 6 Submission), it increased to $92.42 \%$.

The SI stepwise multiple-regression results also suggested that spirituality may be predicted using any one of eight combinations of three SI dimensions with RSQ ranging from 0.8690 to 0.8939 (See Table 8 ). While it is advisable to use the 10 dimensions of the SI for major research, it appears that any one combination of three dimensions shown in Table 8 would be an efficient way of predicting spirituality.

\section{Data Collection Procedure}

The 20 academies were first contacted by a letter outlining the nature and goals of the research and requesting their participation in the study (see Appendix 2). The principals were subsequently called by telephone to confirm a timetable of data collection. All 20 academies agreed to participate in the research. Questionnafres (See Appendix 3), together with the Human Subjects Approval Form, Informed Consent Forms (See Appendix 4), and a covering letter (See Appendix 2) were packaged and forwarded to each academy. 19 academies returned the completed questionnaires. 
TABLE 8

A THREE DIMENSION SI

\begin{tabular}{lll}
\hline No & RSQ & Variable Combinations \\
\hline & 0.8939 & $2,9,10$ \\
1 & 0.8920 & $5,9,10$ \\
3 & 0.8840 & $3,9,10$ \\
4 & 0.8810 & $2,3,18$ \\
5 & 0.8810 & $4,9,10$ \\
6 & 0.8780 & $6,9,10$ \\
7 & 0.8780 & $8,9,10$ \\
8 & 0.8690 & $7,9,10$ \\
\hline
\end{tabular}




\title{
Statistical Analyses
}

Two statistical procedures were employed in the study to analyze the data and test the three hypotheses. Analysis of variance (ANOVA) was used to test the first two hypotheses for variance that may exist between and within variables. This statistical procedure was employed, first, to test whether there were differences in the levels of school spirltuality and, second, to test whether there were differences in the levels of spiritual nurture in the educational dimensions studied among the 20 day academies selected.

Multiple-regression (MR) was used to test the third hypothesis. This method was used to analyze the relationship between the implied levels of student spirituality (DV) and the levels of spiritual nurture found within the educational dimensions studied (IV).

\begin{abstract}
Summary
Seventh-day Adventist day academies in the United States were the population for the study with a random sample of 20 schools. Two Iikert attitude scales, the Spirituality Inventory (SI) and the Spiritual Nurture Inventory (SNI), were developed for the study. Content validity for each instrument was established by two panels of five judges while statistical reliability was established by a series of three pilot studies, and postdescriptive item and factor analysis of the study data. of
\end{abstract}




$$
\because 9
$$

the 20 day academies and 753 seniors selected, 19 day academies with responses from 591 seniors returned the SI and the SNI for analysis. The statistical analyses employed to analyze the data and test the three hypotheses included analysis of variance and multiple regression. The results of the study are presented in Chapter IV. 
CHAPTER IV

RESULTS

This chapter presents an analysis of the data collected in this study. The findings are presented in three sections. In an examination of Hypotheses 1 and 2. the first section analyzes the data concerning possible differences in the levels of spirituality and of spiritual nurture between Seventh-day Adventist day academies in the United states. In an examination of Hypothesis 3 , the second section analyzes the data concerning the possible reiationsing between the dimensions of spiritual nurture and spirituality in Seventh-day Adventist day academies in the United States. The third section summarizes the findings of the study and discusses their implications for educational administrators.

\section{Differences in the Levels of Spirituality and in the Levels of Spiritual Nurture in Seventh-day Adventist Day Academies in the United States}

Table 9 presents the SI and SNI means in rank order from highest to lowest. This table is designed to highlight the differences in the levels of spirituality and spiritual nurture between schools. While differences 
TABLE 9

TABLE OF SI ANO SHI MEANS BY RAMK ORDER

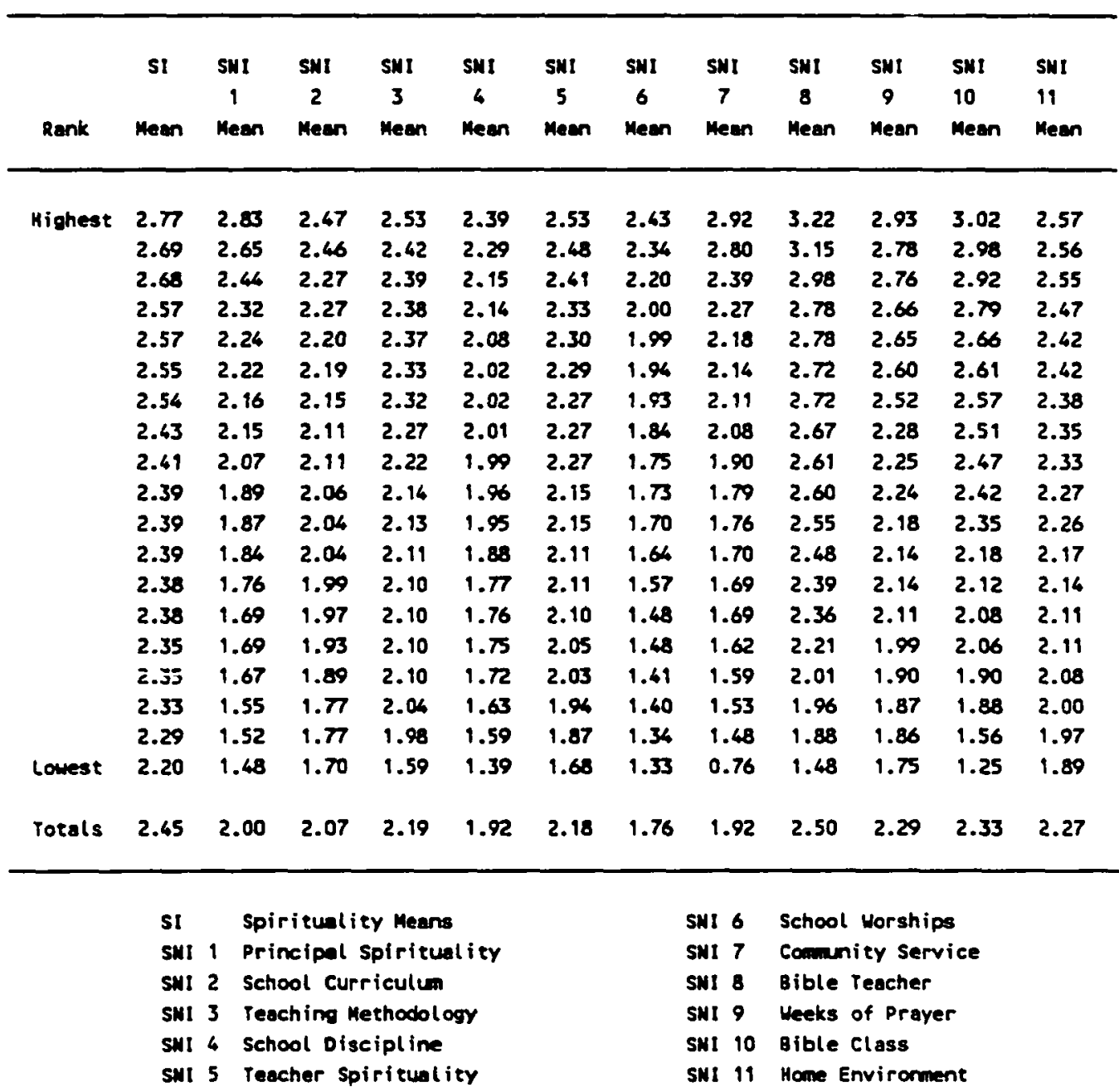

Reproduced with permission of the copyright owner. Further reproduction prohibited without permission. 
in spifituality between schools ranged from 2.77 to 2.20 with a combined mean score of 2.45 , differences in the levels of spiritual nurture ranged from 3.22 (Bible Teacher) to 0.76 (Community service) with a combined means ranging between 2.50 (Bible Teacher Spirituality) and 1.76 (School Worships). While there were wider differences in Community Service, Bible Teacher, Bible Class, and Principal spirituality, there were comparatively small differences in School Curriculum, Teaching Methodology, School Discipline, and Tsachcr spizituality. The widest difference was Community Service Outreach $(2.92-0.76)$ and the smallest difference was Home Environmental Influence $(1.89-2.57)$. There were similarities in both range and means in School Curriculum, Teaching Methodology, and Teacher spirituality. While there were wider but similar differences in Bible Teacher spirituality $(2.50)$ and Bible Classes (2.33), they, together with Weeks of Prayer $(2.29)$, had the highest means with Bible Teacher spirituality highest of all.

The results confirmed the expectation that there were differences in the levels of spirituality between Seventh-day Adventist day academies in the United States. However, as the small range of means suggested, differences in spirituality "between schools" were small with significant differences found between only three schools. This finding suggests that there is similarity in levels of spirituality "between schools" and that divergent levels of 
spirituality were moderate. Notwithstanding, the results sill provided a basis for identifying significant relationships between dimensions of spiritual nurture and hlgher levels of student spirituality.

The combined (total) means of the SNI dimensions presented in Table 9 , suggest that highest levels of spiritual nurture were achieved in the areas of Bible Teacher Spirituality, Bible Classes, and Weeks of Prayer. while the lowest levels of spiritual nurture were achieved in the areas of school Worships and Community Service. The results also suggest that the perceptions of spiritual nurture "between schools" varied greatly in the areas of Community service, Bible Class, and Bible Teacher, but varied least in the areas of school Curriculum, Teaching Methodology, School Discipline, Teacher Spirituality, and Home Environment. The dimension with greatest variation was Community Service, while the dimension with least variation was the Home Environment. This latter finding suggested that there were small differences in levels of student spirituality between urban and rural homes. Table 10 is designed to complement rable 9 . It presents a series of boxplots in order to facilitate visual comparisons and to illustrate the differences in the SNI dimensions highlighted in Table 9 and in the above discussion. Each boxplot shows the highest and lowest scores, the 1st and 3rd quartiles, and the median score for each spiritual nurture dimension. 
TABLE 10

BOXPLOTS OF SHI MEANS

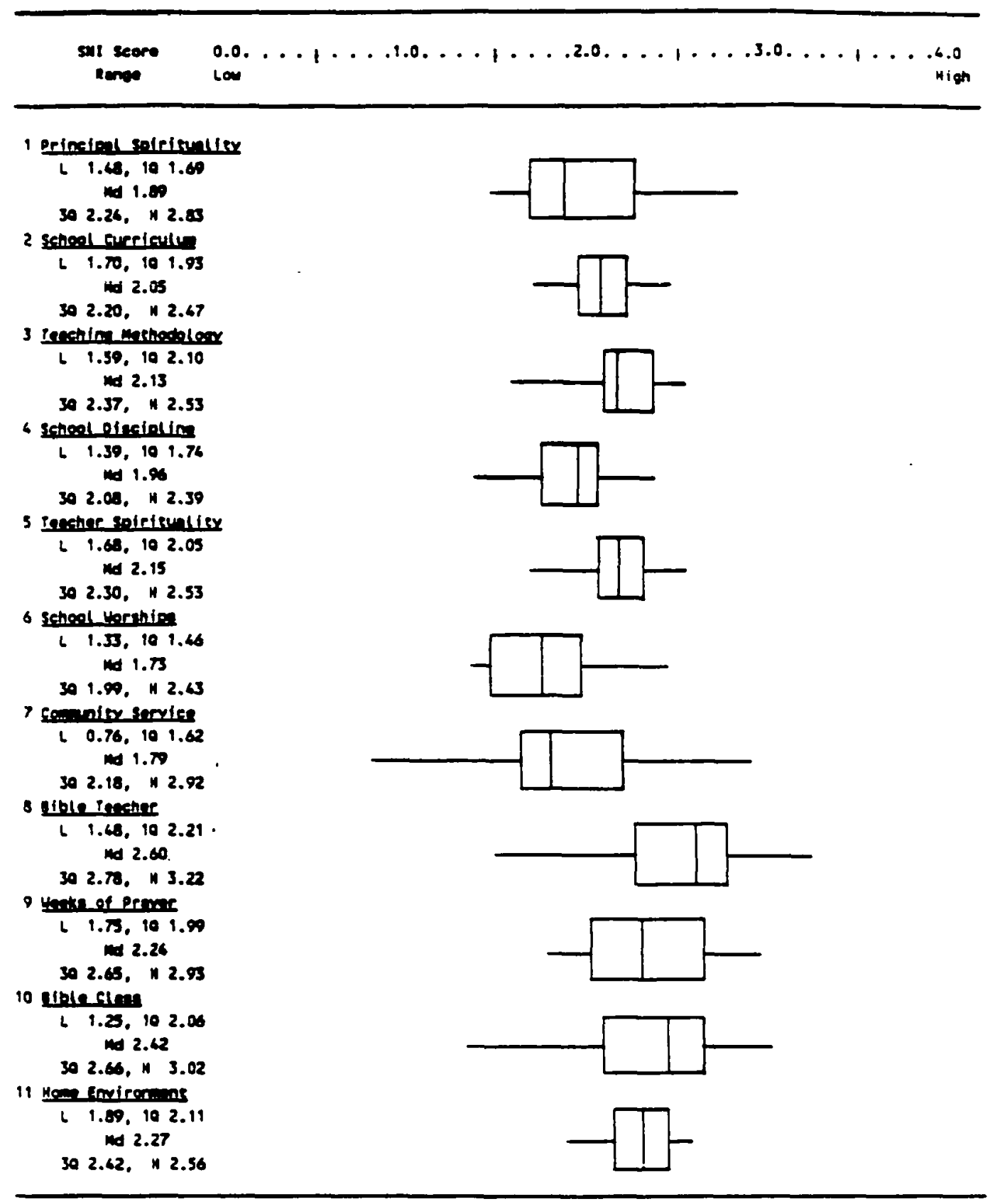

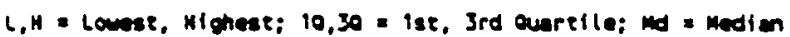

Reproduced with permission of the copyright owner. Further reproduction prohibited without permission. 
Table 11 presents a table of the SI and SNI means and ranks by school order together with school SNI rank means. This table is designed to highlight, first, the differences in the levels of spiritual nurture "within schools" and, second, the differences between the levels of spirituality and spiritual nurture "within schools." First, differences in the levels of spiritual nurture "within schools" were found by comparing the rango of SNI ranks. The smallest range of spiritual nurture was found within School 12 with 10 SNI dimensions ranging between ranks 1 and 6.5 and within school 3 with 10 SNI dimensions ranging between ranks 16 and 19 . The widest range occurred within school 1 with ranks ranging between 1 (Community Service) and 19 (Bible Class) and School 2 with ranks ranging between 3 (Kome Environmental Influence) and 18 (School Worships). Other differences included: School 13 which had six SNI dimensions ranging between ranks 1 and 3 and three SNI dimensions with ranks of 13 or 13.5 ; and School 14 which had four SNI dimensions ranging between ranks 1 and 2 and four SNI dimensions ranging between ranks 13 and 19 .

The results suggest that the SNI dimensions of spiritual nurture $\#=z=$ rated ennsistently high in School 12. consistently low in school 3 , but were inconsistertly rated in schools 1 and 2 . Overall, the results suggested that spirituel nurture "within schools" yaried considerably. It was rated consistently high in three 


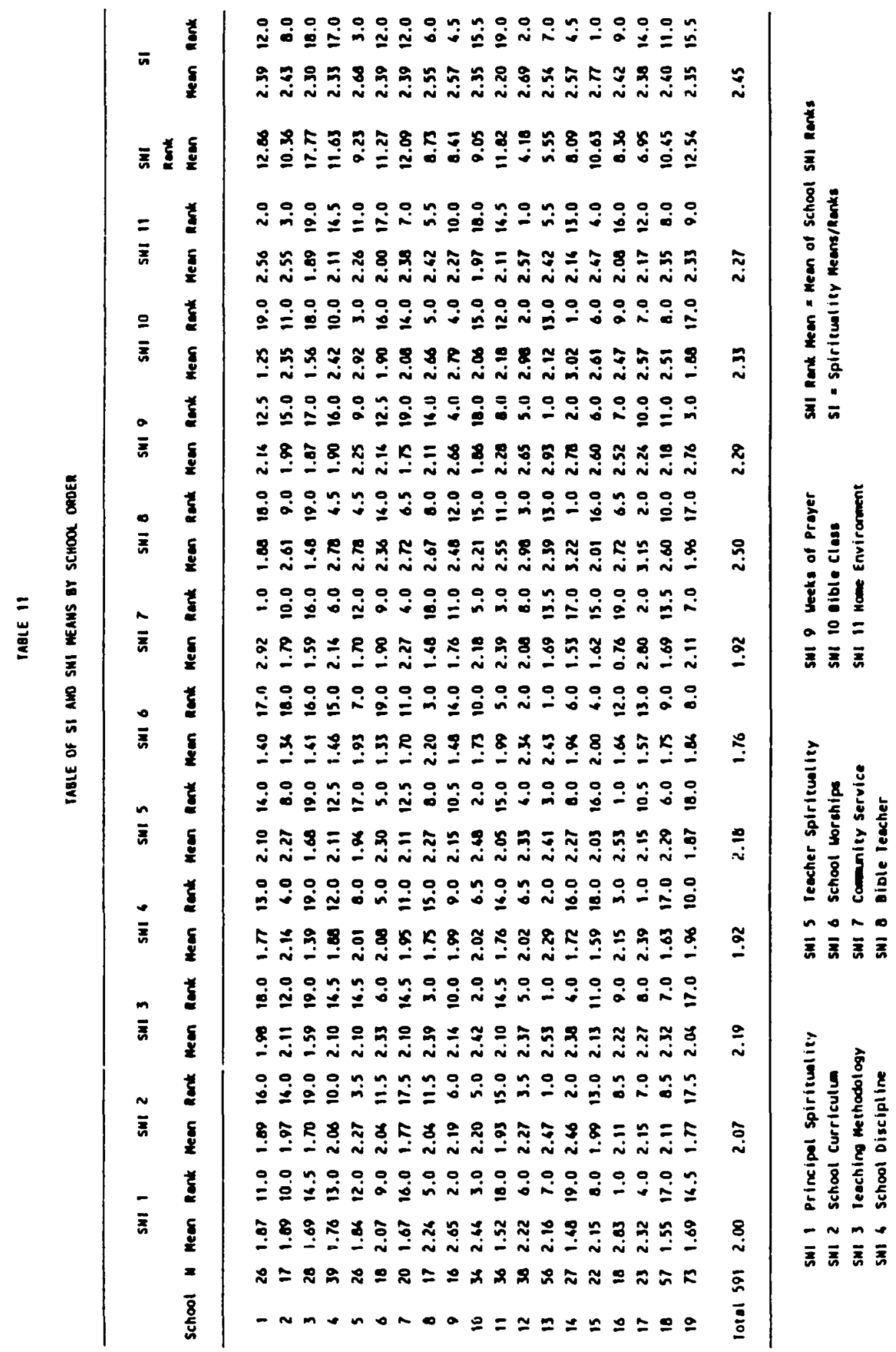


schools, consistently low in seven schools, and inconsistently rated in nine schools.

Second, differences between the levels of spirituality and spiritual nurture "within schools" were found by comparing the school SI rank with the mean of the school SNI ranks (SNI rank mean). Schools with largest differences included School 15 which had the highest SI rank (1) and an average SNI rank mean (10.63), while School 17 by contrast had a below average SI rank (14) and a comparatively high SNI rank mean (6.95). Schools with smallest differences included school 12 which had the second highest SI rank (2) and the highest SNI rank mean (4.18), while School 3 had the second lowest SI rank (18) and the lowest SNI rank mean (17.77).

The results suggest that school 12 had the highest combination of spirituality and spiritual nurture ratings across the sample, while school 3 had the lowest combination of spirituality and spiritual nurture ratings across the sample. Overall, it was found that when comparing both areas of spirituality and spiritual nurture ratings "within schools," three schools had high ratings, eight schools had moderate ratings, five schools had low ratings, and six schools were inconsistently rated.

Relationships between Spirituality and Spiritual Nurture in Christian Education

In seeking to identify the relationships between spirituality and spiritual nurture in Christian education. 
two approaches were adopted, the analysis of both student spirftuality and school spirituality. Both analyses were included because it was assumed that spirituality is likely to be confounded by extraneous varlables outside the school such as the influence of spiritual nurture within the home. On the other hand, while school spirituality (mean of all students) would minimize the fnfluence of extraneous variables, it would not fully reveal the impact of spiritual nurture on fndividual students.

In addition this question presented itself, Is student spirituality a function of student perceptions of spiritual nurture or is it a function of the overall school ("real") level of spiritual nurture or both? While it may be argued that the "real" levels of spiritual nurture within a school are critical to genuine spiritual growth among students, It may also be argued that spiritual nurture is a function of numerous personal variables that may or may not be influenced by a high level of spiritual nurture in a school at which a student attends. Consequently, the analysis distinguishes between student perceptions and the overall school ("real") level of spiritual nurture.

Accordingly, this section of the results of the analyses is divided into three parts. The first part presents the results of the relationship between student spirituality (student SI scores) and student perceptions of spiritual nurture within schools (student SNI scores). The 
second part presents the results of the relationship between student spirituality (student SI scoresi and sciooi spiritual nurture (school SNI means). The thiri part presents the results of the relationship between school spirituality (school SI means) and school spiritual nurture (school SNI means). The three parts are presented in analysis of Hypothesis 3 .

\section{Relationship between student spirituality \\ (SI Scores) and student Perceptions of Spiritual Nurture (SNI Scores)}

Table 12 presents the simple (zero-order) correlations between student SI scores and student SNI scores. Significant differences at the .05 level were those with an F ratio larger than 3.858. All SNI dimensions were significantly correlated with student spirituality with correlations ranging between .1000 and .5098. Although significant, the percentage of variance of student spirituality explained by each SNI dimension ranged from a low $1 \%$ to a high 26\%. Those which explained high levels of variance included: Weeks of Prayer (SNI 9) 26\%: School Worships (SNI 6) 18.6\%: Bible Classes (SNI 10) 19.2\%; and Home Environmental Influence (SNI 11) $11.2 \%$ (See Table 12). The correlation matrix also revealed four high correlations between SNI dimensions: Teaching Methodology and Teacher Spirituality .686z; School Curriculum and Teaching Methodology .6231: School Curriculum and Teacher 
TABLE 12

CORRELATION BETWEEN STUDENT SI SCORES

AND STUDENT SNI SCORES

\begin{tabular}{ccc}
\hline $\begin{array}{c}\text { SNI } \\
\text { Dimension }\end{array}$ & Correlation & $\begin{array}{c}\text { Variance } \\
\text { Explained }\end{array}$ \\
\hline 1 & $.2388^{*}$ & $5.7 \%$ \\
2 & $.2394^{*}$ & $5.7 \%$ \\
3 & $.236^{*}$ & $5.4 \%$ \\
4 & $.220^{*}$ & $5.1 \%$ \\
5 & $.2672^{*}$ & $7.1 \%$ \\
6 & $.4313^{*}$ & $18.6 \%$ \\
7 & $.1000^{*}$ & $1.0 \%$ \\
8 & $.3148^{*}$ & $9.9 \%$ \\
9 & $.5098^{*}$ & $25 \%$ \\
10 & $.4390^{*}$ & $19.2 \%$ \\
11 & $.3348^{*}$ & $11.2 \%$ \\
\hline
\end{tabular}

* Denotes significance at the .05 level Variance Explained $=r^{2} \times 100$ 
Spirituality .6335; and Bible Teacher Spirituality and Bible Classes .6605.

The results suggest that while there were significant relationships between all the SNI dimensions and "student spirituality," the most strongly related were Weeks of Prayer, School Worships, Bible Classes, and the Home Environmental Influence.

High correlations involving school Curriculum, Teaching Methodology, and Teacher Spirituality confirm the interrelatedness of what is presented, how it is presented, the type of person who presents the material, and spiritual nurture. It underscores the difficulty of attempting to separate the three functions and the need for all to be equally strong.

Using student SNI and SI scores, both stepwise and backward-step regression were empioyed io ascertain which SNI dimensions were likely to best predict "student spirituality." Since both methods revealed ldentical results, only the stepwise-regression analysis is presented.

Table 13 presents a stepwise-regression model of five predictors (SNI 9, 10, 11, 6, 2) w1th a total variance explained of $38.58 \%$. The analyses added predictors in order of highest partial correlations with an $F$ ratio above 4.00 which approximates the .05 ievei. In this modei. SNI 9 (Weeks of Prayer) accounted for the initial $26.0 \%$ of the total variance of student spirituality, SNI 10 (Bible 
TABLE 13

STUDENT SPIRITUALITY STEPWISE SELECTION USING STUDENT SNI SCORES

\begin{tabular}{ccccc}
\hline $\begin{array}{c}\text { Step } \\
\text { No. }\end{array}$ & $\begin{array}{c}\text { Var. } \\
\text { Added }\end{array}$ & $\begin{array}{c}\text { Var in } \\
\text { Model }\end{array}$ & RSQ & $\begin{array}{c}\text { Change } \\
\text { in RSQ }\end{array}$ \\
\hline 1 & 9 & 9 & .2599 & .2599 \\
2 & 10 & 9,10 & .3269 & .0670 \\
3 & 11 & $.9,10,11$ & .3713 & .0444 \\
4 & 6 & $9,10,11,6$ & .3810 & .0097 \\
5 & 2 & $9,10,11,6,2$ & .3858 & .0048 \\
\hline
\end{tabular}

- Denotes model selected 
Class) an additional 6.7\%, and SNI 11 (Home Environmental Influence) an additional 4.4\%. While the dimens:ons SNI 6 (School Worships) and SNI 2 (School Curriculum) were also significant, the additional variance explained by each, respectively, was less than $1.0 \%$ in both stepwise and backward-step regression models. Although SNI 6 (School Worships) by itself explained $18.6 \%$ of the total varlance of student spirituality (See Table 12), the small change in the RSQ (.0097) in the stepwise model (See Table 13) appears to be largely due to its high correlation with predictors SNI 9 (Weeks of Prayer .5242) and SNI 10 (Bible viasses .4476i. Therefore, the model selected included only the top three predictors SNI 9 (Weeks of Prayer), SNI 10 (Bible Classes), and SNI 11 (Home Environmental Influence) which explained 37.13\% of the total variance of student spirituality but omitted SNI 6 (Community Service), and SNI 2 (School Curriculum) because the changes in RSQ between steps three to flve were relatively small in relation to steps one to three and added little to the total variance explained (See Table 13).

Table 14 presents the zero-order correlation of each variable ( $r)$; 1ts relative strength as a predictor of spirituality (Beta); and its unique contribution to the variance explained in the three predictor model (Unique RSQ). While the correlation of the selected variables is significant and their relative strength as predictors is 
TABLE 14

UNIQUE CONTRIBUTION OF VARIABLES IN MODEL

\begin{tabular}{lllll}
\hline SNI Dimension & $\boldsymbol{r}$ & Beta & $\begin{array}{c}\text { Unique } \\
\text { RSQ }\end{array}$ \\
\hline SNI 9 Weeks of Prayer & .5098 & .2075 & $9.82 \%$ \\
SNI 10 Bible Class & .4390 & .1965 & $6.37 \%$ \\
SNI 11 Home Environment & .3348 & .1394 & $4.44 \%$ \\
\hline
\end{tabular}

Beta = Standardized Regression Coefficients

Unique RSQ = Decrease in varlance if removed 


\section{5}

low but stable (similar ratios between $I$ and beta), their unique contribution to the variance explained is moderate.

This result suggests that when the SNI dimensions are considered together as predictors of "student spirituality," the best model includes Weeks of Prayer. Bible Classes and the Home Environmental Influence.

\section{Relationship between student Spirituality (SI Scores) and School Spiritual Nurture (SNI Means)}

The data of the study were analyzed to determine whether there were any significant relationships between "student splrituality" (SI scores) and "school spiritual nurture" (SNI means). However, the low correlations suggested that the relationships were not meaningful.

While there were significant correlations between 9 of the 10 SNI dimensions, the percentage of variance of student spirituality explained by each SNI dimension was extremely low. Both forward-step and backward-step regression models were analyzed but each were found to be unstable and to predict low total variance. The apparent instability between models was probably due to the high inter-correlations between SNI variables and the small difference in the variance explained between the highest and lowest SNI dimension. The low total variance explained by each model is probably due to two situations. First, the low variance may be the result of attempting to predict student differences in spirituality from school 
characteristics alone. It is evident that there are many other variables which impact student spirituality. Second, the low variance may also be the result of attempting to predict large differences of spirituality found "within schools" from small differences of spiritual nurture "between schools." This suggests that it is probably inappropriate to attempt to predict "student spirituality" from the school means of spiritual nurture.

Relationship between School Spirituality (SI Means) and School spiritual Nurture (SNI Means)

Table 15 presents the simple (zero-order) correlations between school SI means and school SNI means. The .05 level was used to test for significance. Five SNI dimensions (SNI 2, 6, 9, 10, 11) were significantly correlated with student spirituality with correlations ranging between .5058 and .6445 . The percentage of variance of student spirituality explained by each significant SNI dimension ranged between $25.6 \%$ and $41.5 \%$. Those which explained the highest levels of variance included: SNI 10 (Bible Class) 41.5\%: SNI 2 (School Curriculum) 27.0\%: SNI 9 (Weeks of Prayer) 25.9\%; SNI 6 (School Worships) 25.9\%; and SNI 11 (Home Environmental Influence) $25.6 \%$ (See Table 15). The correlation matrix also revealed four high correlations between SNI dimensions: Teaching Methodology and Teacher spirituality .8266: School Curriculum and Teaching Methodology .7624; 
TABLE 15

$$
\begin{gathered}
\text { CORRELATION BETWEEN SCHOOL SI MEANS } \\
\text { AND SCHOOL SNI MEANS }
\end{gathered}
$$

\begin{tabular}{ccc}
\hline $\begin{array}{c}\text { SNI } \\
\text { Dimension }\end{array}$ & Correlation & $\begin{array}{c}\text { Variance } \\
\text { Explained }\end{array}$ \\
\hline 1 & .2921 & $8.5 \%$ \\
2 & $.5204^{*}$ & $27.0 \%$ \\
3 & .3362 & $11.3 \%$ \\
4 & .0352 & $0.1 \%$ \\
5 & .1279 & $1.6 \%$ \\
6 & $.5088^{*}$ & $25.9 \%$ \\
7 & -.3463 & $12.0 \%$ \\
8 & .2369 & $5.6 \%$ \\
9 & $.5084^{*}$ & $25.9 \%$ \\
10 & $.6445^{*}$ & $41.5 \%$ \\
11 & $.5058^{*}$ & $25.6 \%$ \\
\hline
\end{tabular}

* Denotes significance at the .05 level Variance Explained $=r^{2} \times 100$ 
School Curriculum and Teacher Spirituality .5998; Bible Teacher Spirituality and Bible Classes .7637.

In view of the difficulty of separating the function of the Bible teacher from the Bible class, it was not surprising to find a high correlation between both dimensions. This suggests that the success of the Bible class in nurturing student spirltuality includes the Bible teacher's personal approach and spirituality. The results of the correlation of "school spirituality" and school spiritual nurture shown in Table 15 indicate a negative relationship between community Service (SNI 7) and "school spirituality" (-.3463). It appears that the reason for this negative correlation is largely due to the unusual results in three schools: School 1 (SI rank 12 with SNI 7 rank 1). School 11 (SI rank 19 with SNI 7 rank 3) and School 16 (SI rank 9 with SNI 7 rank 19) (See Table 11). While it is difficult to explain this negative correlation, it seems probable that while service activities are perceived as nurturing experiences in Schools 1 and 11 , other important areas of spiritual nurture are either neglected or are counterproductive. resulting in low student spirituality levels in those schools. It also seems likely that school 16, where the spirituality level is moderate, does not actively promote or undertake service activities in the school program. Using school SNI and SI means, both stepwise and backward-step regression were employed to ascertain which 
SNI dimensions were likely best to predict school spirituality. Table 16 presents a stepwise regression model of four predictors (SNI 10, 11, 8, 2) which explains 79.58\% of the total variance of school spirituality. The analyses added predictors in order of highest partial correlations with an $F$ ratio above 4.00 which approximates the .05 level. In this model. SNI 10 (Bible class) accounted for $41.54 \%$ of the variance of "school spirituality," SNI 11 (Home Environmental Influence) an additional 16.64\%; SNI 8 (Bible Teacher Spirituality) an additional 14.72\%; and SNI 2 (School Curriculum) an additional $6.68 \%$.

Table 17 presents the zero-order correlation of each variable ( $r$ ): its relative strength as a predictor of spirituality (Beta); and its unique contribution to the total varlance explained in the four predictor model (Unique RSQ). While variables SNI 10 (Weeks of Prayer). SïI il ï̈unc Environmental Influence), SNI 2 (School Curriculum) are highly correlated, are strong predictors. and contribute significantly to the total variance explained, variable SNI 8 (Btble Teacher Spirituality) is an unstable predictor because by 1 tself it is not significant (See Table 15) but when considered with other predictors in the model it has a high but negative beta value (See Table 17).

Table 18 presents a backward-step regression model of four predictors (SNI 11, 2, 5, 2) with a total varlance 
TABLE 16

SCHOOL SPIRITUALITY STEPWISE SELECTION USING SCHOOL SNI MEANS

\begin{tabular}{ccccc}
\hline $\begin{array}{c}\text { Step } \\
\text { No. }\end{array}$ & $\begin{array}{c}\text { Var. } \\
\text { Added }\end{array}$ & $\begin{array}{c}\text { Var.in } \\
\text { Model }\end{array}$ & RSQ & $\begin{array}{c}\text { Change } \\
\text { in RSQ }\end{array}$ \\
\hline 1 & 10 & 10 & .4154 & .4154 \\
2 & 11 & 10,11 & .5818 & .1664 \\
3 & 8 & $10,11,8$ & .7289 & .1472 \\
4 & 2 & $.10,11,8,2$ & .7958 & .0668 \\
\hline
\end{tabular}

- Denotes the model selected

TABLE 17

UNIQUE CONTRIBUTION OF VARIABLES IN MODEL

\begin{tabular}{|c|c|c|c|c|}
\hline & SNI Dimension & $\mathbf{r}$ & Beta & $\begin{array}{l}\text { Un Ique } \\
\text { RSQ }\end{array}$ \\
\hline $\begin{array}{l}\text { SNI } \\
\text { SNI } \\
\text { SNI } \\
\text { SNI }\end{array}$ & $\begin{array}{l}10 \text { Bible Class } \\
11 \text { Home Environment } \\
8 \text { Bible Teacher } \\
2 \text { School Curriculum }\end{array}$ & $\begin{array}{l}.6445 \\
.5058 \\
.2369 \\
.5204\end{array}$ & $\begin{array}{r}.8795 \\
.4177 \\
-.6857 \\
.3462\end{array}$ & $\begin{array}{l}27.65 \% \\
16.92 \% \\
18.61 \% \\
6.68 \%\end{array}$ \\
\hline
\end{tabular}

Beta = Standardized Regression coefficients Unique $R S Q=$ Decrease in varlance if removed 
TABLE 18

\section{SCHOOL SPIRITUALITY BACKWARD SELECTION} USING SCHOOL SNI MEANS

\begin{tabular}{lccc}
\hline $\begin{array}{l}\text { Varlable } \\
\text { In Model }\end{array}$ & $\begin{array}{l}\text { Varlable } \\
\text { Removed }\end{array}$ & RSQ & $\begin{array}{l}\text { Change } \\
\text { In RSQ }\end{array}$ \\
\hline $1-11$ & - & .8612 & -.8612 \\
$1-8,10,11$ & 9 & .8612 & -.0000 \\
$1-5,7,8,10,11$ & 6 & .8602 & -.0010 \\
$1-5,7,10,11$ & 8 & .8555 & -.0048 \\
$1-5,7,11$ & 10 & .8425 & -.0130 \\
$1,2,4,5,7,11$ & 3 & .8059 & -.0366 \\
$1,2,5,7,11$ & 4 & .7797 & -.0262 \\
$2,5,7,11$ & 1 & .7060 & -.0738 \\
& & & \\
\hline
\end{tabular}

* Denotes model selected 
explained of $70.58 \%$. The analyses removed predictors in order of lowest partial correlations with an $F$ ratlo below 4.00 which approximates the .05 level. In this model, the change in the variance explained fell by less than $1.0 \%$ through each of the first three backward steps and by an overall 7.0\% with the completion of the backward selection. Table 19 presents the zero-order correlation of each varlable ( $r)$; Its relative strength as a predictor of spirituality (Beta): and its unique contribution to the total variance explained in the four predictor model (Unique RSQ). Variables SNI 2 (School Curriculum) and SNI 11 (Home Environmental Influence! are highly correlated with "school spirituality," are strong predictors, and contribute significantly to the total variance explained. However, varlable SNI 5 (Teacher Spirituality) is an unstable predictor because by itself it has a positive but not significant correlation, yet when considered with other predictors in the model it has a signiflcant but negative beta value. SNI 7 (Community Service Outreach) is an unusual predictor because by itself it has a negative but not significant correlation and when considered with other predictors in the model it has a significant but also a negative beta value.

Whlle both forward and backward-step regression models explained a similar proportion of variance (stepwise 79.58\%, Backward 70.60\%), the only SNI variables common to both were SNI 11 (Home Environmental Influence) and SNI 2 
TABLE 19

UNIQUE CONTRIBUTION OF VARIABLES IN MODEL

\begin{tabular}{|c|c|c|c|c|}
\hline & SNI Dimension & $\mathbf{r}$ & Beta & $\begin{array}{c}\text { Unique } \\
\text { RSQ }\end{array}$ \\
\hline $\begin{array}{l}\text { SNI } \\
\text { SNI } \\
\text { SNI } \\
\text { SNI }\end{array}$ & $\begin{array}{l}2 \text { School Curriculum } \\
5 \text { Teachers } \\
7 \text { Community service } \\
11 \text { Home Environment }\end{array}$ & $\begin{array}{r}.5204 \\
.1279 \\
-.3463 \\
.5058\end{array}$ & $\begin{array}{r}.6428 \\
-.4102 \\
-.3857 \\
.5740\end{array}$ & $\begin{array}{l}26.07 \% \\
10.45 \% \\
13.24 \% \\
31.68 \%\end{array}$ \\
\hline
\end{tabular}

Beta = Standardized Regression Coefficients

Unfque $R S Q=$ Decrease in variance if removed 
144

(School Curriculum) (See Tables 17 and 19). The apparent instablity between the stepwise and backward models selected may be due to the high inter-correlations between the SNI variables.

The results of these regression models suggest that when the SNI dimensions were considered together as predictors of "student spirituality" the best model included the Home Environmental Influence (SNI 11), the Bible Class (SNI 10), and Weeks of Prayer (SNI 9). On the other hand, when considered together as predictors of "school spirituality" the best model included the Home Environment (SNI 11), Bible Class (SNI 10), School Curriculum (SNI 2).

Table 20 is a summary table of three regression models selected for this study. The table presents the stepwise and backward prediction models selected in both parts one (Student SI Scores and Student SNI Scores) and three (School SI Means and School SNI Means). It liste the zero-order correlations $(x)$, standardized regression coefficients (Beta), and the unique total varlance explained by each variable in the respective models (Unique RSQ) .

\footnotetext{
As the summary table reveals, there were seven significant predictors SNI 2 (School Curriculum), SNI 5 (Teacher Spirituality), SNI 7 (Community Service), SNI 8 (Bible Teacher Splrituality), SNI 9 (Weeks of Prayer), SNI 10 (Bible Classes), SNI 11 (Home Environmental
} 
SCMMARY TABLE OF SELECTED PREDICTION MOOELS

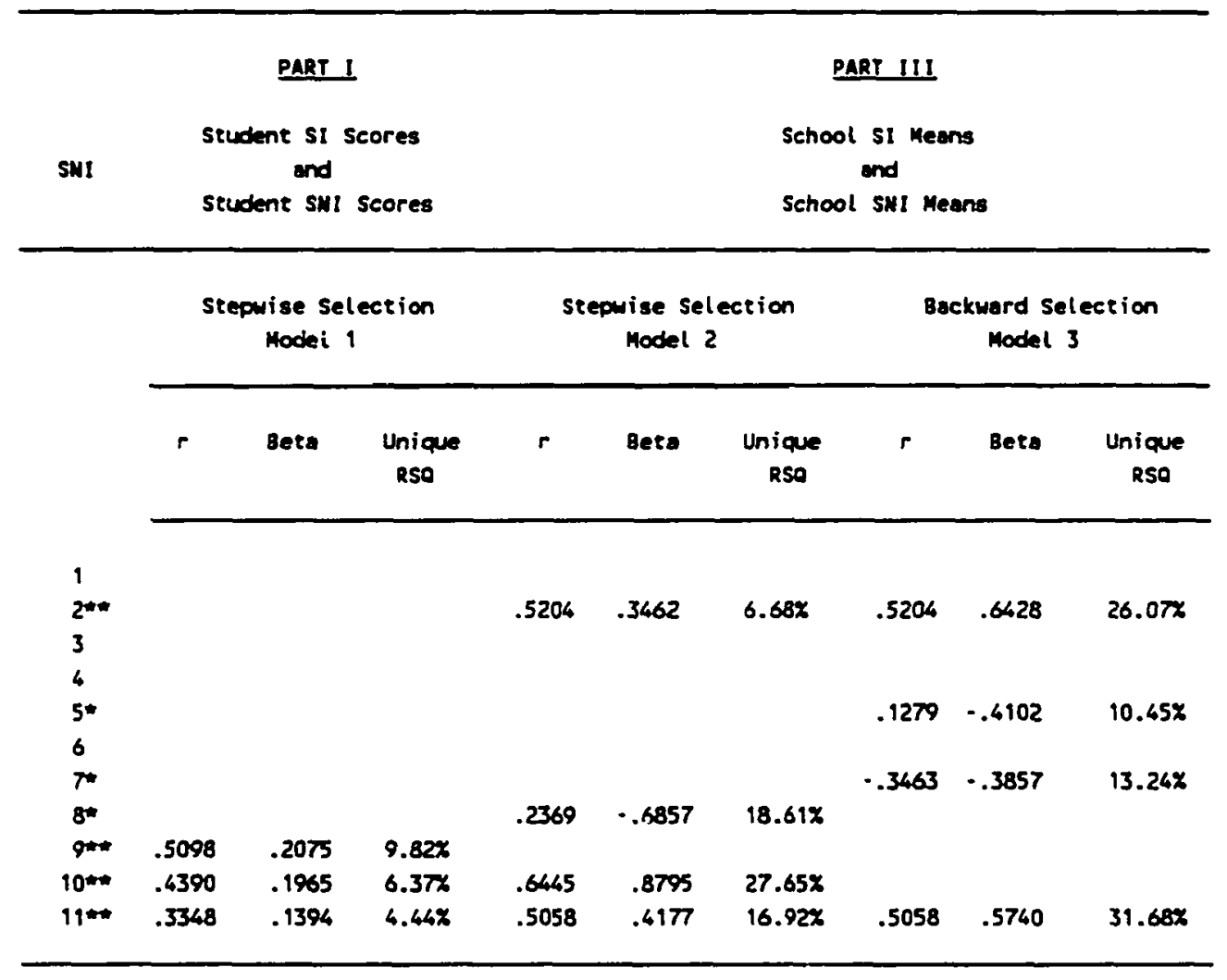

- Predictors significent but not maningful

- Predictors significane and meaningful

Reproduced with permission of the copyright owner. Further reproduction prohibited without permission. 
Influence), found in the three selected prediction models. However, although variables SNI 5 (Teacher Spirituality), SNI 7 (Community Service), and SNI 8 (Bible Teacher Spirituality) are statistically significant at the .05 level, they are not meaningful as predictors. That is, the negative Beta values underscore the unstable nature of the variables as predictors, while the low correlations for each and the negative correlation of SNI 7 (Community Service) suggests that they have limited practical value in predicting student spirituality.

on the other hand, variables SNI 11 (Home

Environmental Influence), SNI 10 (Bible Classes), SNI 2 (School Curriculum), and SNI 9 (Weeks of Prayer) appear to have a strong basis for being meaningful predictors of spirituality. SNI 11 (Home Environmental Influence) appears in all three models with high correlations, has strong Beta values in at least two models, and has high unique predictive values in two models. SNI 10 (Bible Classes) appears in two models with high correlations, has one strong Beta value, and has high unique predictive values in both models. SNI 2 (School Curriculum) appears in two models with high correlations, has strong Beta values, and has high unique predictive power in one model. Although SNI 9 (Weeks of Prayer) appears only in one model and has only a moderate Beta value, its high correlation with "student spirituality" and high unique predictive 
power in the context of Model one suggests that it may also be a meanfingful predictor of "student spirituality."

\section{Implications for Educational Administrators}

This section discusses the findings of the study as they apply to Christian educational administrators.

\section{Principal spirituality}

The results of the study revealed that there was a statistically significant relationship between Principal Spirituality and "student spirituality." Although differences "between schools" were moderate (See Table 9), the correlation with "student spirituality" was low (See Table 12 ), suggesting that students did not perceive the spiritual life of the principal to be strongly related to their personal spirituality.

Nevertheless, it was perceived that principals fostered spirituality when their life and actions in tise school were consistent with the principles of Christianity, when they assumed spiritual leadership responsibilities in the school, and when they shared experiences of their spiritual journey with students. It is also probable, according to Loveless (1984), that principals who are preoccupied with managerial tasks, disciplinary problems, and budgetary concerns, are less likely to enhance student spirituality than principals who devote more time and energy to spiritual nurture. A principal's influence 
therefore may be a reflection of the depth of personal spirituality, overwork, or both.

It was surprising, however, that Principal spirituality was not found to be strongly related to higher levels of student spirituality. A re-examination of the Principal spirituality scale and the respective items verifled its reliablity and validity. It appears then, that reasons for this anomaly are due to other factors. It is possible, for example, that students had difficulty in making strong discriminating judgments about the spirituality of the principal due to their general remoteness from the principal. Interaction between the principal and students is often limited to school assemblies and chapel periods.

\section{School Curriculum}

The results of the study revealed that there were statistically significant relationships between the school Curriculum and both "student" and "school" spirituality. While differences "between schools" were moderate (See Table 9), there was a low correlation with "student spirituality" (See Table 12), but a very high correlation with "school spirituality" (See Table 15). This latter finding resulted in it being one of the three major predictors of higher levels of "school spirituality" (See Table 20). These findings suggest that while students did not perceive the curriculum to be strongly related to their 
personal spirituality, they belleved that it had a strong relationship to the level of "school spirituality." Accordingly, students strongly perceived that school curricula fostered spirituality in the school when Christian principles were readily observed in extracurricula activities, when school personnel were percelved to place considerable importance on religious activities. and when Bible study groups were actively fostered in the school.

\section{Teaching Methodology}

The results of the study revealed that there was a statistically significant relationship between Teaching Methodology and "student spirituality." However, differences "between schools" were small (See Table 9), and the correlation with "student spirituality" was low (See Table 12), suggesting that students did not perceive teaching strategies to be strongly related to their personal spirituality.

Yet the students perceived that the methods employed by teachers in the classroom fostered spirituality when the principles of Christianity and Scripture were alluded to in class, when students were encouraged to help one another, and when teachers showed respect for student individuality. 


\section{School Discipline}

The results of the study revealed that there was a statistically significant relationship between school Discipline and "student spirituality." However, differences "between schools" were small (See Table 9), and the correlation with "student spirituality" was low (See Tabie 12), suggesting that students did not perceive the approach and emphasis in school disciplinary matters to be strongly related to their spiritual growth.

Notwithstanding, students percelved that school disciplinary policy fostered spirituality when administrators and teachers had a positive approach to student behavior, demonstrated trust and respect for students, Invited students to participate in establishing and Implementing school sules, and were forgiving and patient in working with students who had done wrong.

\section{Teacher Solrituality}

The results of the study revealed that there was a statistically significant relationship between Teacher Splrituality and "student spirituality." However. differences "between schools" were small (see Table 9), and the correlation with "student spirituality" was low (See Table 12), suggesting that students did not perceive the spiritual life of the teacher to be strongly related to their own spirituality. 
Nevertheless, students perceived that teachers fostered spirituality when their actions in the school were seen to be in harmony with the principles and values of Christianity, and when they were percelved to be enthusiastic about their relationship with Christ. It is also probable, according to shelton (1983), that teachers' avallabllity and willingness to cultivate friendships with students will have a large bearing on their effectiveness in nurturing student spiritual growth.

It was surprising, however, that Teacher Spirituality was not found to be strongly related to higher levels of student spirituality. A re-examination of the Teacher spirituality scale and the respective items verlfied its reliability and validity. It appears that students had difficulty in making strong discriminating judgments when teachers were considered as a group. While it is quite probable that some teachers within a school may have been perceived to be more spiritual than others, the differences would not necessarily be apparent when teachers were evaluated as a group.

\section{School Worshlps}

The results of the study revealed that there was a statistically signiffcant and strong relationship between School Worships and both "student" and "school" spirituality. Although differences "between schools" were small (See Table 9), the correlations with both "student" 
and "school" spifituality were high (See Tables 12 and 15). suggesting that students perceived School Worships to be strongly related to their personal spirituality and to the level of spirituality in the school. Yet, alarmingly, the low combined mean for School Worships (See Table 9) revealed that students in most schools perceived them to lack spiritual value.

Students strongly percelved that school worships enhanced personal spirituality and the level of "school spirituality" when a relationship with Christ was the central focus, when the material presented was perceived to be relevant and stimulating, and when student concerns were frequently considered in prayer.

\section{Community Service Outreach}

While differences in Community Service Outreach "between schools" were the largest of all SNI dimensions (See Table 9), the results revealed that there was a statistically significant but extremely weak relationstip with "student spirituality" (See Table 12). Surprisingly. there was also a negative correlation between community Service Outreach and "school spirituality" (See Table 15). While it seems that such activities are more common in some schools than others and vary in their effectiveness in nurturing social consclousness among students, this result suggests that students perceived service activities to have little bearing on their personal spirituality. 
While differences were expected, it was surprising to find a negative correlation. This peculiar relationship appears to be either a function of the Community Service outreach scale or the fact that there is wide variation in its implementation in schools. Despite the fact that the scale itself and all items in the scale were statistically reliable, only one item had a significant, albeit low, correlation with spirituality. This suggests that the result could reflect a weakness in the Community Service outreach scale, but it is also possible, that it reflects the fact that service activities are not a part of the curriculum in many schools.

\section{Bible Teacher spirituality}

The results of the study revealed that there was a statistically significant relationship between Bible Teacher Spirituality and "student spirituality." Differences "between schools" were large (See Table 9), and the correlation with "student spirituality" was moderate (See Table 12), suggesting that students perceived the life and the spiritual example of the Bible teacher to be moderately related to their personal spiritual growth. However, the high combined mean (See Table 9) suggested that students considered most Bible teachers to be deeply committed in their relationship with Christ.

Accordingly, students strongly perceived that Bible teachers enhanced spirituality when their actions were 
154

consistent with the principles of Christianity, when they shared experiences of their spiritual fourney with students, and when they were percelved to be concerned about leading students into a personal relationship with Christ. It also seems probable that enhancing "student spirituality" is a function of the Bible teacher's spiritual vitality (Betts, 1910), and of the differing employment practices among schools (Gaebelein, 1968). Some schools employ specialist Bible teachers while others require subject teachers to teach Bible as an adjunct to their teaching specialty. The instrument used in this study did not differentiate between Bible teacher employment policies in schools.

\section{Weeks of Prayer/Spiritual Emphasis}

The results of the study revealed that there was a statistically significant relationship between the Week of Prayer and "student" and "school" spirltuality. Although differences "between schools" were moderate (See Table 9), there were high correlations with both "student" and "school" spirituality (See Tables 12 and 15). This suggested that students perceived ine Week of Prayer to be strongly related to both their personal spirituality and to the level of spirituality in the school. Its high correlation with the spirituality of students, resulted in the Week of Prayer being one of three major predictors of higher levels of "student spirituality" (See Table 20). 
Accordingly, students strongly perceived that the Week of Prayer enhanced their personal spirituality and the level of spirituality in the school when it addressed issues of practical Christian living, when the focus centered on the relationship with christ rather than church doctrine, and when presentations were bullt around adolescent concerns.

\section{Bible Classes}

The results of the study revealed that there was a statistically significant and strong relationship between Bible classes and "student" and "school" spirituality. Differences "between schools" were high (See Table 9), and correlations with "student" and "school" spirituality were also high (See Tables 12 and 15 ), resulting in Bible classes being one of three major predictors of higher levels of both "student" and "school" spirltuality (See Table 201. This suggested that students perceived the approach and emphasis in Bible Classes to be strongly related to their personal spirituality and to the level of spirituality in the school.

Students strongly suggested that Bible Classes

enhanced their personal spirituality and the level of spirituality in the school when Bible curricula centered on the relationship with Christ, when Bible curricula addressed adolescent developmental issues, and when Bible study skills were often demonstrated to enhance personal 
devotions. While the Bible Classes scale did not include the issue of prayer, it seems probable that Bible Classes would foster student spirituality if the meaning and practice of prayer was incorporated into the Bible class curricula (Stanley, 1985).

\section{Home Environmental Influence}

This dimension was incorporated in the study in order to ascertain the influence and the impact of the home environment on adolescent spirituality. The results overwhelmingly confirmed the expectation that the home plays a very important role in the spiritual nurture of young people.

The results of the study revealed that there was a statistically significant and strong relationship between the Home Environmental Influence and both "student" and "school" spirituality. Although differences between schools were small (See Table 9), Its high correlation with both "student" and "school" spirituality (see Tables 12 and 15). resulted in it being one of three major predictors of higher levels of both "student" and "school" spirituality (See Table 20). This suggested that students perceived the home to have a very strong relationship to their personal spirituality and to the level of spirituality in the school.

Accordingly, the home environment was strongly perceived to foster personal spirituality and the level of 
spirituality in the school when parents were actively involved in church activities, when parents shared experiences of their spiritual journey with them, and when parents modeled a lifestyle in harmony with the principles of Christianity.

\section{Summary}

In response to Hypothesis 1 , the results suggest that there were significant differences in the levels of spirituality among seventh-day Adventist day academies in the United States. However, differences in spirituality were small suggesting considerable similarity "between schools." Notwithstanding, the results still provided a basis for identifying significant relationships between dimensions of spiritual nurture and higher levels of spirituality.

In response to Hypothesis 2 , the results suggest that there were significant differences in the levels of spiritual nurture among Seventh-day Adventist day academies in the United States. Differences occurred in the levels of spiritual nurture both "between" and "within" schools. First, the most pronounced "between school" difference of spiritual nurture was Community Service while the smallest "between school" difference was Home Environmental Influence. The most meaningful "between school" difference was the perception that the Bible Teacher, Bible Class, and Weeks of Prayer were areas of greatest spiritual nurture, 
while School Worships and Community Service, as the students knew them, were areas of least spiritual nurture. second, spiritual nurture "within schools" varied considerably. Spiritual nurture was rated consistently high in three schools, consistently low in seven schools. and inconsistently rated in nine schools. It was also found that when comparing both areas of spirituality and spiritual nurture ratings "within schools," three schools had high ratings, eight schools had moderate ratings, five schools had low ratings, and six schools were inconsistently rated.

In response to Hypothesis 3 and on the basis of the above results, there were significant relationships first, between spiritual nurture and "student spirituality" (student SI scores) and, second, between spiritual nurture and "school spirituality" (school SI means). Birst, when considered alone, for purposes of estimating their impact on the personal spirituality of students, all SNI dimensions were found to have a significant relationship to "student spirituality," although, students perceived that School Worships, Weeks of Prayer, Bible Classes, and the Home Environmental Influence had greatest impact on their lives. When considered together as predictors of "student spirituality." the best model included the Home Environmental Influence (SNI 11), the Bible Class (SNI 10), and Weeks of Prayer (SNI 9 ). 
159

Second, when the SNI dimensions were considered alone, for purposes of estimating their impact on the level of "school spirituality." students percelved that school Curriculum (SNI 2), School Worships (SNI 6), Weeks of Prayer (SNI 9), Bible Classes (SNI 10), and Home Environmental Influence (SNI 11) had greatest impact on the school. When considered together as predictors of "school spirituality," the best model included the Home Environment (SNI 11), Bible Class (SNI 10), and School Curriculum (SNI 2).

The educational administrative implications of these results suggest that students believe that school Worships, Bible Teacher Spirituality, Weeks of Prayer. Bible Classes, and the Home Environment to be strongly related to "student spirituality." They also believe that the School Currtculum, School Worships, Weeks of Prayer, Bible Classes, and the Home Environment to be strongly related to higher levels of "school spirituality." 
CHAFTER $V$

SUMMARY, FINDINGS, IMPLICATIONS, AND RECOMMENDATIONS

This chapter presents a summary of the study and the findings, a discussion of the implications for Christian educational administrators, and recommendations for enhancing student spirituality in Christian education. Areas for further research are suggested at the close of the chapter.

\section{Summary}

As a response to the twin goals of Christian education--leading students into a personal relationship with Christ and nurturing student spirituality, this study attempted to discover (1) possible differences in spirituality and spiritual nurture between seventh-day Adventist day academies in the United States, (2) possible relationships between selected dimensions of Christian education and student spirituality, and (3) the implications for educational administrators.

The review of literature provided a theoretical background for the study and a basis for developing the Spirituality Inventory (SI) and the Spiritual Nurture Inventory (SNI). In section one, 10 dimensions of 


\section{'5:}

Christian spirituality were explored from a purposeful sample of some 35 Christian spiritual masters: meditation. prayer, study, confession, submission, solitude, service, worship, guidance, and joyfulness. Reflecting the collective thought of the Christian educational theorists and practitloners reviewed in section two, 10 leading dimensions for nurturing student spirituality were identifled: principal spirituality, school curriculum, teaching methodologies, school discipline, teacher spirituality, school worships, community service outreach, Bible teacher spirituality, weeks of spiritual emphasis, and Bible classes.

Seventh-day Adventist day academies in the United states constituted the population for the study. Twenty day academies with student enrollments above 50 were randomly selected from the 40 day academies in the united States. Of the 20 day academies and 753 seniors selected, 19 day academies with responses from 591 seniors returned the SI and the SNI for analysis.

Two Likert styie attitudinal scales were developed for the study. First, the Spirituality Inventory (SI) was designed to measure the implied level of student spirituality, and second, the spiritual Nurture Inventory (SNI) was designed to measure the level of spiritual nurture in each of the selected educational dimensions. In acknowledgment of the fundamental importance of the home, an $11^{\text {th }}$ dimension, "Home Environmental Influence," was 
added to the SNI. Content validity was established by two panels of five jurges, while statistical reliability for each scale was established by an item analysis of the results of data collected from three pilot studies. Rellability was confirmed through post-descriptive item and factor analysis using the study data. The SI scale was analyzed for overall reliability with the assumption that the dimensions identified in the literature were 10 content areas of one construct, namely, spirituality. The SNI, on the other hand, was analyzed in terms of the reliability of each educational dimenston of spiritual nurture. The reliability coefficient for the SI scale was .9343, while the rellability coefficients for each of the dimensions in the SNI ranged between .5875 and .8055 .

In response to the three fundamental concerns of this study, the results were presented in three sections. The first section presented and analyzed the data concerning differences in the levels of spirituality and of spirltual nurture among Seventh-day Adventist dä scadこ: in the United States. In response to Hypothesis 1 , significant aifferences in the levels of spirituality were found among the schools studied. In response to Hypothesis 2 , significant differences in the levels of spiritual nurture were found both "between" and "within" the schools studied.

The second section presented and analyzed the data concerning the possible relationships between the 
dimenslons of spiritual nurture and student spirituality among Seventh-day Adventist day academies in the United states. In response to Hypothesis 3 , significant relationships were found between all the dimensions of Christian education studied and "student spirituality" and/or "school spirituality," although some were more strongly correlated than others.

The third section summarized the findings of the study concerning the selected dimensions of spiritual nurture and discussed the implications for educational administrators. The results suggested that students percelved School Worships. Bible Teacher Spirituality, Weeks of Prayer, Blble Classes, and the Home Environment to be strongly related to higher levels of "student spirituality," and percelved School Curriculum, School Worships, Weeks of Prayer, Bible Classes, and the Home Environment to be strongly related to higher levels of "school spirituality."

\section{Findings}

On the basis of the data collected in seventh-day Adventist day academies in the United States, the following findings are summarized:

1. There were small differences in the levels of spirituality between schools, although, overall levels of spirituality were moderately high. 
2. There were large differences in the levels of spiritual nurture both between and within schools.

3. There were large differences in the nurturing impact of principals, Bible teachers, Bible classes, and communtty service programs between schools.

4. There was no significant difference in the nurturing impact of the home between urban and rural schools.

5. There was a strong relationship between the spirituality of the Bible teacher and the nurturing impact of the Bible class.

6. The nurturing effects of sohool curriculum, teaching strategles, and teacher spirituality were strongly related to each other.

7. Students perceived that School Worships, Weeks of Prayer, Bible Classes, and Home Environmental Influence had the greatest impact on their personal spirituality.

8. Students percelved that school Curriculum, School Worships, Weeks of Prayer, Bible Classes, and Home Environmental Influence had the greatest impact on the level of spirituality in the school.

9. The Home Environmental Influence, Bible Classes, and Weeks of Prayer were found to be the major predictors of higher levels of "student spirituality."

10. The Home Environmental Influence, Bible classes, and school Curriculum were found to be the major predictors of higher levels of "school spirituality." 


\section{Discussion and Implications}

The study has both $\bar{p} \bar{I} \in d i c t a t l e$ and unexpectad conclusions. The study confirmed that there were significant differences in levels of spirituality and spiritual nurture between Seventh-day Adventist day academies in the United States. Although differences in levels of spirituality "between schools" were small. overall levels of spirituality were moderately high. This result provided a basis for identifying significant relationships between the selected dimensions of spiritual nurture and higher levels of spirituality.

It was alṣo not surprising to discover differences in levels of spiritual nurture "within schools." It seems that in some schools spiritual nurture is strong in certain areas and weak in others. This situation may be a function of strong spiritual leadership in some areas of the educational program or a function of the tendency in some schools to compartmentalize the spiritual and the secular. While the findings of the study revealed significant relationships between all the dimensions of Christian education studied and "student spirituality," some were more strongly related than others. When the 11 dimensions of spiritual nurture were considered separately. for purposes of estimating their impact on the spirituality of students, all were found to have a significant relationship with "student spirituality," although, students perceived that school Worships, Weeks of Prayer, 
Bible Classes, and Home Environmental Influence had greatest impact on their lives. They also believed that School Currlculum, School Worships, Weeks of Prayer, Bible Classes, and Home Environmental Influence had the greatest impact on the level of spirituality in the school.

similarly, when the 11 dimensions were considered together as a group, for purposes of determining the best prediction model, the Home Environmental Influence, Bible Classes, and Weeks of Prayer were found to be the major predictors of higher levels of "student spirituality." while Home Environmental Influence, Bible Classes, and school Curriculum were found to be the major predictors of higher levels of "school spirituality."

According to these student perceptions, a number of important educational administrative implications for enhancing both "student and "school" spirituality became apparent.

on the basis of the Principal spirituality scale, if principals are to be recognized as strong spiritual leaders, they need to exemplify a life of devotion to God. to maintain visible involvement in the spiritual life of the school, and to share experiences of their spiritual journey with students. Grissen (1981/82) also suggested the need for principals to devote more time and energy to nurturing faculty and student spirituality, while Bennis \& Nanus (1985) and Morphet (1982) suggested the need to adopt 
leadership and management strategies which provide a learning environment conducive for personal growth. According to the school Curriculum scale, both administrative and teaching personnel need to recognize the importance of their attitudes and active involvement in the religious activities of the school, to foster actively and participate with students in Bible study groups, and to ensure that all extra-curricula activities of the school are in harmony with the school's Christian philosophy of education. Educational theorists also suggested the need for school curriculum personnel to underscore the important features of Christian education philosophy in school curricula by emphasizing: that all truth originates with God (Gaebelein, 1968), that the Bible is the foundational and contextual document of the curriculum (Holmes, 1975), that Christ is the integration point for all christian educational effort (Walworth, 1981), and that the student should be the focal point of the educational process (Sanderson, 1979).

Based on the Teaching Methodology scale, teachers should be encouraged to integrate faith and learning throughout subject matter, to foster cooperation rather than competition among students, and to accommodate student individuality through more personalized instruction. Educational cheorists also suggested the need for teachers to utllize more fully the sources of revelation, reason, and experimentation (Byrne, 1977), to cultivate reflective 
168

and independent thought (Knight, 1980), and to adopt teaching strategies which reflect more fully the cognitive, emotional, and moral readiness of students (Shelton, 1983). According to the school Discipline scale, administrators and teachers need to approach student behavior positively, and to be fair, trusting and respectful of student rights. They need to involve students in establishing and implementing school rules, and they need to be forgiving and patient with students who have done wrong. The literature also suggested the need to articulate the philosophy and goals of school discipline to students (Hilde, 1976), to adopt strategies which lead to internalization of moral princlples and values (Dobson. 1970), to uphold the principles of love and justice (Canter, 1982), and to foster a positive and open school/classroom environment (Johnson \& Johnson, 1975). Educational administrators need not only to foster spirituality among faculty members (Grissen, 1981/82), but nect to encourage them in their collective responsibility of leading students into a personal relationship with Christ. On the basis of the Teacher spirituality scale, they need to be encouraged to model a life whish is in harmony with the values and principles of Christianity, and to share experiences of their spiritual journey with students. Educational theorists also suggested the need for teachers to give priority to students concerns (Shelton, 1983), to think and communicate through a 
Christian mind-set (Blamires, 1963), and to cultivate personal relationships with students (Dudley, 1979). Based on the school worship scale, educational administratcrs, teachers, and school chaplains need to adopt strategies which ensure that classroom worships and chapel services address the spiritual needs of students. Accordingly, personnel responsible for worships should ensure that they center on the relationship with christ, address relevant concerns of adolescents, are sufficiently flexible in meeting the current and changing needs of young people, and use the opportunity to pray for and with students.

$$
\text { It is difficult to make any conclusive comment }
$$
regarding the relationship of Community Service Outreach to student spirituality. However, while the results of the study are cause for re-examining the impact of Community Service Outreach on student spirituality, the literature identified a number of ways in which service activities might be better employed to nurture spiritual growth. Some of the more important strategies included: cultivating an open environment of sharing in the school (Devnich, 1981), incorporating a wide range of service projects and activities in the curriculum (Morgan, 1986), inviting community service personnel into the school (Carey, 1977). and adopting strategles which specifically nurture social consclousness (Shelton, 1983). 
In view of the extreme importance of the role of the Bible teacher and Bible class curricula, educational administrators need to employ Bible teachers who are personally and professionaliy qualified to create a spiritual environment likely to result in students seeking a deeper relationship with Christ. According to the Bible Teacher spiritiality scale, Blble teachers should be people who feel free to share experiences of their spiritual journey with students, who give priority to leading students into a personal relationship with Christ, and who live a life in harmony with the principles and values of Christiantty. The literature also underscored the need for Bible teachers to be people deeply committed to Christ (Betts, 1910), and people who have exceptionally good rapport with young people (Knittle 1981), and who give priority to building quality relationships with students (Manspeaker, 1985).

on the basis of the Bible classes scale, Bible instruction needs to center on the stucient's relationship with Christ, to address adolescent ievelopmental issues, and to demonstrate the practice and methods of Bible study. The literature also emphasized the need to demonstrate the practice and methods of prayer (Stanley, 1985), and to facilitate an environment of open sharing in the Bible classroom (Hay, 1983).

In view of the very strong relationship between the week of Prayer and "student" and "school" spirituality. 
educational administrators need to give priority to seeking ways in which the Week of Prayer can become a more effective instrument of student spirituality. Based on the Week of Prayer scale, Weeks of Prayer need to be Christcentered, to be concerned with practical Christian living, and to illustrate how a relationship with Christ addresses adolescent concerns. Bower (1985) also suggested the need to maximize student involvement in organizational planning and presentation of such occasions.

Finally, educational administrators need not only to recognize the considerable importance and impact of the home in nurturing spirituality, but to seek actively ways the home and school can work more closely toward the common goal of leading young people into a closer relationship with Christ. On the basis of the Home Environmental scale, parents need to be made aware of the importance of their active involvement in church activities, of sharing experiences of their spiritual journey with their family. of modelling a lifestyle in harmony with the principles and values of Christianity, of modelling a private devotional Ilfe, and the need to have regular family worship with their children. 


\section{Recommendations}

On the basis of the findings of the study, the following recommendations are suggested:

1. It is recommended that school administrators in conjunction with faculty, give consideration to the findings that have been demonstrated to be assoclated with higher levels of spirituality.

2. It is recommended that Bible teachers give consideration to the factors shown to be instrumental in nurturing student spirituality inside and outside the Bible classroom.

3. It is recommended that Christian educators should give greater emphasis to the home as a primary agent in nurturing the spirituality of young people, to ways the home and school can work more closely for the spiritual growth of students, and to ways of helping parents nurture spirituality within the home.

\section{For Further Research}

In view of the above findings, implications, and recommendations, the following are issues suggested for further research:

1. A study to determine the relationship between the spirituality of the Bible teacher and the Bible class, and the impact they each have on student spirituality. 
2. A study to determine whether specialist Bible teachers are significantly more effective than teachers who teach Bible as an adjunct to their teaching specialty.

3. A study to determine the effectiveness of Bible classes with particular reference to the material presented, the degree to which it addresses the developmental needs of young people, the centrality of Christ and scripture, and the emphasis given to cultivating personal Bible study skills and the practice of prayer.

4. A study to determine how adolescent developmental concerns can be more effectively addressed to foster adolescent spiritual growth.

5. A study to establish more clearly the impact of the principal and teachers on student spirituality, and ways they can more effectively nurture spiritual growth.

6. A study to 1dentify ways the weeks of prayer and school worships can more effectively nurture spiritual growth in the school.

7. A study to identify ways parents can more effectively nurture spiritual growth in the home.

8. A study to establish more clearly the impact of service-outreach activities on student spirituality, and ways they can more effectively nurture spiritual growth. 


\section{APPENDIX 1}

INVENTORY ITEM ANALYSIS RESULTS

Reproduced with permission of the copyright owner. Further reproduction prohibited without permission. 


\section{SPIRITUALITY INVENTORY (SI) ITEM ANALYSIS}

Instrument Reliability Coefficient .9343

\section{Meditation .6672}

1. I often stop and think about my life from a Christian perspective. .7130

2. I spend some time each day thinking about the life of Jesus. . .7435

3. I seldom take time to reflect on God's blessings to me. .6558

4. I often meditate on Bible passages. .7276

\section{Prayer .2194}

1. I frequently taik to the Lord during the day. .7729

2. I often pray to be more like Jesus. .7533

3. I seldom recelve answers to my prayers. .6071

4. I have a special time of prayer at least once a day. .8054

\section{Study .7504}

1. When I study the Bible it often leads me to change things in my life. .2544

2. I'm not interested in memorizing Scripture. .7388

3. I enjoy sharing insights from my Bible study. .7587

4. I study Scripture so I can get to know Jesus better. .7790

\section{Confession .5250}

1. I regularly ask God's forgiveness. .6880

2. I'm not usually specific when I confess my sins. .5650

3. I experience peace after I've confessed my sins. .6956

4. I'm very aware of my need of God's forgiveness. .6562 
Solitude .7037

1. I often sense the presence of God even when preoccupied with other activities. .7679

2. During difficult times I spend a lot of time alone with God. .7462

3. I regularily choose to be alone with God. .7173

4. I seldom sense God's presence. .6815

\section{Submission .4757}

1. I often get upset when I don't get my own way. .5604

2. I place the interests of other people ahead of myself. .5978

3. I'm very happy when others succeed. .5477

4. I'm only nice to people if they're nice to me. .6901

\section{Service .4699}

1. I spend a lot of time helping people. .6533

2. I try to be friendly to people who don't have many friends. .6351

3. I get annoyed with people who interrupt what I'm doing. . .6300

4. I don't mind listening when people want to talk about their problems. .5887

\section{Worships .8275}

1. I enfoy worships because they bring me close to God. .7909

2. Attending church doesn't do mich for me. .8390

3. During church worship I often feel God speaking to me. .7908

4. I feel God's presence during church worship. .8383 
Guidance .7260

1. I'm frequently consclous of being led by God. .7541

2. I find little evidence that God has been guiding me. .7752

3. I'm a very independent person so I don't need to depend on God. .6932

4. I often seek guidance through the words of Scripture. . 7416

\section{Joyfulness $\quad .7611$}

1. I find joy in being a Christian. .8094

2. I often hum, whistle or sing Christian songs. 7046

3. Christianity makes me feel very happy. .8111

4. Christiantty helps me to be a very positive person. .7737 


\section{SPIRITUAL NURTURE INVENTORY (SNI) ITEM ANALYSIS}

Instrument Reliability Coefficient .9222

\section{Principal spifituality .7743}

1. The principal's actions in this school are often inconsistent with what christianity is all about. $\quad .7188$

2. The principal has led me closer to Jesus. .8128

3. The principal is a real spiritual leader in this school. . .6958

4. The principal is rarely enthusiastic about his/her relationship with Jesus. .7698

5. The principal is very concerned about leading students into a personal relationship with Jesus. .6418

\section{School Curriculum .5875}

1. Many teachers regard the religious activities as unimportant interruptions in the school program. .5550

2. Christian principles are usually applied to our extracurricular activities. .6687

3. Jesus Christ is obviously the central focus of the educational program in this school. .5020

4. The readings in English literature are consistent with the principles of Christianity. . 5375

5. Bible study groups are rarely encouraged in this school. . .6336

6. Apart from the Bible class, the Bible is seldom used in school. . .5313

\section{Teaching Methodology .6063}

1. The teachers seldom encourage students who are having problems. .5879

2. The teachers respect differences in students. 5145 
3. The teachers seldom point out the strengths of Christianity compared with secular society. .6200

4. The teachers seldom encourage students to help one another. .6164

5. The teachers include the Bible, where appropriate, in all the subjects they teach. .4692

6. The teachers usually commence classes with prayer. .6780

\section{School Discipline .7469}

1. Discipline in this school is very fair. .6802

2. Our teachers have a very negative approach to student behavior. .7033

3. Many of our teachers don't trust the students. .5209

4. Students are often invited to participate in

establishing the rules of this school. .7040

5. The teachers are very forgiving when dealing with students who have done wrong. .7275

6. School administrators don't respect the rights of students. .6586

\section{$\checkmark$ Teacher Spirituality .6772}

1. The teachers' actions in this school are oicen inconsistent with what Christianity is all about. .6748

2. The teachers (apart from the Bible teacher) have led me closer to Jesus. .6030

3. The teachers (apart from the Bible teacher) seldom make reference to their own personal Bible study. .4129

4. The teachers usually attend school worships. .6862

5. The teachers are rarely enthusiastic about their relationship with Jesus. .6938

6. The teachers (apart from the Bible teacher) are very concerned about leading students into a personal relationship with Jesus. .6210 
VI School Worships .6048

1. Worships in this school are often quite boring. .6059

2. The Bible is always used in school worships. .6362

3. Students are often encouraged to participate in prayer groups during school worships. .5160

4. Students' concerns are seldom prayed for during school worships. .6722

5. School worships have lead me into a deeper relationship with Jesus. .6900

\section{Community Service Outreach .7631}

1. Service/outreach activities are a low priority in this school. . 749 ?

2. The school schedule includes opportunities for service/outreach activities. .7418

3. Students are encouraged to give personal time towards service/outreach projects. .6874

4. The school has a mission-outreach fund-raising project involving staff and students. .6638

5. The school rarely participates in community-organized service projects. 7437

\section{The Bible Teacher .8002}

1. The Bible teacher's actions in this school are often inconsistent with what Christianity is all about. .8016

2. The Bible teacher has led me closer to Jesus. .7636

3. I feel comfortable in sharing my troubles with the Bible teacher because he/she understands. .6742

4. The Bible teacher is rarely enthusiastic about his/her relationship with Jesus. .7702

5. The Bible teacher is very concersed about leading students into a personal relationship with

Jesus. .7288 


\section{Weeks of Prayer .7951}

1. Weeks of Prayer help make the Bible relevant. .5086

2. Weeks of Prayer seldom talk about practical Christian living. .8230

3. Weeks of Prayer have deepened my personal relationship with Jesus. . 7614

4. Weeks of Prayer are often boring presentations of church doctrine. .8203

5. Weeks of Prayer have helped to make Christianity relevant. .7859

\section{B Bible Classes .8055}

1. Jesus Christ is usually the central focus in Bible classes. . 7490

2. Bible classes have helped me to better understand the meaning of life. .7807

3. Bible classes have lead me into a closer relationship with Jesus. 7962

4. Bible classes tell you how to live the Christian life. .6887

5. Bible-study skills are often demonstrated during Bible classes. . 7330

\section{Home Environmental Influence .7861}

1. We seldom have morning or evening worship in our home. .5715

2. My parents seldom have their own private daily devotions. $\quad .7594$

3. My parents are actively involved in church activities. . .7306

4. My parents seldom speak about their relationship with Jesus. . 7431

5. My parents model the principles of Christianity in their daily lives. .7100

6. My parents have taught me to be falthful in returning my tithe to God. .6720 
APPENDIX 2

SCHOOL CORRESPONDENCE

Reproduced with permission of the copyright owner. Further reproduction prohibited without permission. 


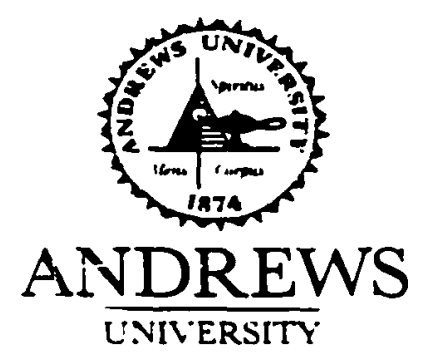

November 19,1986

Mr. Richard Osborn, Principal

Takoma Academy

8120 Carroll Avenue

Takoma Park, Maryland 20912

Dear Mr. Osborn:

I am writing to you because your school is one of twenty day academies randomly selected from the SDA Yearbook to particlpate in some doctoral research into student spirituality.

The objectives of the research are (1) to identify differences in the levels of spisitual nurture between Seventh-day Adventist day academies in North America, and (2) to identify the dimensions of Christian education which are most likely to eninance student spirituality.

To accomplish this goal, two instruments have been developed for the study: the Spirituality Inventory (SI) and the Christian Education Spiritual Nurture Inventory (SNI). They are to be administered to the senior class and will take approximately 20-25 minutes to complete.

PLEASE BE ASSURED THAT ALL RESPONSES OF STUDENTS WILL BE TREATED WITH COMPLETE CONEIDENTIALITY AND THE IDENTITY OE EACH ACADEMY SAMPLED WILL NOT BE REVEALED.

The instruments will be forwarded to you by Friday, January 5 and I would be gratefui if they could be administered during that week.

I will call you by telephone next Wednesday, November 26 to answer any questions you may have regarding inls research.

Thank you in anticipation of your helpful cooperation.

Yours sincerely,

Bruce R. Youlden

Ph.D Candidate, School of Education

$\overline{\text { Berrien Springs, Michigan }+910+/(616)+i 1-i 7 i 1}$ 
Eebruary 2, 1987

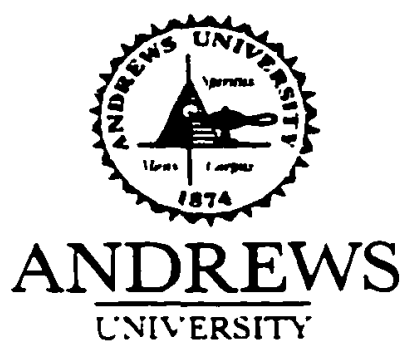

〔184!

Mr. Richard Osborn, Principal

Takoma Academy

8120 Carroll Avenue

Takoma Park, Maryland 20912

Dear Mr. Osborn:

Please find enclosed materlals pertaining to the research into student spirituality outlined in my letter $11 / 19 / 86$ and subsequently discussed with you by telephone.

Pardon the unexpected delay in forwarding these materials to you, but it was necessary to rus a third pilot study.

I would like to draw your attention to the instructions at the beginning of the questionaire. Following the distribution of the questionaires to the senior class, please read the instructions to the students and qive appropriate emphasis to the salient parts of each point.

I will appreciate if the questionaire could be administered as soon as convenient and returned the next day via United Parcel Service to my attention at the following address.

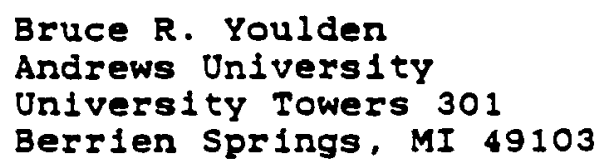

If you have any questlons relating to this research, please do not hesitate in contacting me by telephone:

$$
(616) \quad 471-3690
$$

Thank you very much for your cooperation and assistance in this research. I believe that the research addresses an important issue and it is my sincere desire that the results may be helpful to those committed to Christian Education.

At the conclusion of the study. I will forward a copy of the final chapter to you.

Yours sincerely,

Bruce R. Youlden

Ph.D Candidate, School of Education

Berrien Springs. Michigan $+9104 /(616)+7 i-7771$ 


\section{APPENDIX 3}

STUDENT SI AND SNI QUESTIONNAIRES

Reproduced with permission of the copyright owner. Further reproduction prohibited without permission. 
SPIRITUALITY INVENTORY (SI)

AND

SPIRITUAL NURTURE INVENTORY (SNI)

C Copyright 1988 by Bruce R. Youlden 
1. Please respond to each of the following statements with COMPLETE HONESTY. Your responses will be treated conf1dentially and YOUR IDENTIIY KIIL NOT BE KNOWN.

2. Respond to each of the statements by CIRCLING THE ABBREVIATION which most accurately reflects your experience.

Eor example:

I enjoy watching NFI football.

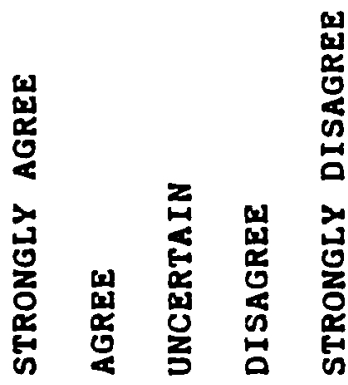

SA $A \cup D$ SD

3. ONLY use the response "uncertain" when you feel it is not possible to express your opinion as "strongly agree". "agree". "disagree" or "strongly disagree".

4. PLEASE DO NOT CONFER WITH EACB OTHER. HOWEVET, if you have any questions please feel free to ask your supervisor.

5. II WON'I BE NECESSARY TO RUSH YOUR ANSKERS bECaUSE you have at least 20-25 minutes to complete the guestionajre. If you flnish early PLEASE REMAIN QUIPTLY SEATED until everyone has flaished.

6. When you are finlshed CHECK TO SEE THAT YOU HAVE ANSWERED EVERY QUESTION.

Thank you for your particlpation. You are contributing to a study that is extremely important to the fleld of Christian Education.

Bruce R. Youlden

Ph.D Candidate

School of Education. Andrews University

January, 1987 
1. I often stop and think about my ilfe from a Christian perspective.

2. I Erequently talk to the Lord during the day.

3. When I study the Bible it often leads me to change things in my life.

4. I regularly ask God's forgtveness.

5. I often sense the presence of God even when preoccupied with other activities.

6. I often get upset when I don't get my own way.

7. I spend a lot of time helping people.

8. I enfoy worships because they bring me close to God.

9. I'm erequently conscious of being led by God.

10. I find foy in being a christian.

11. I spend some time each day thinking about the life of Jesus.

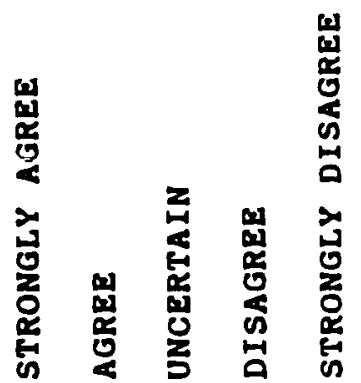

SA A U D SD

SA A - U D SD

SA A $U$ D $\quad$ SD

SA A $O$ D $\quad$ SD

SA A U D SD

SA A U D SD

SA A U D SD

SA A U D SD

SA A U D SD

SA A U D SD

SA A U D SD 
12. I often pray to be more like Jesus.

13. I'm not interested in merorizing Scripture.

14. I'm not usually specific when I confess my sins.

15. During diffleult times I spend a lot of time alone with God.

16. I place the interests of other people ahead of myself.

17. I try to be filendly to people who don't have many eriends.

18. Attending church doesn't do much for ine.

19. I find little evidence that God has been gulding me.

20. I ofter hum, uhtstla nr sing Christian songs.

21. I seldom take t1me to reflect on God's blessings to me.

22. I seldom recelve answers to my prayers.

23. I enfoy sharing insights from my Blble study.

24. I experjence peace after I've conseseed my sins.

25. I regularly choose to be alone with God.

26. I'm very happy when others succeed.

27. I get annoyed with people who interrupt what I'n doing.
SA A U D SD

SA A U D SD

SA A O D SD

SA A U D S SD

SA A U D SD

SA A U D SD

SA A U D SD

SA A U D SD

SA A U D SD

SA A U D SD

SA A $D$ D SD

SA A U D SD

SA A O D S

SA A $U$ D SD

SA A O D SD

SA A U D SD 
28. During church worship I often feel God speaking to me.

29. I'm a very independent person so I don't need to depend on God.

30. Christianity makes me feel very happy.

31. I often meditate on Bible passages.

32. I have a special time of prayer at least once a day.

33. I study scripture so I can get to know Jesus better.

34. I'm very aware of my need of God's forgiveness.

35. I seldom sense God's presence.

3.6. I'm only nice to people if they're nice to me.

37. I don't mind istering when people want to talk about theit problems.

38. I feel God's presence during church worship.

39. I often seek guldance through the words of Scripture.

40. Christiandty helps me to be a reyy positive person.
SA A U D SD

SA A $U$ D

SA A U D SD

SA A U D SD

SA A O D SD

SA A $\quad$ U $\quad$ O $\quad$ SD

SA A U D SD

SA A U D SD

SA A U D SD

$S A$ A U D SD

SA A $U$ D $S D$

SA A U D SD

SA A O D SD 
1. The principal's actions in this school are often inconsistent with what Christiantty is all about.

2. Many teachers regard the religlous activities as unimportant interruptions in the school program.

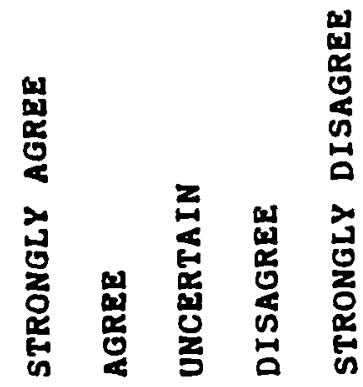

SA $\quad A \quad U \quad D \quad S D$

SA A $\quad$ U $\quad D \quad S D$

3. The teachers seldom encourage students who are having problems.

SA A U D SD

4. Discipline in this school is very Sair.

SA A U D SD

5. The teachers' actlons in this school are often inconsistent with what Christanity is all about.

6. Worshlps in this school are often guite boring.

7. Service/Outreach activities are a low prlority in this school.

SA A O D SD

SA $\quad$ A $\quad 0 \quad$ D $\quad$ SD

SA A U D SD

8. The Bible teacher's actions in this school are often inconsistent with

SA A O D SD what Christiantey is all about. 
9. Weeks of Prayer help make the Bible relevant.

10. Jesus Christ is usualiy the central

focus in Blble classes.

11. We seldom have morning or evening

worship in our home.

12. The principal has led me closer to Jesus.

13. Christian principles are usualiy applied to our extra-curficular activities.

14. The teachers respect differences in students.

15. Our teachers have a very negative approach to student behavior.

16. The teachers (apart from the Blble teacher) have led me closer to Jesus.

17. The Bible is always used in school worships .

18. The school schedule includes opportunities for service/outreach activities.

19. The Blble teecher has led me closer to Jesue.

20. Weoke of Prayer seldom talk about practlcal Christian living.

21. B1ble classes have helped me to better understand the meaning of life.

22. My parents seldom have their own prlvate dafly devotions.

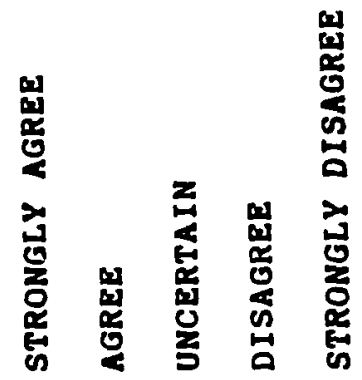

SA A U D SD

SA A U D SD

SA A O D SD

SA A U D SD

SA A $O$ D SD

SA A U D SD

SA A U D SD

SA A U D SD

SA A $O$ D SD

SA A U D SD

SA A U D SR

SA A U D SD

SA A U D SD

SA A U D SD 
23. The principal is a real spiritual leader in this school.

24. Jesus Christ is obviously the central focus of the educational program in this school.

25. The teachers seldom point oit the strengths of Christianity compared with secular soclety.

26. Many of our teachers don't trust the students.

27. The teachers (apart from the Bible teacher) seldom make reference to their own personal Bible study.

28. Students are often encouraged to participate in prayer groups during school worships.

29. Students are encouraged to give personal time towards service/ outreach projects.

30. I feel comfortable in sharing my troubles with the Blble teacher because he/she understands.

31. Weeks of Prayer have deepened my personal relationship with Jesus.

32. Bible classes have lead me into a closer relationship with Jesus.

33. My perents are actively involved in church activities.

34. The principal is rarely enthusiastic about his/her relationship with Jesus.

35. The readings in Inglish literature are consistent with the principles of Chrlstiant ty.
SA A U D SD

SA A $O$ D $\quad$ D $\quad$ SD

SA A $O$ D SD

SA A U D SD

SA A U D SD

SA A U D SD

SA A O D SD

SA A U D SD

SA A U D SD

SA A U D SD

SA A $O$ D $\quad$ SD

SA A U D SD

SA A U D SD 
36. Tha teachers seldom encourage students to help one another.

37. Students are often invited to participate in establishing the rules of this school.

38. The teachers usually artend school worships.

39. Students' concerns are seldom prayed for during school worships.

40. The school has a mission-outreach fund-raising project involving staff and students.

41. The Bible teacher is rarely enthusiastic about his/her relationship with Jesus.

42. Weeks of Prayer are often boring presentations of church doctrine.

43. Blble classes tell you how to live the Christian 11fe.

44. My parents seldom speak about theif relationship with Jesus.

45. The principal is very concerned about leading students into a personal relitionshlp with Jesus.

46. Bible study groups are rarely encouraged in this school.

47. The teachers include the Bible, where approprlate, in all the subjects they teach.

48. The teachers are very forgluling when dealing with students who have done wrong.

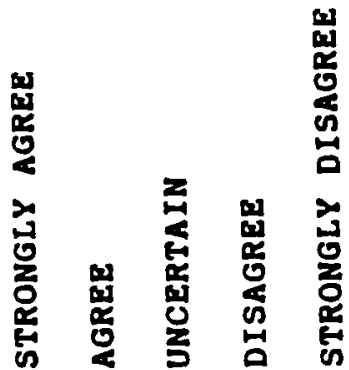

SA A U $\quad$ D $\quad$ SD

SA $\quad A \quad \cup \quad D \quad S D$

SA A O D $S D$

SA A O D SD

SA A U D SD

SA A O D SD

SA A U $\quad$ D $\quad$ SD

SA A U D SD

SA A U D SD

SA A U D SD

SA A U D SD

SA A U D SD

SA A U D SD 
49. The teachers are rarely enthusiastic about their relationship With Jesus.

50. School worshlps have lead me into a deeper relationship with Jesus.

51. The school rarely particlpates in communt ty-organtzed service projects.

32. The Bible teacher is very concerned about leading students into a personal relationship with Jesus.

53. Weeks of Prayer have helped to make Chr1stiandty relevant.

54. B1ble-study skills are often demonstrated during BIble classes.

55. My parents model the principles of Christiandty in their daliy lives.

56. Apart from the B1ble class, the Blble is seldom used in school.

37. The teachers usually commence classes with prayer.

58. School administrators don't respect the rights of students.

59. The teachers (apart from the Bible tencherl are very concerned about leading otudents into a personal relatlonship with Jesis.

60. My parents have taujht me to be faltheul in returning my tithe to God.
SA A U D SD

SA A O D SD

SA A O D SD

SA A U D SD

SA A $\quad$ O $\quad$ D $\quad$ SD

SA A U D SD

SA A U D SD

SA A $\quad$ U $\quad$ D $\quad$ SD

SA A O D SD

SA A U D SD

SA A U D SD

SA A U D SD 


\section{APPENDIX 4 \\ APPLICATION FOR APPROVAL OF PROPOSED USE OE HUMAN SUBJECTS AND \\ INEORMED CONSENT FORM}

Reproduced with permission of the copyright owner. Further reproduction prohibited without permission. 


\section{ANDREWS UNIVERSITY}

School of Education

APPLICATION FOR APPROVAL OF PROPOSED USE OF HUMAN SÜBJECTS

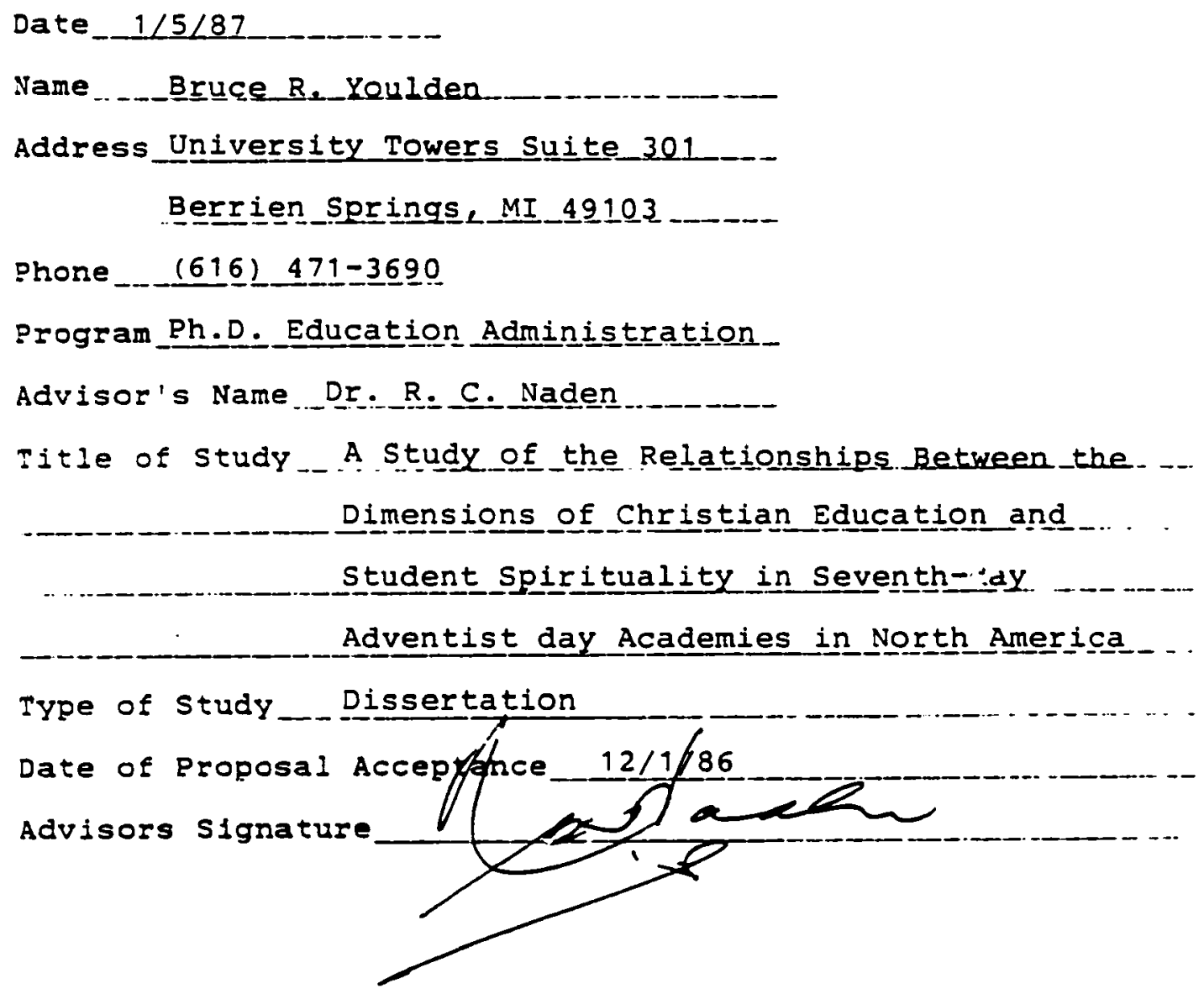




\section{INEORMED CONSENI FORM}

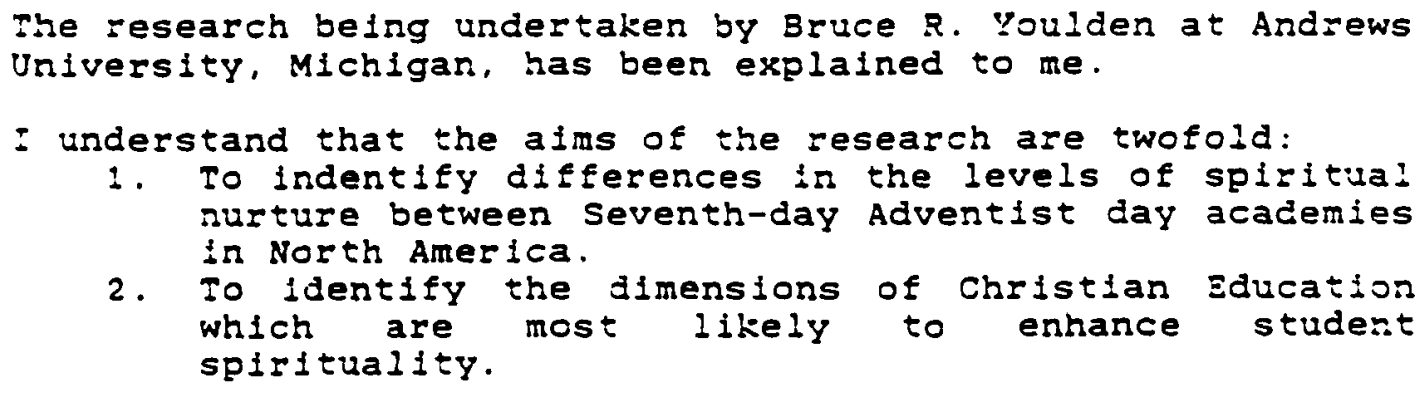

2. To identify the dimensions of Christian Education which are most likely to enhance student spirituality.

I further understand that:

$\therefore$ All information is confidential and my identity will not be known.

2. I am free to withdraw my consent and to discontinue my participation in the project at any time.

3. Any questions I have about the research will be answered.

On the basis of the above statements. I agree to participate in this research.

Participants signature

Däe

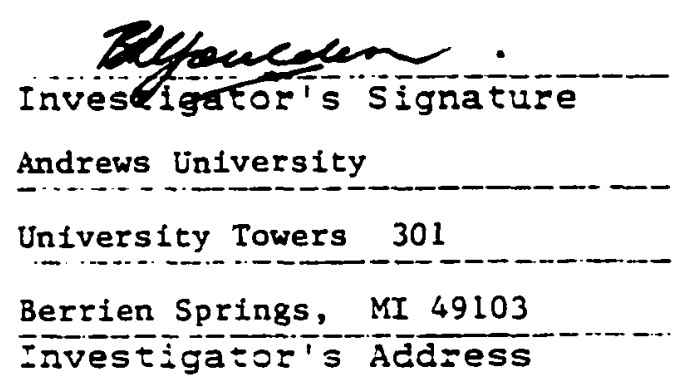


Akers, G. H., \& Moon, R. D. (1980, Summer). Integrating learning, faith, and practice in Christian education. Journal of Adventist Education, 42, i731 .

Alexander, C. (1981, May-Jun). Schools without faith. Religious Education, 76, 307-321.

Alexander, W. (1972, Eeb-Mar). Toward a community of the creator spirit. Journal of Adventist Education. 34, $16-17,28-29$.

Anne, J. (1980, February). Discovery in service. Momentum. pp. $22-25$.

Astley, J. (1984). The role of worship in Christian learning. Religlous Education, 29 (2), 243-251.

Augustine Confessions. (1909). In C. W. Eliot (Ed.). The Harvard Ciassics $i$. Naw York: Collier \& Son.

Axelrod, S. (1977). Behavior modification for the classroom teacher. New York, NY: McGraw-Hi11.

Barclay, W. (1973). The plain man's quide to ethics. Londo.r: Fontana Books.

Barrett, F. X. (1979, October). Spiritual preparation of teachers. Momentum, pp. 7-8.

Bartholomew, E. F. (1927). Blblical pedagogy. Rock Isjand, IL: Augustana Book Concern Pub.

Battenhouse, R. W. (Ed.). (1955). A companion to the study of St. Augustine. New York: Oxford Press.

Beechick, R. (1982). A biblical psychology of learning. Denver, CO: Accent Books.

Bennis, W., \& Nanus, B. (1985). Leaders: Strategies for taking charge. New York: Harper \& Row. 
Betts, G. H. (1910). How to teach religion: Principles and methods. New York: Abingdon Press.

Blackham, G., \& Silberman, A. (1975). Modification of child and adolescent behavior (2nd ed.). Belmont, CA: Wadsworth.

Blamires, H. (1963). The Christian mind: How should a Christian think. Ann Arbor, MI: Servant Books.

Bonhoeffer, D. (1954). Life together. (Intro. by J. W. Doberstein. Trans.). New York: Harper \& Brothers.

Bonhoeffer, D. (1959, 1963). The cost of discipleship (2nd ed.). (R. H. Fuller, Trans.). Foreword by

G. K. A. Bell. New York: Macmillan.

Booth, Walter M. (1975, Eeb-Mar). The fabric of a Christian's education. Journal of Adventist Education, 37, 23-24, 27 .

Bornstein, W. R. (1982, October 7). A week of prayer. Messenger, p. 3 .

Bounds, E. M. (1966). Power through prayer. Chicago: Moody Press.

Bower, R. S. (1985, Oct-Nov). Weeks of spiritual emphasis. Journal of Adventist Education, 48, 22, 37-38.

Braley. J. W. (1978). The Christian philosophy applied to methods of instruction. In $P$. A. Kienel (Ed.), The philosophy of Christian school education. Whittier, CA: Assoc. of Christian Schools Int.

Bresee, F. (1978, Apr-May). How to handle the rascals. Journal of Advent1st Education, 40, 2, 5-7.

Bresee, F. (1978, Summer). Rules or principles. Journal of Adventist Education, 40, 16, 25.

Brophy, J. (1977). Child development and socizlization. uhicago: Sclence Research Associates.

Brophy, J., \& Putman, J. (1979). Classroom management in the elementary grades. In D. Duke (Ed.), Classroom management. Chicago: University of Chicago Press.

Brown, V. (1983/1984, Dec-Jan). Bible class: More than studying for a test. Journal of Adventist Education, 46, 16, 43-44. 
Buckley, F. J. (1977, October). Toward a theology of teaching ministry. Momentum. p. 4-9.

Buechner, F. (1973). Wishful thinking. San Francisco: Harper and Row.

Burns, J. M. (1978). Leadersh1p. New York: Harper \& Row.

Bushnell, H. (1947). Christian nurture. New Haven: Yale University Press.

Byrne, H. W. (1977). A Christian approach to education: educational theory and practice. Grand Rapids, MI: Zondervan.

Calvin, J. (1952). In H. J. Van Andel (Ed.), Golden bookiet of the true Christian 1ife. Grand Rapids, MI: Baker Book House.

Canter, I. (1982). Assertive discipline for parents. Santa Monica, CA: Harper \& Row.

Carey, L. (1977, October). Redefining the ministry of teaching: Service to the global community. Momentum, Pp. 17-20.

Chadwick, R. P. (1982). Teaching and learning: An integrated approach to Christian education. old Tappan, NJ: Fleming $H$. Revel.

Cooper, A. (1982, October). Disciplinary principles for the grincinal. The Christian Educator's Journal, pp. 24-25.

Cumnings, D. B. (Ed.). (1979). The purpose of a Christian school. Phillipsburg, $\overline{\mathrm{NJ}}$ : Presbyterian and Reformed Pub.

Cunningham, L. L., \& Gephart, W. J. (Eds.). (1973). Leadership: The sclence and the art today. Itasca, IL: Peacock Pub.

Devnich, D. D. (1981, Apr-May). Christ-centered religious life activities. Journal of Adventist Education, $43,7-9,40-42$.

Dobson, J. (1970). Dare to discipline. Wheaton, IL: Tyndale House.

Dostoevsk1, F. (1952). The brothers Karamazov. Chicago, IL : Encyclopedia Britannica, Great Books. 
Douglas, W. (1978/1979, Dec-Jan). Teaching theology in SDA academies. Journal of Adventist Education, 41, 8-9, 46 .

Dudley, R. L. (1978). Why teenagers reject religion: And what to do about it. Washington, DC: Review and Herald Pub.

Dudley, R. L. (1979, Summer). Alienation from religion in Adventist teenagers. Journal of Adventist Education, 41, 5-7, 47.

Dudley, R. L. (1981/1982, Dec-Jan). Competition and cooperation in the classroom: Which goal structure is more effective? Journal of Adventist Education. 44. 34-35, 37-38.

Dudley, R. I. (1983/1984, Dec/Jan). Beyond Bible facts. Journal of Adventist Education, 46. 3 .

Dunbebin, C. \& stull, R. (1983, Apr-May). Three-level behavior code produces results. Journal of Adventist Education, 45, 8-10, 42 .

Eavey, C. B. (1964). Aims and objectives of Christian education. In J. Edward Hakes (Ed.), An introduction to evangelical Christian education. Chicago, IL: Moody Press.

Edge, F. B. (1959), Helping the teacher. Nashville, TN: Broadman.

English, P. (1977, November). A Christian perspective on classroom and school discipline. Journal of Christian Education. 15-16, 14-23.

Engstrom, T. W. (1983). Your gift of administration: How to discover and use it. Nashville, TN: Thomas Nelson.

Ernst, K. (1972). Games students play. Millbrae, CA: Celestial Arts Pub.

Fairchild, C. (1985, Oct-Nov). Morning worship--the best time of the day. Journal of Adventist Education. 48, $11-13,38-39$.

Fakkema, M. (1952). Christian philosophy: Its educational implications. Chicago, IL: The National Assoc. of Christian Schools.

Fearing, A. C. (1952, October). Week of prayer in acadeny. Ministry, pp. 21-22. 
Feistritzer, P. (1976, February). Mother Teresa: A joyful servant. Momentum, pp. 26-30.

Ferre, N. F. S. (1951). Strengthening the spiritual life. New York: Harper \& Brothers.

Flynn, M. (1985). The effectiveness of Catholic schools. Sydney, Australia: st. Paul Pub.

Foster, Z. H. (1973/1974, Dec-Jan). Classroom control--A shared responsiblity. Journal of Adventist Education, 36, 10-11.

Foster, R. J. (1978). Celebration of discipline: The path to spiritual growth. San Francisco, CA: Harper \& Row.

Fowler, J. W. (1981). Stages of falth: The psychology of human deve lopment and the quest for meaning. San Francisco, CA: Harper \& Row.

Fox, G. (1952). The journal of George Eox (rev. ed. by J. L. N1ckalls). London: Cambridge University Press.

Francis of Assisi. (1964). The writings of St. Francis of Assisi (Benen Fahy, Trans.). Intro. and notes by Placld Hermann. Chicago: Eranciscan Herald Eress.

Freed, A. (1973). TA for kids and grown-ups too. Los Angeles: Jalmar Press.

Gaebelein, F. E. (1964). Toward a philosophy of Christian education. In Edward Hakes (Ed.), An introduction to evangelical Christian education. Chicago: Moody Press.

Gaebele1n, F. E. (1968). The pattern of God's truth: The integration of faith and learning. Chicago: Moody Press.

Gage N. L., \& Berliner, D. C. (1984). Educational psychology (3rd ed.). Boston: Houghton Miffin.

Gallagher, E. (1982, Eeb-Mar). Religlous potential: Can we expect spirituality in our students? Journal of Adventist Education, 44, 34, 39 .

Gangel, K. O., \& Benson, W. S. (1983). Christian education: Its history and philosophy. Chicago: Moody Press.

Gardner, J. W. (1963). Self-renewal. New York: Harper \& Row. 
Geisler, N. L. (Ed.). (1982). What Auqustine says. Grand Rapids. MI: Baker Book touse.

Gillespie, B. (1973/1974, Dec-Jan), Values are for people. Journal of Advenist Education, 36, 6-7, 31 .

Glasser, W. (1969). Schools without fallure. New York: Harper \& Row.

Gobbel. A. R.. E cobbel, G. G. (1379, Nov̈-Deci. Cinjiaren in worship. Reilgious Education, $74(6), 571-582$.

Gordon, T. (1975). Teacher effectiveness training. New York: Peter $H$. Wyden.

Graendorf, W. C. (Ed.). (1981). Introduction to biblical Christian education. Chicago: Moody Press.

Graham, M. S. (1983, Apr-May). Differences in discipline. Journal of Adventist Education, 45, 18-19.

Greenleaf, R. K. (1977). Servant leadership: A fourney into the nature of legitimate power and greatness. New York: Paulist Press.

Grissen, L. V. (1981/82, Dec-Jan). Christian education: For such a time as this. Christian Educators Journal. pp. 4-5.

Groome, T. H. (1981, Sept-oct). Conversion, nurture and educators. Journal of Religious Education, 76 (5), 482-496.

Haburn, W. B. (1981). Methods of teaching. In Werner G. Graendorf (Ed.). Introduction to biblical Christian education. Chicago, IL: Moody Press.

Hamilton, M. C. (1976, Apr-May). Using love to modify behavior. Journal of Adventist Education, 38, 2425,30 .

Hamm111, R. (1982, Oct-Nov). Educational leadership. Journal of Adventist Education, 45, 13, 43.

Harkness, G., Steere, D. V., \& Tittle, E. F. (1953). The religious life. Hazen Book Classics. New York: Association Press.

Hartman, H. C. (1952, October). Preparing for the week of prayer. Ministry, pp. 28-30. 
Hay, D. (1983, Summer). Suspicion of the spiritual: Teaching religion in a world of secular experience. British Journal of Religious Education, pp. 140147)

Hermann, P. (1964). The way of St. Erancis. Chicago: Franciscan Herald Press.

Heyboer, S. (1980, Oct-Nov). Christian schools and the challenge of witnessing. The Christian Educators Journal, pp. 25-26.

Hilde, R. L. (1976). The rod vs the m\&m's. Mountain View, CA: Pacific Press.

Hilde, R. L. (1978/1979, Dec-Jan, Feb-Mar). An introduction to the teaching principles of Jesus. Journal of Adventist Education, 41, Pt. I 17-32; Pt. II 17-31.

Hill, B. (1982). Faith at the blackboard: Issues facing the Christian teacher. Grand Rapids, MI: Eerdmans.

Hillerbrand, H. J. (Ed.). (1974). Luther's works (Vols. 42, 43, 51, 52). Philadelphia, PA: Fortress press.

Hirst, P. H. (1967). Public and private values and religious educational content. In Theodore $R$. Sizer (Ed.). Religion and Public Education. Boston: Houghton Mifflin.

Hirst, P. H. (1974). Moral education in a secular society. London: University of London Press.

Holmes, A. F. (1975). The idea of a Christian college. Grand Rapids, MI: Eerdmans.

Holmes III, U. T. (1980). A history of Christian soirituality: An analytical introduction. New York: Seabury Press.

Homme, L. (1970). How to use contingency contracting in your classroom. Champaign, IL: Research Press.

Hudson, W. D. (1973). Is religious education possible? In Glen Langford and D. J. O'Connor (Eds.). New Essays in the Philosophy of Education. London: Routlege and Kegan Pauj.

Hurley, M. J. (1966). The declaration on Christian education of vatican Council II: Commentary. Glen Rock, NJ: Paulist Press. 
Hurlock, E. B. (1980). Developmental psychology: A life span approach (5th ed.). New York: McGraw-Hill.

Jaqua, C. L. (1979, Eeb-Mar). The Adventist educational leader. Journal of Adventist Education, 41, 5-6, 43 .

Jeffrey, D. L. (Ed.). (1987). A burning and a shining light: English spirituality in the age of Wesley. Grand Rapids, MI: Eerdmans.

Johnson, D. W., \& Johnson, R. T. (1974, Spring). Instructional goal structure: Cooperative, competitive, or individualistic. Review of Educational Research. 44, 213.

Johnson, D. W. , \& Johnson, R. T. (1975). Learning together and alone - cooperation, competition, and individualization. Englewood CI iffs, NJ: Prentice Hall.

Judd, W. (1986, Apr-May). The alienation of Adventist youth from religion. Journal of Adventist Eduestion. 48 . $18-19,45-47$.

Kainer, G. (1984, Oct-Nov). Tips for better Bible teaching. Journal of Adventist Education, 47, 12-13, 35-36.

Kelly, E. A. (1978). Preparing secondary school administrators: Changes are needed. Anaheim Convention of NASSP.

Kelly, T. A. (1957). A testament of devotion. London: Hodder and stoughton.

Kempis, T. A. (1949). The imitation of Christ. In Charles w. Eliot (Ed.). The Harvard Classics 7. New York: Collier \& Son.

Khan, S. B.. Weiss, J. (1973). The teaching of affective responses. In R. M. W. Travers (Ed.), Second Handbook of Research on Teaching. Chicago: Rand McNally.

Kienel P. A. (Ed.). (1978). The philosophy of Christiar. school education. Whittier, CA: Assoc. of Chirstian Schools Int.

Kiericegaard, S. (1940). Christian discourses (Walter Lowie. Trans.) Eair Lawn, NJ: Oxford University Press.

Knight, G. R. (1977, Oct-Nov). Redemptive discipline Journal of Adventist Education, 40, 5-6, 23. 
Knight, G. R. (1980), Philosophy and education: An introduction in Christian perspective. Berrien Springs, MI: Andrews University Press.

Knight, G. R. (1980/1981, Dec-Jan). Teaching the art of loving God's children. Journal of Adventist Education, 43, 34-35, 43.

Knittle, F. A. (1981, Oct-Nov). Christ in the classroum. Journal of Adventist Education, 44, 5-6, 41-43.

Kranendonk, D. L. (1978). Christian day schools, why and how. Ontario, Canada: Paideia Press.

Lall, B. M., \& Lall, G. R. (1979). Dynamic leadership. Mountain view, CA: Pacific Press.

Lawrence, Brother. (1982). The practice of the presence of God. Springvale, PA: Whitaker House.

Lee, L. L. (1976, Feb-Mar). Guiding student behavior in the Christian classroom. Journal of Adventist Education, 38, 18-19, 39.

Lepper, M. R. \& Greene, D. (1975). Turning play into work: Effects of adult surveillance and extrinsic rewards on children's intrinsic motivation. Journal of Personality and soclal Psychology, 31. 479-488.

Lewis, C. S. (1952). Mere christianity. New York: Macmilian.

Lewis, C. S. $(1958 / 1986)$. Reflections of the Psalms. New York: Harcourt Brace Jovanovich.

Ligouri, Alphonsus. St. (1964). To any Christian. London: Burns and Oats.

Link, M., \& Richards, L. (1982, Sept-Oct). The teacher as interpreter of the Bible. Religious Education. 17. 508-519.

LLoyd, M. A. (1985). Adolescence. New York: Harper \& Row.

Loveless, W. (1984, Feb-Mar). Should the college president be a spiritual leader. Journal of Adventist Education, 46, 10-11, 45-46.

Lucas. T. (1952, October). Missionary volunteer week of prayer. Ministry, pp. 17-19.

Manspeaker, B. L. (1985, Oct-Nov). Did I do all I could? Journal of Adventist Education, 48, 5-7, 42-45. 
Massey. J. E. (1985). Spiritual disciplines. Grand Rapids, MI: Zondervan.

Maxwell, G. A. (1952, October). Follow-up for the week of prayer. Ministry, pp. 30-31.

McBride, A. (1976, February). Should everyone teach religion? Momentum, pp. 31-34.

McDermott, E. J. (1975, February). The principal as religious leader. Momentum, p. 49.

McGinn, B. \& Meyendorff, J. (Ed.). (1985). Christian spirituality 16: Origins to the Twelfth Century. New York: Cross Road Pub.

Merton, I. T. (1960). Spiritual direction and meditation. Collegeville, MN: The Liturgical Press.

Merton, I. T. (1964). Life and Holiness. Garden City, NY: Image Books, Doubleday \& Co.

Merton, I. T. (1969). Contemplative Prayer. Foreword by Douglas $V$. Steere. New York: Herder and Herder.

Morgan, D. H. (1986, Summer). Interaction, service, and outreach: A unlque curriculum proposal for Adventist secondary schools. Journal of Adventist Education, 48, 16-17, 36-37.

Morphet, E. L., Johns, R. L., \& Reller, T. L. (1982). Educational organization and administration (4th Ed.). Englewood Cliffs, NJ: Prentice-Hall.

Moustakas, C. (1972). The authentic leader. Cambridge, MA: Doyle.

Murray, W. E. (1958, November 6). Preparing for the week of prayer. Review and Herald, pp. 10-11, 44-45.

Neill, A. S. (1960). Summerhill: A radical approach to child rearing. New York: Hart Pub.

Nouwen, H. J. M. (1975), Reaching out: The three movements of the spiritual life. Garden City, NY: Dolibleday.

Nouwen, H. J. M. (1979). The wounded healer: Ministry in contempory soclety. Garden City, NY: Doubleday.

Nouwen, H. J. M. (1982). Making all things new: An invitation to the spiritual life. San Francisco: Harper \& Row. 
Ochs, W. B. (1953, October 15). Our call to prayer. Review and Herald, pp. 20-21.

O'Dea, T. F. (1966). The soclology of religion. Englewood Cliffs, NJ: Prentice Hall.

olson. A. V. (1952, October). Week of prayer in the church. Ministry, p. 16 .

0lson, A. V. (1955, November 10). Why attend week of prayer? Review and Herald pp. 12-13, 29.

ott. H. K. (1978, Oct-Nov). The role of religion in education. Journal of Adventist Education, 41, 20$21,26$.

ozment, R. V. (1956). Conversion in Christian education and revivalism. Doctoral Dissertation, Boston University Graduate School.

Parrilla, L. (1973, Oct-Nov). Teach values or else. Journal of Adventist Education, $36,8-9,28$.

Patt, J. M. (1975, Apr-May). Character building in our youth. Journal of Adventist Education, 37, 5-7, 30.

Peterson, G. A. (1981). The Christian teacher. In Werner C. Graendorf (Ed.). Introduction to biblical Christian education. Chicago, IL: Moody Press.

Pittman, T. S., Bogglano, A.K., \& Ruble, D. N. (1982). Intrinsic and extrinsic motivational orientations: Interactive effects of reward, competence feedback and task orientation. In J. M. Levine \& $M$. C. Wang (Eds.). Teacher and student perceptions. Hinsdale, NY: Lawrence Erlbaum.

Presthus, R. (1962). The organizational society. New York: Alfred A. Knopf.

Priester, M. J. (1966). The philosophical foundations for Christian education. In $M$. J. Taylor(Ed.), An introduction to Christian education. Nashville, TN : Abingdon Press.

Rafferty, M. (1970). Summerhil1: For and against. New York: Hart Pub.

Rebok, D. E. (1947, December 4). Southern Missionary College's iveek of prayer. Review and Herald, p. 19. 


$$
210
$$

Reck, C. (1979, October). What's Catholic about Catholic schools? Momentum, p. 45-49.

Richards, L. O. (1975). A theology of Christian education. Grand Rapids, MI: Zondervan.

Rogers, C. (1969). Freedom to learn: A view of what education might become. Columbus, OH: Charles $E$. Merril1.

Rumer, R. E. (1967). The spiritual nature of the learning person and the process of spiritual learning: The crucial elements in the theory that christian education is spiritual nurture. Doctoral dissertation, Pacific school of Religion.

Saliers D. E. (1984). Worship and spirituality. Philadelphia, PA: Westminster Press.

Sanders, J. O. (1980). Spiritual leadership (rev. ed.). Chicago: Moody Press.

Sanderson, J., Jr. (1979). Pupil. In David B. Cummings (Ed.), The purpose of a Christian school. Phillipsburg, NJ: Presbyterian and Reformed Pub.

Sanner, A. E., \& Harper, A. F. (Eds.). (1978). Exploring Chilstian education. Kansas City: Beacon Hill Press.

Schulman, M. \& Mekler, E. (1985). Bringing up a moral child. Reading: MA: Addisoñ-Wesiey Pub.

Scott. D. (1985). Philosophy of Christian education. Denver, Co: Conservative Baptist Theological Seminary Press.

Schaeffer, F. (1972). True spirituality. London: Hodder and Stoughton.

Shelton, C. M. (1983). Adolescent spirituality: Pastoral ministry for high school and college youth. Chicago: Loyola University Press.

Shields, K. M. (1974, December). A new day for religion teachers. Momentum, pp. 17-21.

Shultz, M. W. (1972/1973, Dec-Jan, Feb-Mar). A systems approach to discipline. Journal of Adventist Education, 35, Pt.1. 5-7: Pt.2, 28-29.

Slattery, P. J. (1974, Nov-Dec). The religion teacher in the classroom. Reliqious Education, 69, 665-679. 
Smith, H. W. (1970). The Christian's secret of a happy

life. Old Tappan, NJ: Fleming $H$. Revel.

Spurgeon, C. H. (1981). 12 sermons on repentance. Grand Rapids, MI : Baker Book House.

Spurgeon, C. H. (1982). 12 sermons on praise. Grand Rapids, MI : Baker Book House.

Stanley, C. (1985). How to listen to God. Nashville, TN: Thomas Nelson Pub.

Stanwood, P. G. (Ed.). (1978). The classics of western Spirituality: William Law. New York: Paulist Press.

Steere, D. V. (Ed.). (1984). The classics of Christian spirituality: Quaker spirituality, selected writings. New York: Paulist Press.

Stone, D. J. (1985). Spiritual growth in youth ministry. Loveland, CO: Group Books.

Suddarth, B. H. (1985, May 1). Weeks of prayer revive spiritual energies. Visitor, p. 7 .

Taylor, J. (1930). Holy living and dying. London: Longmans.

Taylor, J. (1957). The rule and exercises of holy living in fellowship of the saints: an anthology of Christian devotional literature. New York: Abing-Cokesbury Press.

Temple, w. (1920). Fellowship with God. London: Macmillan Pub.

Thayer, J. D. (1983, Oct-Nov). Is your grading system fair --and defensible? Journal of Adventist Education. 46, $14-15,37-38$.

Thiessen, E. J. (1985, Jan-Feb). A defense of a distinctively Christian education. Religious Education, 3, 7-50.

Tournier, P. (1962). Guilt and grace. San Francisco: Harper \& Row.

Tournier, P. (1976). Reflections. Philadelphia, PA: Westminster press.

Tuls, A. Jr. (1981, Apr-May). Teaching outside the classroom. Christian Educators Journal, pp. 24-25. 
Underhill, E. (1937). The soiritual life. Msw York: Harper \& Row.

Underhill, E. (1963). Concerning the inner ife, with the house of the soul. London: Methuen \& Co.

Unknown Christian. (1971). The kneeling Christian. Grand Rapids, MI: Zondervan.

Vandeman, G. E. (1952, October). The college week of prayer. Ministry, pp. 19-21.

Voskuil, I. I. (1982, October). Nurturing social concern. The Christian Educators Journal, pp. 12-14.

Walworth, W. (1981). Educational curriculum. In W. G. Greandorf (Ed.), Introduction to biblical Christian education. Chicago, IL: Moody Press.

Watts, I. (1987). On prayer. In D. L. Jeffrey (Ed.), A burning and a shining light. Grand Rapids, $M \bar{I}$ : Eerdmans.

Wear, E. (1980/1981, Dec-Jan). Learning theories and the Christian teacher. Journal of Adventist Education, 43. 17-32.

Wesley, J. (1938). The fournal of the Reverend John Wesley. London: Epworth Press.

Wessler, M. F. (1979/1980, Dec-Jan). The distinctive character of church-related schools. Headmaster U.S.A., PP. 5-7.

White, E. G. (1905). Ministry of healing. Washington, DC: Review and Herald Pub.

:H1te, E. G. (1916). Gospel workers. Washington, DC: Review and Herald Pub.

White, E. G. (1923). Fundamentals of Christian education. Nashville, TN: Southern Rub.

White, E. G. (1930). Messages to young people. Nashville, TN : Southern Pub.

White, E. G. (1943). Prophets and kings. Mountain View, CA: Pacific Press

White, E. G. (1943). Counsels to parents, teachers, and students. Mountain View, CA: Pacific Press. 


\section{3}

White, E. G. (1948). Testimonies to the church. 9 Vols. Mountain View, CA: Pacific Press.

White, E. G. (1952). Education. Mountain View, CA: Pacific Press.

White, E. G. (1953). Desire of ages. Mountain View, CA: Pacific Press.

White, E. G. (1955). Sons and daughters of God. Washington, DC: Review and Herald Pub.

White, E. G. (1956). Steps to Christ. Mountain View, CA: Pacific press.

White, E. G. (1976). Counsels on diets and foods. Washington, DC: Review and Herald Pub.

Whitefield, G. (1987). Sermons: The almost Christian. In D. L. Jeffrey (Ed.), A burning and a shining light. Grand Rapids, MI: Eerdmans Pub.

Wood, C. L., Nicholson, E. W., \& Eindley, D. G. (1979). The secondary school principal: Manager and supervisor. Boston: Allyn \& Bacon.

Zais, R. S. (1976). Curriculum: principles and foundations. New York: Harper \& Row.

Zuck, R. B. (1963). Spiritual power in your teaching. Wheaton, IL: Scripture Press. 
CURRICULUM VITAE

\section{PERSONAL DATA}
Name :
Bruce R. Youlden
Date of Birth:
27 August 1953
Place of Birth: Melbourne, Australia

\section{EDUCATION :}

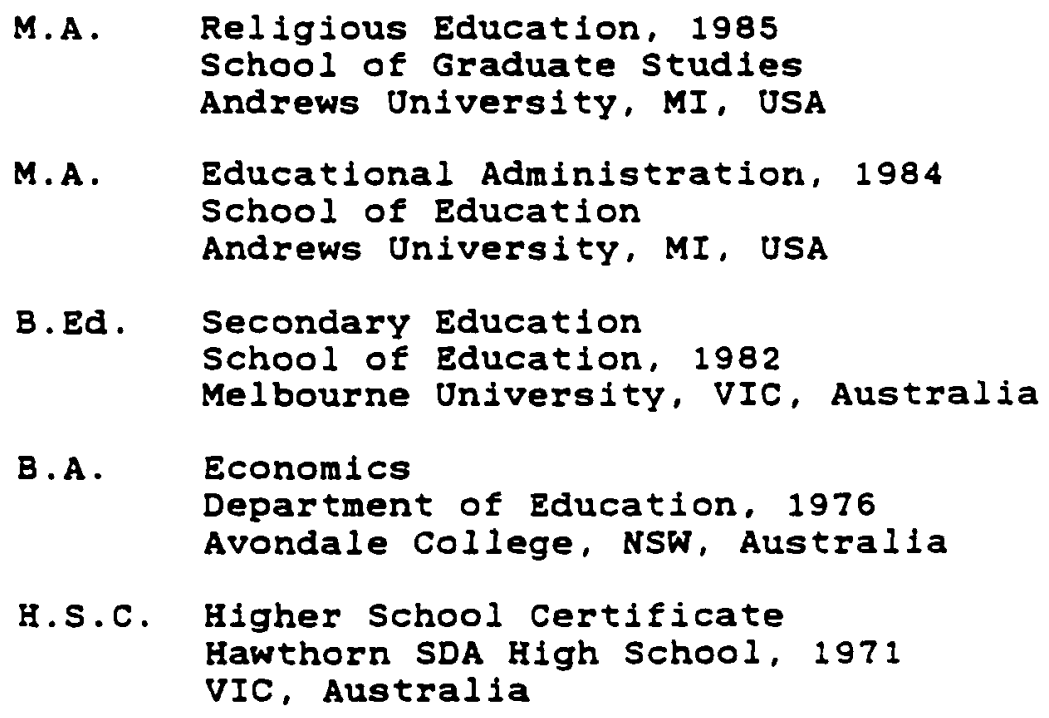

\section{PROFESSIONAL EXPERIENCE :}

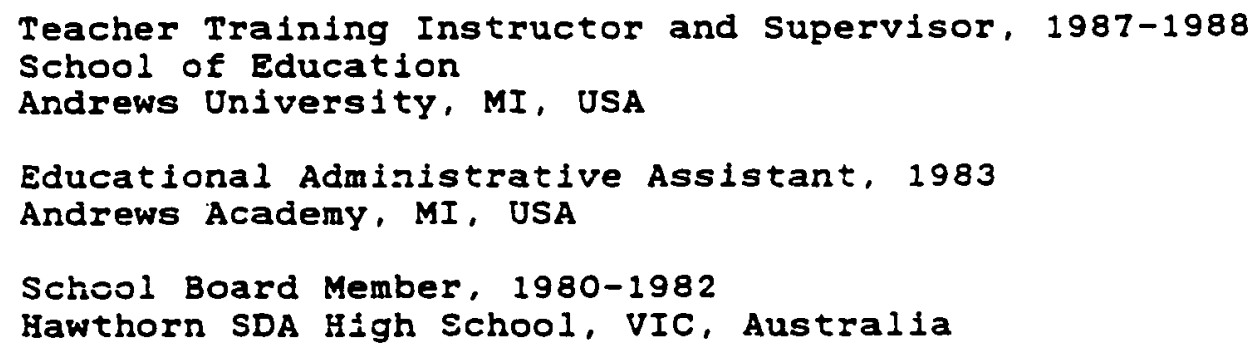


Economics and Religion Instructor, 1977-1982

Hawthorn SDA High School, VIC, Australia

Music and Concert Tour Director, 1978-1982

Hawthorn SDA High School, VIC, Australia

Sports and Fhysical Education Coordinator, 1978-1982

Hawthorn SDA High School, VIC, Australia

Assistant Dean of Men, 1976

Avondale College, NSW, Australia 